\title{
On several new or poorly-known Oriental Paradoxosomatidae (Diplopoda: Polydesmida), XVII
}

\section{О несколыких новых или плохоизученных ориенталыных Paradoxosomatidae (Diplopoda: Polydesmida), XVII}

\author{
S.I. Golovatch \\ С.И. Головач
}

Institute for Problems of Ecology and Evolution, Russian Academy of Sciences, Leninsky prospekt 33, Moscow 119071 Russia. E-mail: sgolovatch@yandex.ru

Институт проблем экологии и эволюции РАН, Ленинский проспект, 33, Москва 119071 Россия.

KEY WORDS: Diplopoda, Polydesmida, Paradoxosomatidae, taxonomy, new records, new genus, new species, new synonymy, new combination, key, Nepal, Bangladesh, Cambodia, Vietnam.

КЛЮЧЕВЫЕ СЛОВА: Diplopoda, Polydesmida, Paradoxosomatidae, таксономия, новые находки, новый род, новые виды, новая синонимика, новая комбинация, ключ, Непал, Бангладеш, Камбоджа, Вьетнам.

ABSTRACT. This contribution is devoted to new records of a few known, and to descriptions of the following 16 new, Oriental species: Anoplodesmus magnus sp.n., Kronopolites coriaceus sp.n., Beronodesmus minutus sp.n., B. gorkhalis sp.n., B. longispinus sp.n., B. latispinosus sp.n., B. curtispinus sp.n., B. sinuatospinus sp.n., B. distospinosus sp.n., Delarthrum curtisoma sp.n., $D$. gracile sp.n., D. planifemur sp.n. and $D$. densesetosum sp.n., all from Nepal. Beronodesmoides gen.n., a new genus of the tribe Chamberliniini close to Beronodesmus Golovatch, 2014, is proposed for three new species from Nepal: $B$. anteriporus sp.n. (the typespecies), B. lobatus sp.n. and B. bifidus sp.n. Keys are given to all eight and three species of Beronodesmus and Beronodesmoides gen.n., respectively. The hitherto monobasic Dasypharkis Attems, 1936 is here considered as a new junior subjective synonym of Delarthrum Attems, 1936, syn.n., with Delarthrum rugulosum (Carl, 1932), from southern India, representing a comb.n. ex Dasypharkis.

РЕЗЮМЕ. Данное сообщение посвящено находкам нескольких известных, а также описаниям следующих 16 новых ориентальных видов: Anoplodesmus magnus sp.n., Kronopolites coriaceus sp.n., Beronodesmus minutus sp.n., B. gorkhalis sp.n., B. longispinus sp.n., B. latispinosus sp.n., B. curtispinus sp.n., B. sinuatospinus sp.n., B. distospinosus sp.n., Delarthrum curtisoma sp.n., D. gracile sp.n., D. planifemur sp.n. и $D$. densesetosum sp.n., все из Непала. Предложен новый, близкий к Beronodesmus Golovatch, 2014 род Beronodesmoides gen.n. из трибы Chamberliniini для трех видов из Непала: $B$. anteriporus sp.n. (типовой вид), B. lobatus sp.n. и B. bifidus sp.n. Даны ключи соответственно для всех восьми и трех ви-

Results of the Himalaya Expeditions of J. Martens. No.282.- For No.281 see: Vertebrate Zoology 65(1), 2015. дов родов Beronodesmus и Beronodesmoides gen.n. До сих пор монотипический род Dasypharkis Attems, 1936 считается новым младшим субъективным синонимом Delarthrum Attems, 1936, syn.n., а вид Delarthrum rugulosum (Carl, 1932) из Южной Индии представляющим comb.n. ex Dasypharkis.

\section{Introduction}

This paper is devoted to new records of several known, as well as to descriptions of 16 new, species of paradoxosomatid millipedes, mainly from Nepal.

\section{Material and methods}

Most of the material belongs, and has been returned, to the collection of the Natur-Museum Senckenberg (SMF), Frankfurt a.M., Germany, with only very few duplicates retained for the holdings of the Zoological Museum, Moscow State University, Russia (ZMUM + entry number) and the Natural History Museum of Denmark (Zoological Museum), Copenhagen, Denmark (ZMUC), as indicated below.

Pictures of two species were received for comparative purposes from the Naturhistorisches Museum Wien (NHMW), Austria.

\section{Taxonomic part}

Desmoxytes cervaria (Attems, 1953)

MATERIAL. $1 \sigma^{7}$ (ZMUM 02375$)$, Vietnam, Laocai Prov., near Sapa, $22.3866^{\circ} \mathrm{N}, 103.7868^{\circ} \mathrm{E}, 23.05 .2014$, leg. A.L. Ozerov.

REMARKS. Because this species has hitherto been known only from Sapa and the neighbouring Mt Fanxipan [Attems, 1953], the above sample represents a strict topotype. This species has recently been redescribed from type material [Likhitrakarn et al., 2015b]. 


\section{Hirtodrepanum latigonopum Golovatch, 1994}

MATERIAL. $100^{\top} \sigma^{7}, 4$ 우 (SMF), $20^{\top} \sigma^{\top}, 1$ (ZMUM $\rho 2383$ ), $1 \sigma^{7}$ (ZMUC), Nepal, Mustang Distr., banks of Lethe Khola near Lethe, $2400 \mathrm{~m}$ a.s.1., 5.07.1995, leg. J. Martens \& W. Schawaller.

REMARKS. This species has hitherto been known from several localities in central Nepal, including a few from Mustang District [Golovatch, 1994b]. So the above new samples can be regarded as near-topotypes.

\section{Streptogonopus phipsoni (Pocock, 1892)} Figs 1-4.

MATERIAL. $1 \sigma^{7}$ (ZMUM $\left.\rho 2574\right)$, Bangladesh, left bank of Ganges River, $24.068154^{\circ} \mathrm{N}, 89.045497^{\circ} \mathrm{E}$, upper terrace, grazed meadows, pitfall traps, 27.08.2014, leg. P.M. Glazov; $1 \bigcirc^{7}, 2$ 우, 7 juv. (SMF), $1 \sigma^{7}, 1$ क (ZMUM 22575 ), Nepal, Panchthar Distr., upper reaches of Mai Majuwa Khola, Dhorpar Kharka, 2700 m a.s.1., 27-28.08.1983, leg. J. Martens \& B. Daams.

REMARKS. This species has hitherto been known from several places in India and Pakistan [Attems, 1936, 1937; Shelley, 2014], thus being new to the faunas of both Bangladesh and Nepal. The above new samples agree in most details with the descriptions by Attems [1936, 1937], as well as with the key by Jeekel [1956], especially as regards the laterally clearly bordered collum and the caudally sharp and dentiform pleurosternal carinae (vs brim-like and caudally rounded, respectively, in the closest $S$. nitens Attems, 1936). Figs $1 \& 2$ are provided for comparative purposes to show the distinctions between these species, based on NHMW material. While the S. phipsoni sample from NHMW shows an evident pattern of much lighter caudal halves of metaterga (Fig. 1), the $S$. nitens syntype (Fig. 2), as well as the S. phipsoni specimen from Bangladesh are monochrome brown to dark brown, respectively, devoid of a clear-cut pattern, except for lighter caudal halves of paraterga. A pattern, mostly quite indistinct, is sometimes traceable also in the Nepalese specimens (Fig. 3), again primarily concerning lighter caudal halves of paraterga. The other somatic and all gonopod characters (Figs 3 \& 4), however, leave no doubt of the true species identity.

This species seems to be largely confined to grasslands [e.g. Bhakat, 1987].

\section{Helicorthomorpha luzoniensis (Peters, 1864)}

MATERIAL. $1 \sigma^{7}$ (ZMUM 02576$)$, Cambodia, Kep Prov., near Kep, $10^{\circ} 30^{\prime} 04.4^{\prime \prime} \mathrm{N}, 104^{\circ} 18^{\prime} 26.0^{\prime \prime} \mathrm{E}$, ca $120 \mathrm{~m}$ a.s.1., 8.06.2014, leg. I. Melnik.

REMARKS. This species, a senior synonym of $H$. orthogona (Silvestri, 1898), known so far from the Philippines, Indonesia, including New Guinea, and China [Jeekel, 2009; Golovatch \& Stoev, 2013], is new to the fauna of Cambodia.

\section{Delarthrum uncum (Golovatch, 1996)}

MATERIAL. $1 \sigma^{7}, 1$, 1 juv. (SMF), Nepal, Panchthar Distr., Paniporua, $2300 \mathrm{~m}$ a.s.1., mixed broadleaved forest, 16-20.04.1988, leg. J. Martens \& W. Schawaller.
REMARKS. This species has been described from several localities in the eastermost parts of Nepal, near the border to Sikkim, India [Golovatch, 1996]. The new samples can thus be regarded as near-topotypes.

\section{Delarthrum hirsutum (Golovatch, 1994)} Fig. 5.

MATERIAL. $1 \sigma^{\top}$ (SMF), Nepal, Myagdi Distr., Myagdi Khola, Dobang, 2400 m a.s.1., 25.05.1995, leg. J. Martens \& W. Schawaller.

REMARKS. This species has been described from a single locality in central Nepal [Golovatch, 1994b]. The new sample can thus be regarded as near-topotypical. New illustrations are provided to document the identity (Fig. 5).

\section{Anoplodesmus magnus sp.n.}

Figs $6 \& 7$.

HOLOTYPE $\sigma^{7}$ (SMF), Nepal, Panchthar District, upper reaches of Mai Majuwa Khola, Dhorpar Kharka, 2700 m a.s.1., 27-28. 08.1983, leg. J. Martens \& B. Daams.

DIAGNOSIS. Using the available keys in Attems [1937] and Jeekel [1965], the new species differs from all large-sized Anoplodesmus species showing particularly well developed paraterga and simple gonopods [cf. Golovatch, 2000] by broadly to increasingly narrowly rounded caudal corners of paraterga 1-18, of which only those in segments 2-4 and 17-19 are produced behind the rear tergal margin, as well as in the relatively broad paratergal calluses, the absence of $\sigma^{7}$ leg modifications, the presence of a single subtriangular sternal lobe between $\sigma^{T}$ coxae 4 , coupled with a very prominent lateral lobe (l) adjacent to the solenophore (sph).

NAME. To emphasize its large size; adjective.

DESCRIPTION. Length ca $46 \mathrm{~mm}$, width of midbody pro- and metazonae 4.5 and $5.5 \mathrm{~mm}$, respectively. General coloration in alcohol brown with contrasting yellow antennae, paraterga, epiproct, legs and, partly, venter (Fig. 6).

In width, head $<$ collum $<$ segment $3=4<2<5$ 16 ; thereafter body gradually tapering. Clypeolabral region sparsely setose, vertigial region bare; epicranial suture distinct, starting between antennal sockets. Antennae slender, non-clavate, rather short, only slightly extending back behind segment 2 when stretched dorsally $\left(\sigma^{7}\right)$; antennomeres 2-6 subequal, much longer than $1^{\text {st }}$ and $7^{\text {th }}$. Dorsum very convex; paraterga lying at about upper $1 / 3$ of body, quite strongly developed (Figs $6 \mathrm{~A}, \mathrm{C}, 7 \mathrm{~A})$; a distinct, regularly declivous, ventrolateral, rather narrowly rounded, subtriangular lobe not produced behind rear tergal margin in collum (Fig. 6A); a similarly rather narrowly rounded and subtriangular, but slightly produced caudally behind rear tergal margin and less strongly declivous in segments 2-4, especially low and produced also forward in segment 2 (Fig. 6A). Lateral calluses on following paraterga smooth, broad, especially thick in pore-bearing segments, thinner in poreless ones, subhorizontal, very clearly delimited by a sulcus both dorsally and ventral- 

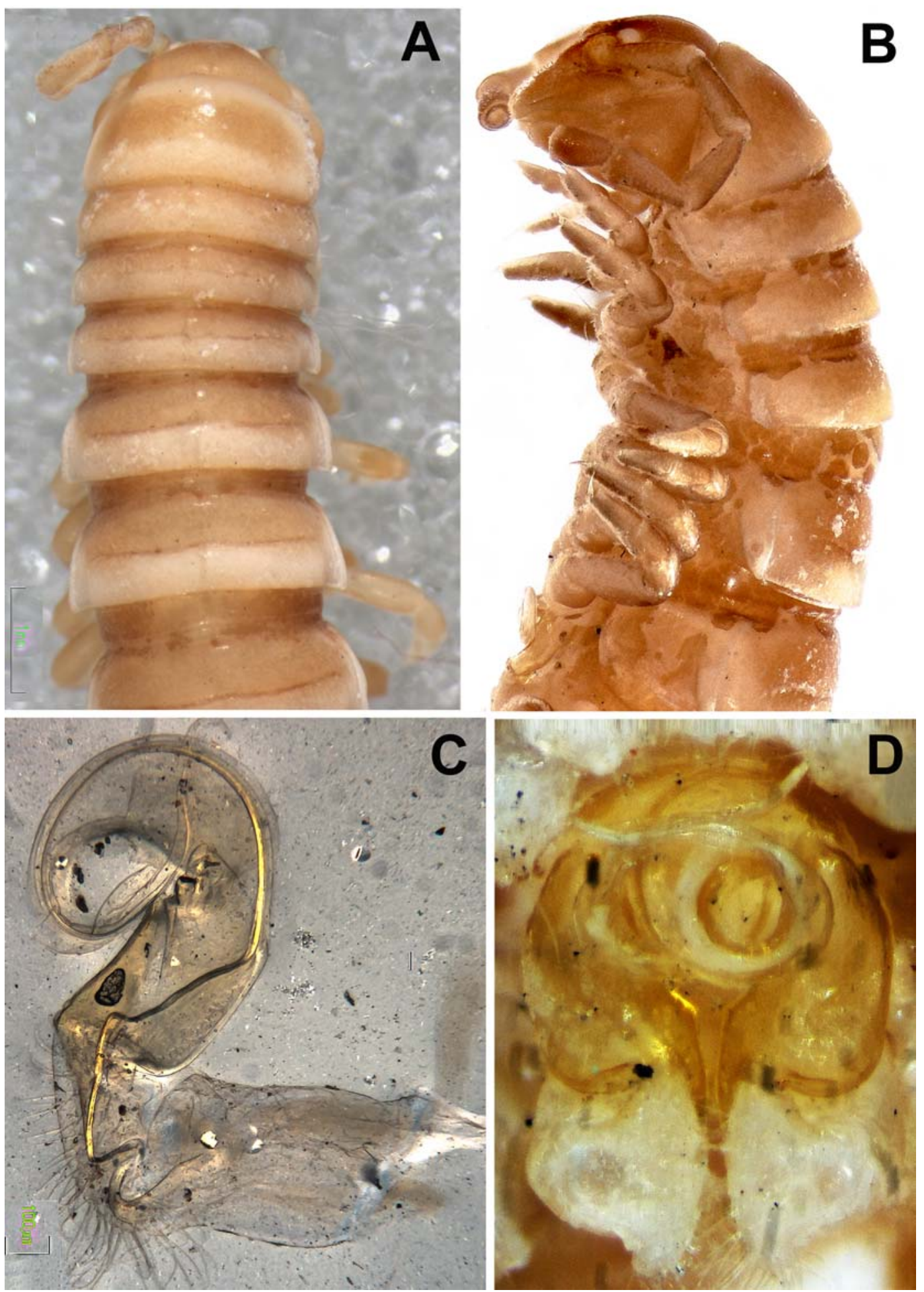

Fig. 1. Streptogonopus phipsoni (Pocock, 1892), $0^{7}$ from Ahmedabad, India (NHMW, det. C. Attems). A \& B — anterior part of body, dorsal and lateral views, respectively; C \& D - gonopods, mesal and ventral views, respectively. All pictures courtesy N. Akkari and E. Schiller. Pictures A, B and D taken not to scale.

Рис. 1. Streptogonopus phipsoni (Pocock, 1892), О7 из Ахмедабада (Индия) (NHMW, det. C. Attems). А и В - передняя часть тела, соответственно сверху и сбоку; С и D - гоноподы, соответственно изнутри и снизу. Все фотографии любезно предоставлены N. Akkari и E. Schiller. Фотографии A, В и D без масштаба. 

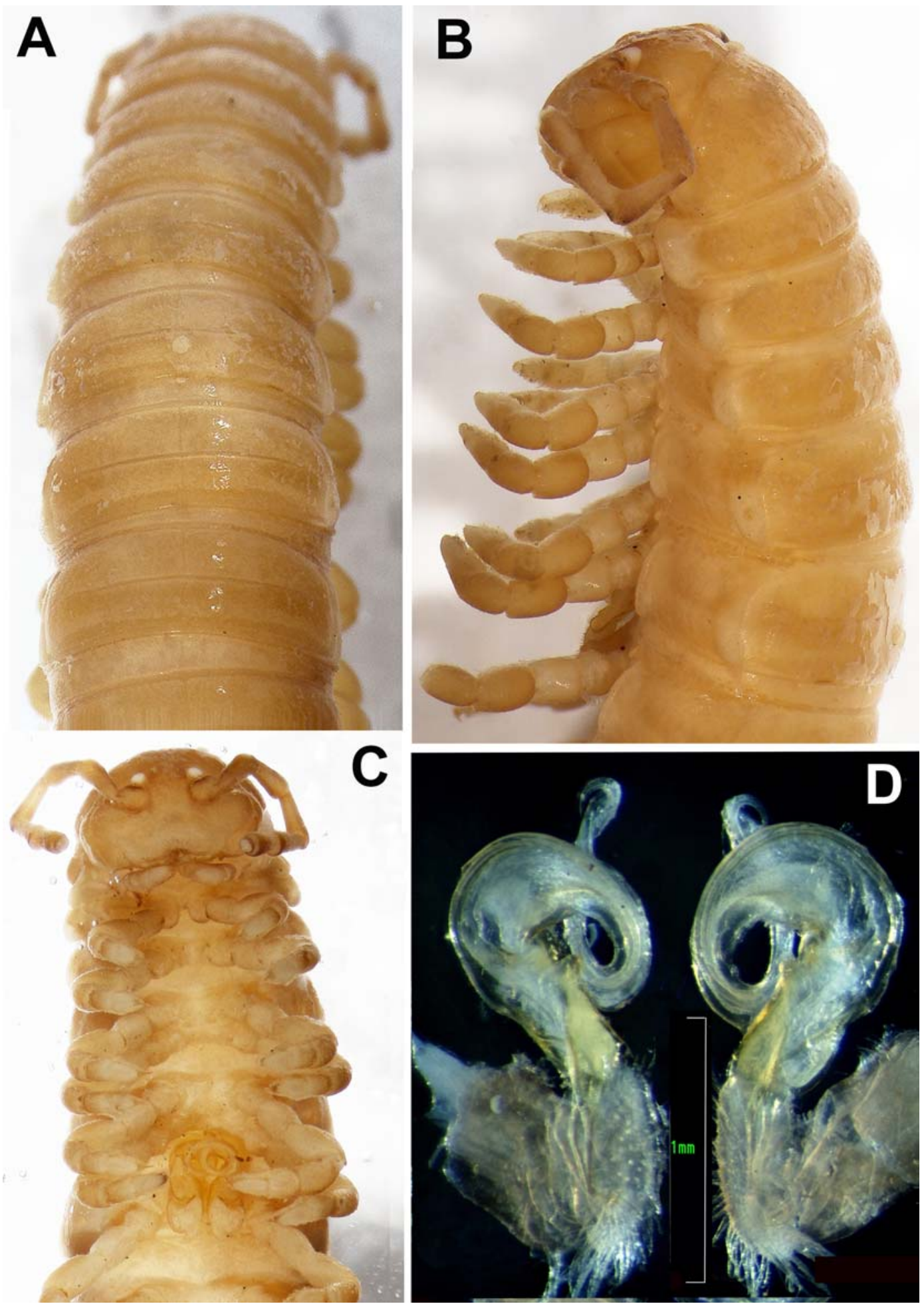

Fig. 2. Streptogonopus nitens Attems, 1936, O syntype from Ahmedabad, India (NHMW, det. C. Attems). A-C - anterior part of body, dorsal, lateral and ventral views, respectively; D - gonopods, ventral view. All pictures courtesy N. Akkari and E. Schiller. Pictures A-C taken not to scale.

Рис. 2. Streptogonopus nitens Attems, 1936, синтип О’ из Ахмедабада (Индия) (NHMW, det. C. Attems). A-C - передняя часть тела, соответственно сверху, сбоку и снизу; D - гоноподы, снизу. Все фотографии любезно предоставлены N. Akkari и E. Schiller. Фотографии А-C без масштаба. 


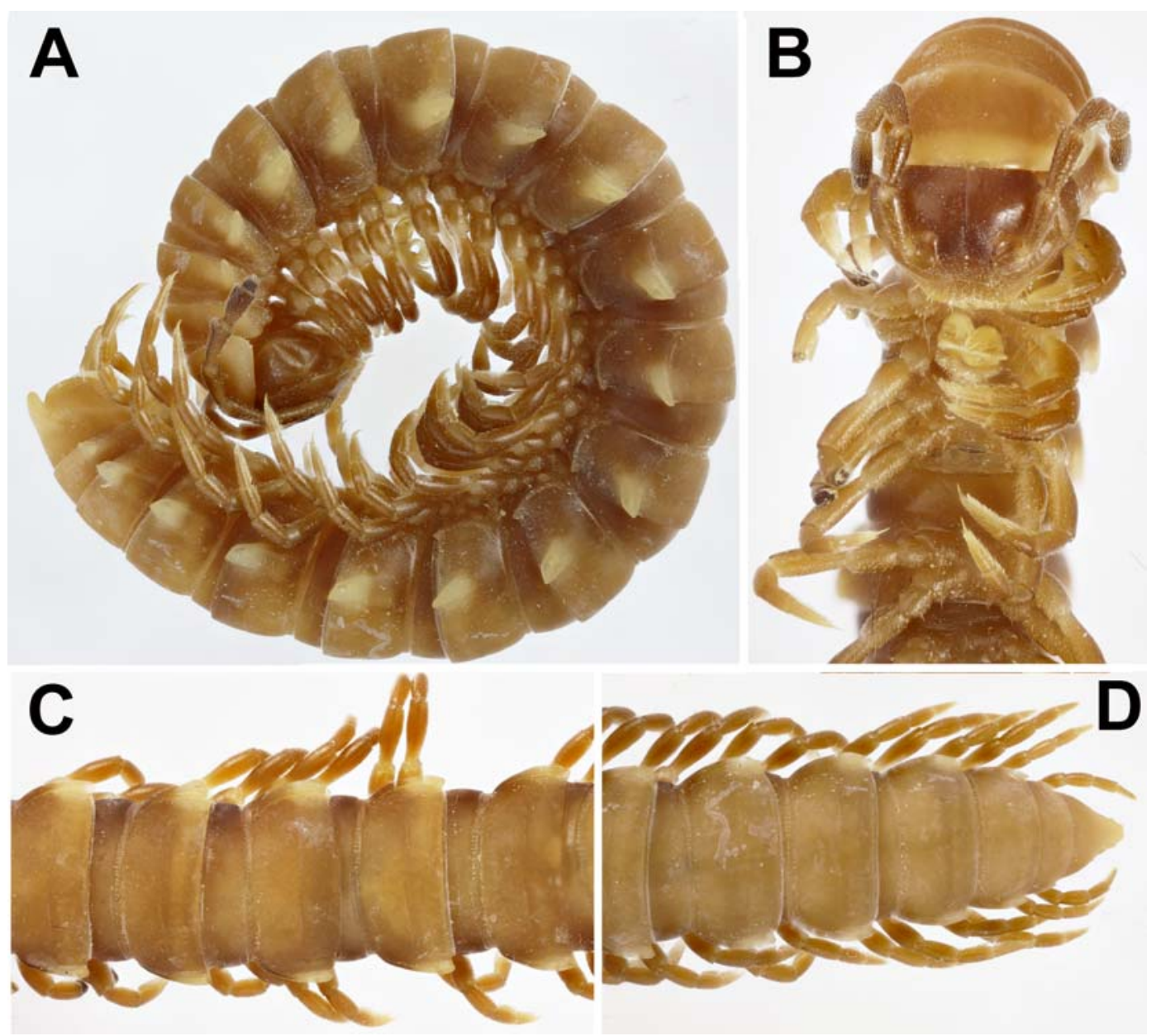

Fig. 3. Streptogonopus phipsoni (Pocock, 1892), O from Nepal. A - habitus, lateral view; B - anterior part of body, ventral view; C \& D - middle and caudal parts of body, respectively, dorsal view. Pictures by K. Makarov, taken not to scale.

Рис. 3. Streptogonopus phipsoni (Pocock, 1892), о7 из Непала. А — общий вид, сбоку; В — передняя часть тела, снизу; С и D соответственно средняя и задняя части тела, сбоку. Фотографии К. Макарова, без масштаба.

Fig. 4. Streptogonopus phipsoni (Pocock, 1892), $O^{7}$ from Nepal. A - segment 10, lateral view; B - epiproct, dorsal view; $\mathrm{C}$ - hypoproct, ventral view; D \& E - right gonopod, mesal and lateral views, respectively. Scale bars: $1.0(\mathrm{~A}-\mathrm{C})$ \& $0.5 \mathrm{~mm}(\mathrm{D}, \mathrm{E})$.

Рис. 4. Streptogonopus phipsoni (Pocock, 1892), О7 из Непала. А - сегмент 10, сбоку; В эпипрокт, сверху; C - гипопрокт, снизу; D и $\mathrm{E}$ - правый гонопод, соответственно изнутри и сбоку. Масштаб: $1,0(\mathrm{~A}-\mathrm{C})$ и 0,5 мм $(\mathrm{D}, \mathrm{E})$.
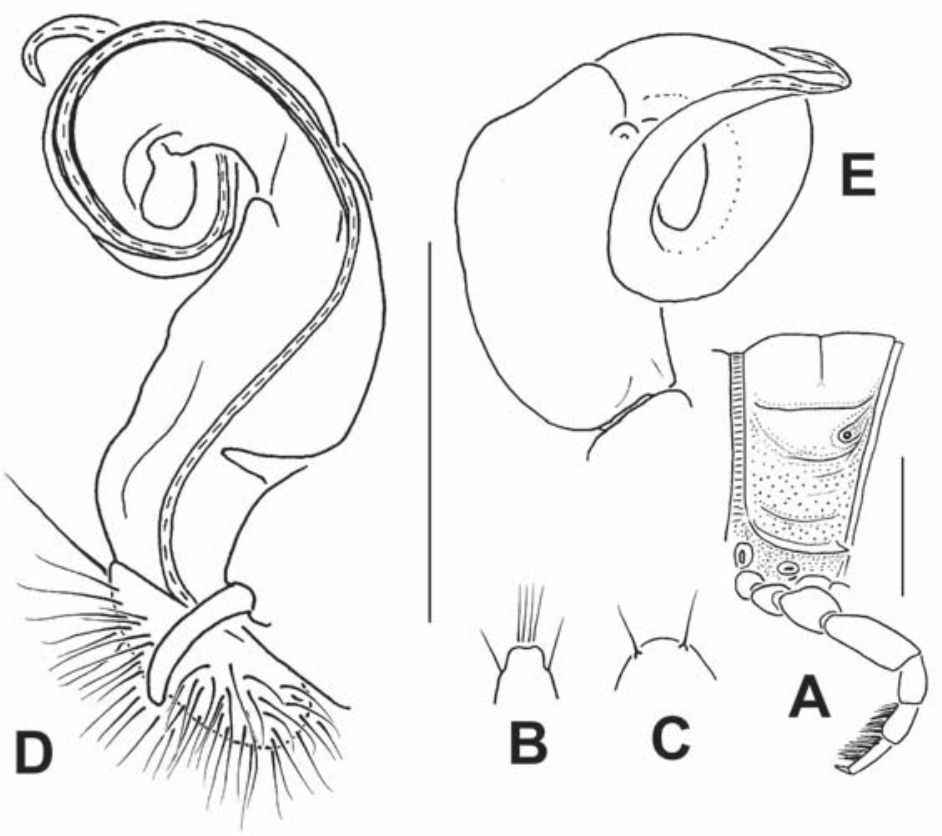

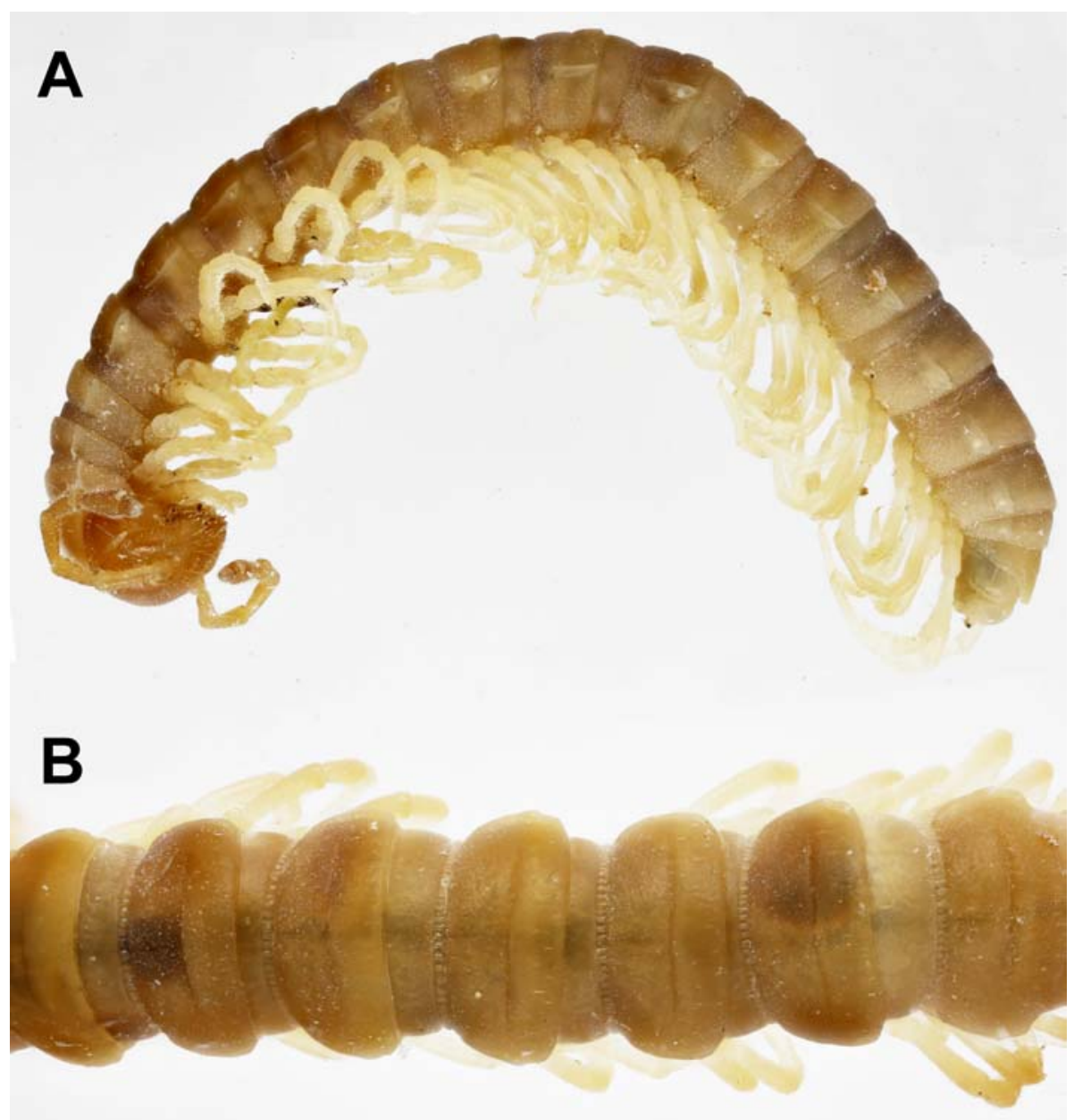

Fig. 5. Delarthrum hirsutum (Golovatch, 1994), Oొ from Dobang. A — habitus, lateral view; B - middle part of body, dorsal view. Pictures by K. Makarov, taken not to scale.

Рис. 5. Delarthrum hirsutum (Golovatch, 1994), О’ из Dobang. А — общий вид, сбоку; В - средняя часть тела, сверху. Фотографии К. Макарова, без масштаба.

ly, increasingly narrowly rounded caudally, barely produced behind rear tergal margin in segments $2-4$ and 17 , subspiniform, distinctly projecting behind rear tergal margin, but still narrowly rounded in segment 18, sharp and spiniform in $19^{\text {th }}$ (Figs 6A-E, 7C). In dorsal view, pore-bearing calluses faintly sinuate in front of ozopore; ozopores lateral, each lying inside a shallow round pit ca $1 / 4$ of callus length off caudal corner (Figs $6 \mathrm{D}, \mathrm{E}, 7 \mathrm{~B})$. Body surface generally shining and smooth throughout, below paraterga finely microgranulate (Fig. 7A). Axial line wanting. Transverse metatergal sulcus distinct, but thin, nearly reaching bases of paraterga and finely beaded in segments $5-18$, absent from $19^{\text {th }}$ (Fig. 6D, E). Tergal setae fully abraded, pattern untraceable. Stricture dividing pro- and metazonae narrow and rather shallow, moderately beaded at bottom (Figs 6D, 7A, B). Pleurosternal carinae very distinct, rounded, arcuate ridges devoid of any teeth and gradually disappearing towards segment 13 (Figs 6A, C, 7A). Epiproct (Figs 6C, E, 7D) long, digitiform, subtruncate at apex, subapical lateral papillae indistinct, well removed from tip. Hypoproct (Fig. 7E) nearly semi-circular, caudal 1+1 setae clearly separated, borne on vestigial knobs.

Sternites without modifications, densely setose; cross-impressions modest, but evident; a single, subtriangular, apically rounded, caudad directed, setose lobe between coxae 4 (Fig. 7F). Legs long and slender, ca 1.4-1.5 times as long as midbody height $\left(\mathrm{O}^{7}\right)$ (Figs 6A, C, 7G), prefemora not swollen laterally; adenostyles absent; tarsal brushes present only in legs $1-7$, thereafter gradually thinning out $\left(\sigma^{7}\right)$.

Gonopod aperture transversely 8-shaped. Gonopods (Figs 6F, 7H, I) fairly simple, short and stout; coxite short, subcylindrical, setose distoventrally; prefemoral part as usual, densely setose, also short, about $1 / 3$ the length of acropodite and only slightly shorter than femorite; the latter simple, curved mesad, with a distinct distofemoral process (p); postfemoral region (pfe) about as short as, and demarcated by a distinct, distolateral sulcus from, femorite; solenophore (sph) branch slender, nearly as long as a short, but flagelliform solenomere (sl) it supports; a large lateral lobe (I) at base of sph. 


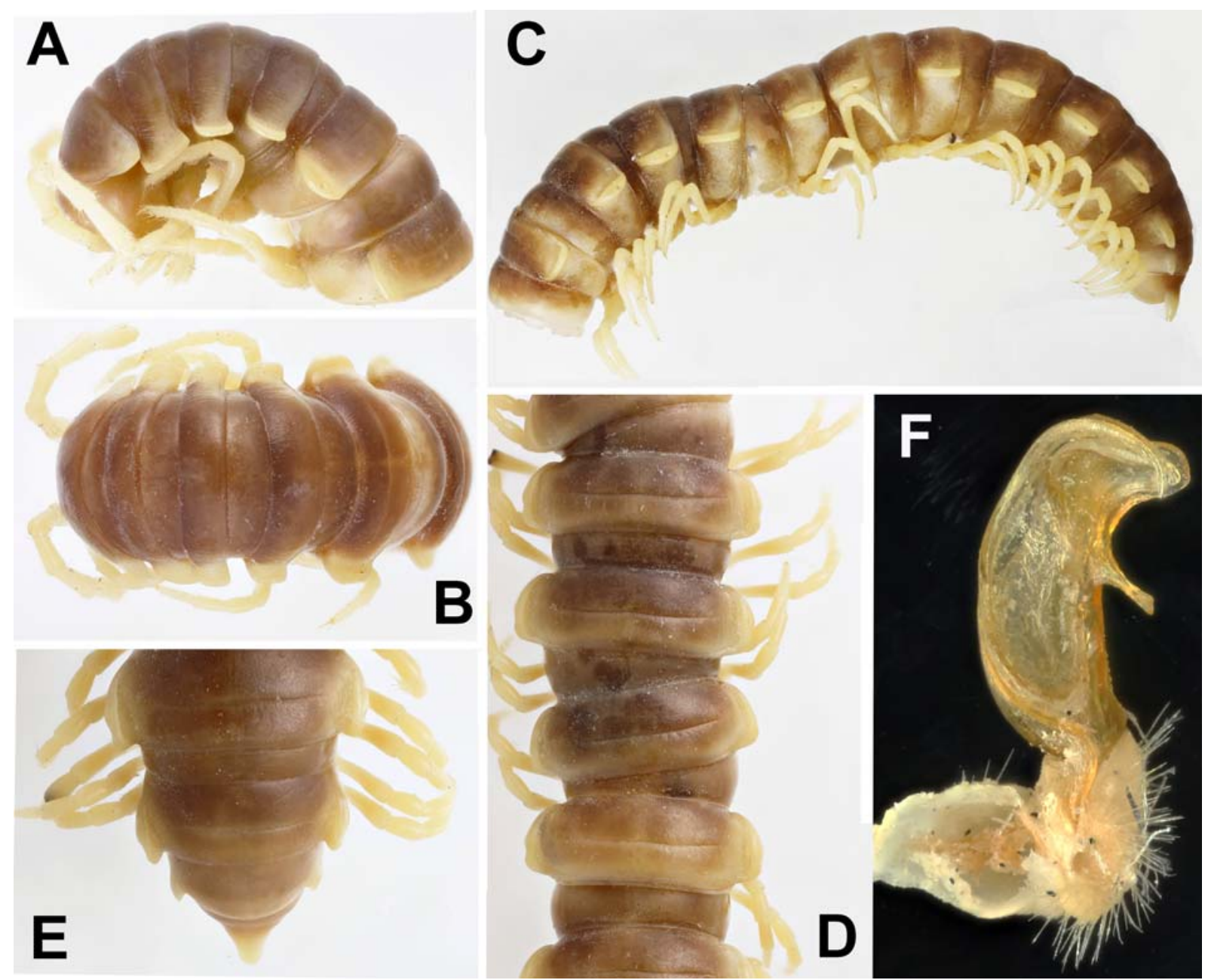

Fig. 6. Anoplodesmus magnus sp.n., $0^{7}$ holotype. A \& B - anterior part of body, lateral and dorsal views, respectively; C - body segments 8-20, lateral view; D \& E - middle and caudal parts of body, respectively, dorsal view; F - left gonopod, mesal view. Pictures by K. Makarov, taken not to scale.

Pис. 6. Anoplodesmus magnus sp.n., голотип О'. А и В - передняя часть тела, соответственно сбоку и сверху; С - сегменты тела 8-20, сбоку; D и Е - соответственно средняя и задняя части тела, сверху; F - левый гонопод, изнутри. Фотографии К. Макарова, без масштаба.

\section{Kronopolites coriaceus sp.n.}

Figs $8 \& 9$.

HOLOTYPE $\sigma^{T}$ (SMF), Nepal, Kaski Distr., above Pothana, 2000 m a.s.1., 27-29.04.1995, leg. J. Martens \& W. Schawaller.

PARATYPE: $10^{7}$ (SMF), same data, together with holotype.

DIAGNOSIS. Using the latest key to Kronopolites Attems, 1914, by Likhitrakarn et al. [2015a], this new species differs from both other congeners showing clearly rugose to roughly rugose-granulate metaterga, $K$. rugosus Golovatch, 2013, from Yunnan Prov., China [Golovatch, 2013a], and K. semirugosus Golovatch, 2013, from Sichuan Prov, China [Golovatch, 2013b], primarily by a much lighter coloration and the shape of both postfemoral processes of the gonopod forming a compact fork.

NAME. To emphasize the coriaceous metaterga; adjective.

DESCRIPTION. Length ca $35 \mathrm{~mm}$, width of midbody pro- and metazonae 2.4 and $3.9 \mathrm{~mm}$ (holotype) or
2.2 and $3.6 \mathrm{~mm}$ (paratype), respectively. General coloration in alcohol light brown with yellow antennae, paraterga, epiproct, legs and venter (Fig. 8).

In width, head $<$ segment $2=3<$ collum $=4<2<$ 5-16; thereafter body gradually tapering. Clypeolabral region densely, vertigial region sparsely, setose; epicranial suture a very thin line. Antennae poorly clavate, slender and long, slightly extending back behind segment 3 when stretched dorsally $\left(\sigma^{7}\right)$; antennomeres 2-5 subequal, a little longer than $6^{\text {th }}$, much longer than subequal $1^{\text {st }}$ and $7^{\text {th }}$. Dorsum mostly only slightly convex; paraterga on collum moderately declined, represented by very strong, sharp, triangular teeth considerably produced behind rear tergal margin (Fig. 8C); postcollum paraterga set high, at about upper 1/4 of body, quite strongly developed, clearly upturned, lying above dorsum, likewise sharp teeth, projecting behind rear margin also in segments 2-4 and 16-19 (Figs 8, 9A, B). Lateral calluses on paraterga rather narrow, 


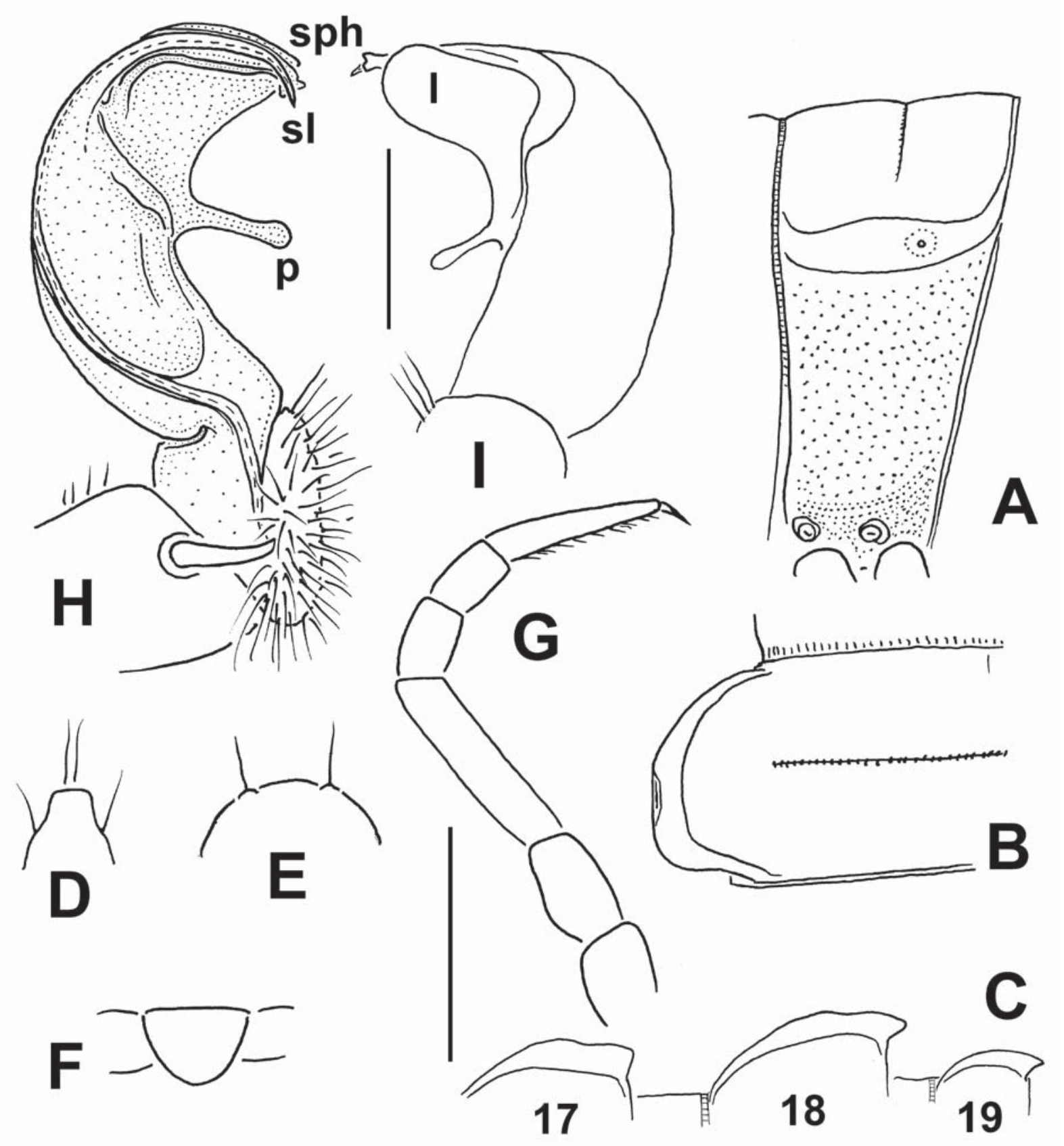

Fig. 7. Anoplodesmus magnus sp.n., $\mathrm{O}^{\mathrm{T}}$ holotype. A \& B — left half of segment 10, lateral and dorsal views, respectively; C — right halves of body segments 17-19, dorsal view; D - epiproct, dorsal view; E - hypoproct, ventral view; F - sternal lobe between coxae 4, ventral view; G - leg 7; H \& I - left gonopod, mesal and lateral views, respectively. Scale bars: 2.0 (A-G) \& $0.5 \mathrm{~mm}(\mathrm{H}, \mathrm{I})$

Рис. 7. Anoplodesmus magnus sp.n., голотип О7. А и В - левая половина сегмента 10 , соответственно сбоку и сверху; С правые половины сегментов тела 17-19, сверху; D - эпипрокт, сверху; Е - гипопрокт, снизу; F — стернальная пластина между тазиками 4 , снизу; $\mathrm{G}$ - нога $7 ; \mathrm{H} \& \mathrm{I}$ - левый гонопод, соответственно изнутри и сбоку. Масштаб: $2,0(\mathrm{~A}-\mathrm{C})$ и 0,5 мм $(\mathrm{D}, \mathrm{E})$.

abundantly microdenticulate and microsetose at lateral margin, thicker in pore-bearing segments, thinner in poreless ones, very clearly delimited by a sulcus dorsally and, in pore-bearing segments only, ventrally. In dorsal view, pore-bearing calluses faintly sinuate in front of ozopore; ozopores dorsolateral, each lying inside a shallow ovoid groove ca $1 / 3-1 / 4$ of callus length off caudal corner (Figs 8, 9A, B). Body surface generally shining, metaterga roughly coriaceous, granulated, below paraterga finely microgranulate (Fig. 9A, B). Axial line evident on all postcollum metaterga. Transverse metatergal sulcus distinct, reaching bases of paraterga in segments 2-19 (Figs 8C-E, 9A). Tergal setae very short, inconspicuous, largely abraded, pat- 


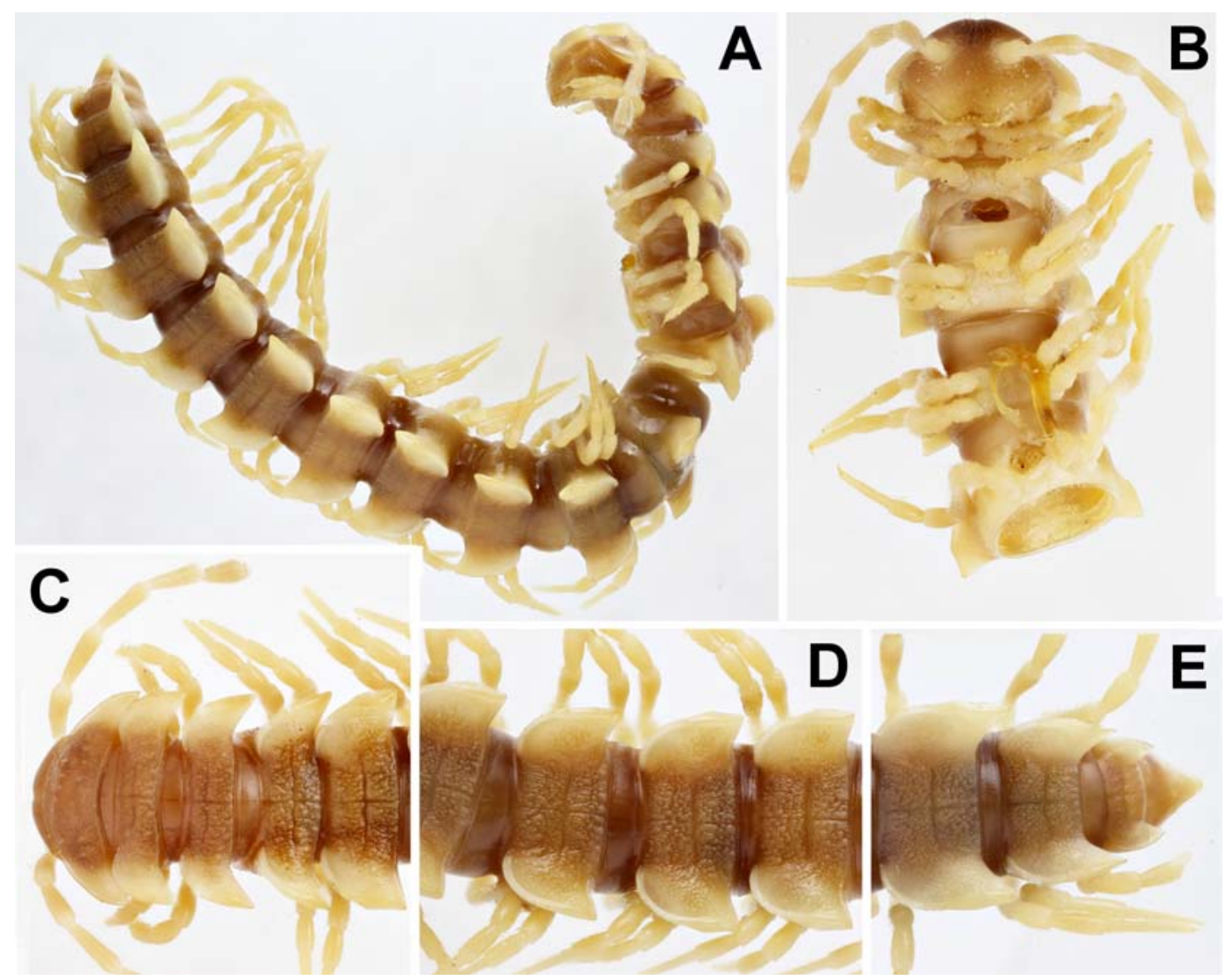

Fig. 8. Kronopolites coriaceus sp.n., $\mathrm{O}^{\mathrm{T}}$ holotype. A - habitus, lateral view; B \& C - anterior part of body, ventral and dorsal views, respectively; D \& E - middle and caudal parts of body, respectively, dorsal view. Pictures by K. Makarov, taken not to scale.

Рис. 8. Kronopolites coriaceus sp.n., голотип О'. А - общий вид, сбоку; В и С - передняя часть тела, соответственно снизу и сверху; D и Е - соответственно средняя и задняя части тела, сверху. Фотографии К. Макарова, без масштаба.

tern untraceable. Stricture dividing pro- and metazonae rather broad and shallow, very finely striolate dorsally at bottom (Fig. 9A). Pleurosternal carinae evident, anteriorly and posteriorly rounded ridges devoid of any teeth and gradually disappearing towards segment 9 . Epiproct (Figs 8E, 9C) rather long, digitiform, concave at apex, subapical lateral papillae very small and removed from tip. Hypoproct (Fig. 9D) nearly semi-circular, caudal $1+1$ setae clearly separated, borne on vestigial knobs and somewhat removed from caudal margin.

Sternites without modifications, densely setose; cross-impressions very weak; a single, subquadrate, setose lobe between coxae 4 (Figs 8B, 9E). Legs densely setose ventrally, very long and slender, ca 2.0-2.1 times as long as midbody height $\left(\mathrm{O}^{7}\right)$ (Figs $\left.8,9 \mathrm{~B}\right)$, prefemora not swollen laterally, but femora 7 clearly incrassate (Fig. 8B); adenostyles absent; tarsal brushes present only in legs $1-3$, thereafter gradually thinning out $\left(\sigma^{7}\right)$.

Gonopod aperture transversely 8 -shaped. Gonopods (Figs 9F, G) rather complex, elongate and falcate; coxite medium-sized, subcylindrical, setose distoventrally; prefemoral part as usual, densely setose, short, about $1 / 2$ the length of femorite; the latter simple, untwisted, suberect, faintly enlarged distad, showing an evident, mesal, longitudinal groove delimited by a thicker fold on each side, set off from acropodite by a distinct lateral sulcus; seminal groove running entirely on mesal face of femorite; another clear lateral sulcus lying more distally, demarcating a short postfemoral part, the latter carrying a typical, but compact fork of two subequal lateral processes (a and b); acropodite a long, recurved, slender, lamellar solenophore (sph) showing a complex and narrowly rounded tip, supporting a nearly as long, flagelliform solenomere (sl) branching off at distal end of femorite.

REMARK. This is the first formal record of Kronopolites in Nepal.

\section{Beronodesmus minutus sp.n.}

Figs $10 \& 11$

HOLOTYPE $0^{\top}$ (SMF), Nepal, Taplejung Distr., Lassetham Kharka, NW of Yamputhin, 3300-3500 m a.s.l., mature AbiesRhododendron forest, 6-9.05.1988, leg. J. Martens \& W. Schawaller.

DIAGNOSIS. Differs from B. pallidus Golovatch, 2014, the sole, and type, species of Beronodesmus Golovatch, 2014, by the much smaller size (ca 7 vs $16-$ $17 \mathrm{~mm}$ in $\left.\mathrm{O}^{7}\right)$, the relatively short legs (0.9-1.0 vs $1.2-1.3$ times as long as body height), the larger distofemoral processes $\mathbf{a}$ and $\mathbf{b}$ of the gonopod, and some other 


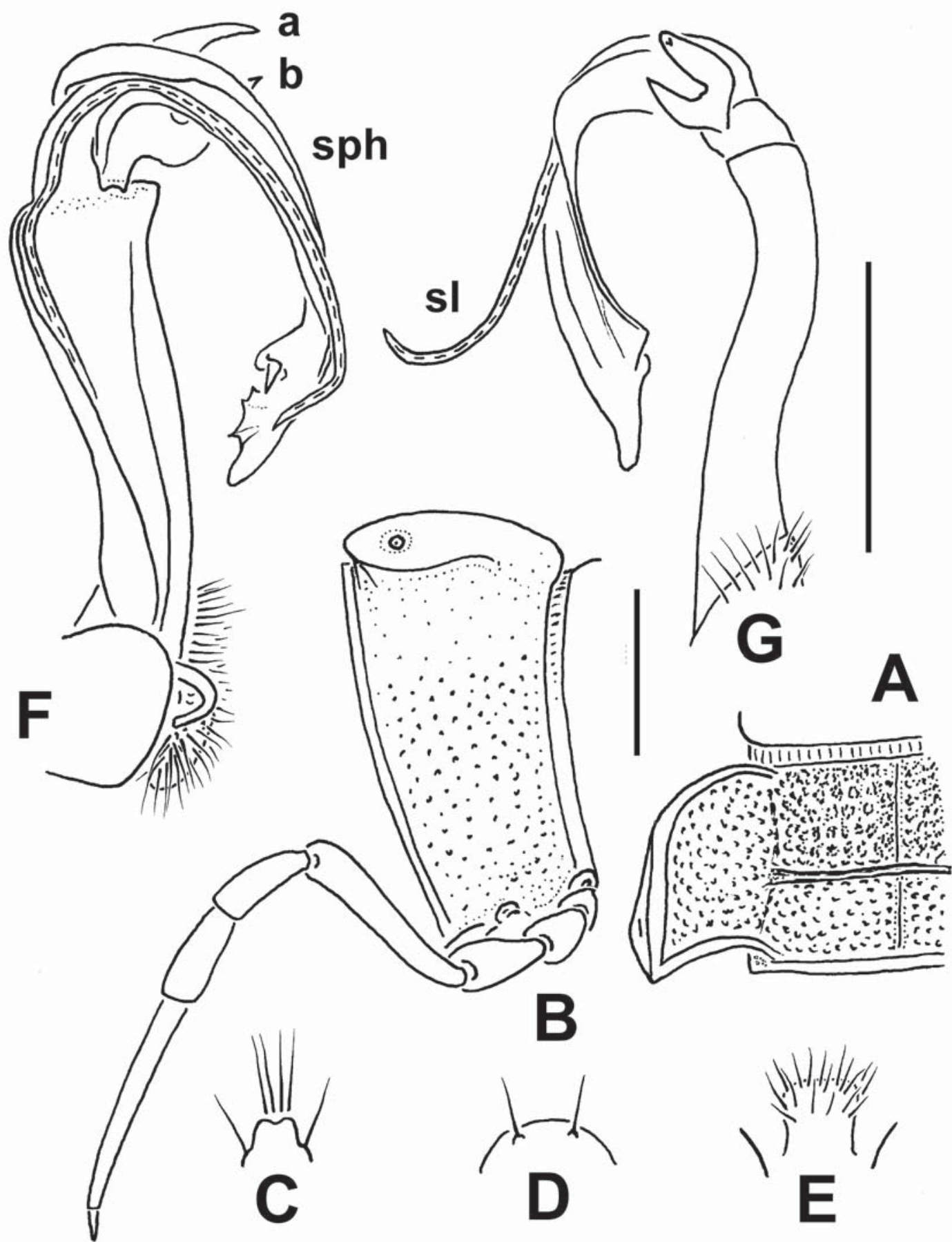

Fig. 9. Kronopolites coriaceus sp.n., $0^{7}$ holotype. A \& B - half of segment 10, dorsal and lateral views, respectively; C - epiproct, dorsal view; D - hypoproct, ventral view; E - sternal lobe between coxae 4, ventral view; F \& G - left gonopod, mesal and lateral views, respectively. Scale bars: $1.0 \mathrm{~mm}$.

Pис. 9. Kronopolites coriaceus sp.n., голотип О7. А и В — половина сегмента 10, соответственно сбоку и сверху; С - эпипрокт, сверху; D - гипопрокт, снизу; Е - стернальная пластина между тазиками 4, снизу; Е и G — левый гонопод, соответственно изнутри и сбоку. Масштаб: 1,0 мм.

structural details [Golovatch, 2014]. Most of these characters make B. minutus sp.n. distinguished from all other new congeners decribed hereafter (see also Key below).

NAME. To emphasize the particularly small size; adjective.
DESCRIPTION. Length ca $7 \mathrm{~mm}$, width of midbody pro- and metazonae 0.7 and $0.8 \mathrm{~mm}$, respectively; head broadest, $0.9 \mathrm{~mm}$ wide. General coloration in alcohol pallid (Fig. 10).

Body subcylindrical. In width, collum $<$ segment $2=$ $3<4<$ head $=5-16$; thereafter body gradually taper- 


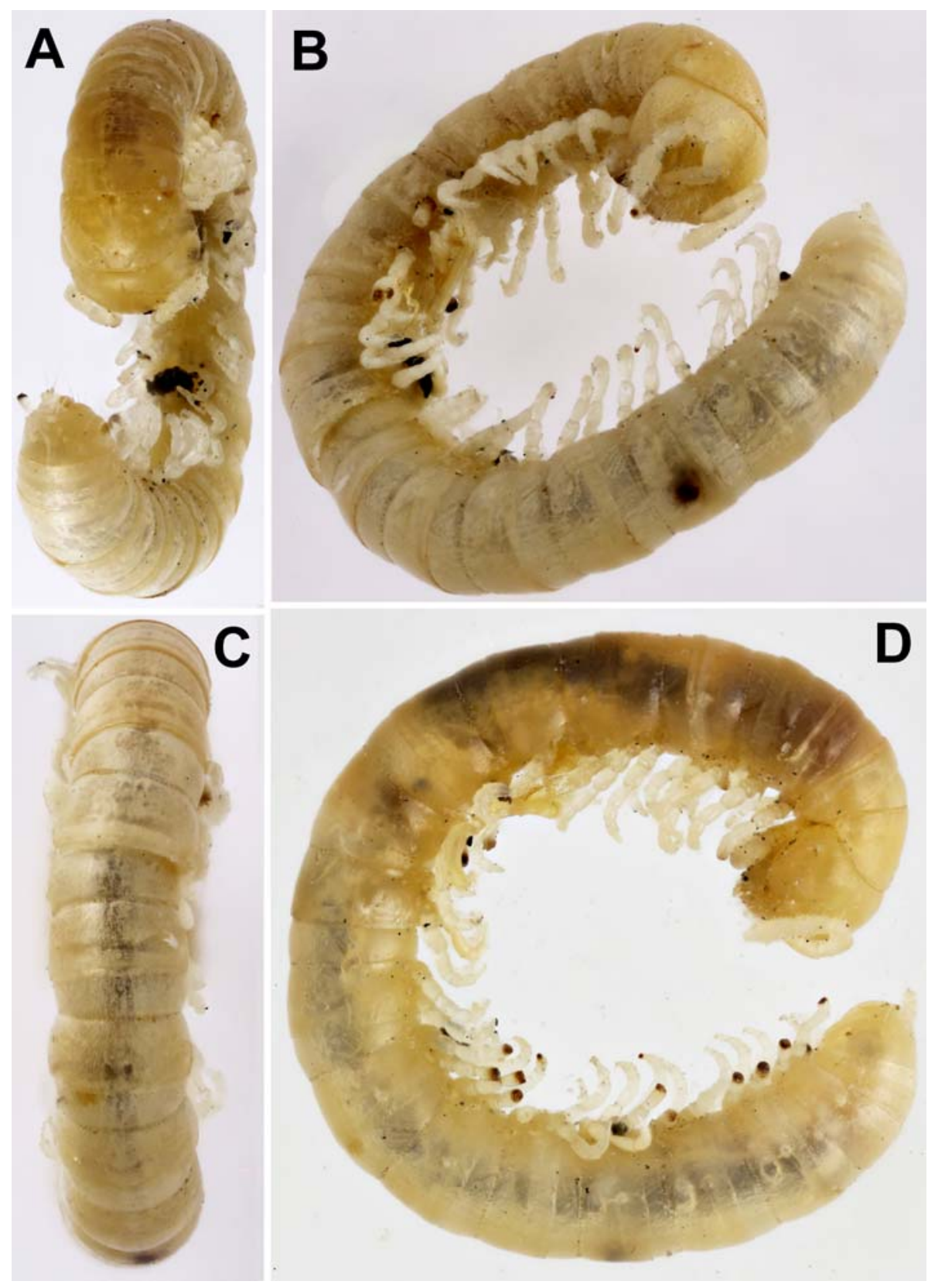

Fig. 10. Beronodesmus minutus sp.n., $\bigcirc^{7}$ holotype. A-D - habitus in various aspects. Pictures by K. Makarov, taken not to scale.

Рис. 10. Beronodesmus minutus sp.n., голотип О`. А-D - общий вид с разных сторон. Фотографии К. Макарова, без масштаба.

ing. Clypeolabral region sparsely setose, vertigial region bare; epicranial suture a thin line. Antennae rather clearly clavate, short, only slightly extending back behind collum when stretched dorsally $\left(\sigma^{7}\right)$; antennomeres 2-6 subequal in length, each much longer than subequal $1^{\text {st }}$ and $7^{\text {th }}$. Dorsum strongly convex, postcollum paraterga vestigial, each represented by a faint dorsal sulcus at about body midheight (Figs 10D, 11A). Ozopores lying inside a shallow ovoid pit ca $1 / 4$ of callus length off caudal corner (Fig. 11A). Body surface generally smooth and shining, only metazonae below paraterga very finely rugulose (Fig. 9A, B). Neither an axial line nor transverse metatergal sulci. Tergal setae abraded, pattern untraceable. Stricture dividing pro- and metazonae rather narrow and shallow, finely striolate at bottom dorsally and dorsolaterally (Fig. 11A). Pleurosternal carinae toothless caudally, visible only in segment 2. Epiproct (Figs 10A, 11B) rather long, digitiform, barely concave at apex, subapical lateral papillae small and well removed from tip. Hypoproct (Fig. 11C) semi-circular, caudal $1+1$ setae clearly separated, not borne on knobs, placed at caudal margin.

Sternites without modifications, sparsely setose, nearly flat; cross-impressions very weak; a single, roundly subtrapeziform, setose lobe between coxae 4 (Fig. 


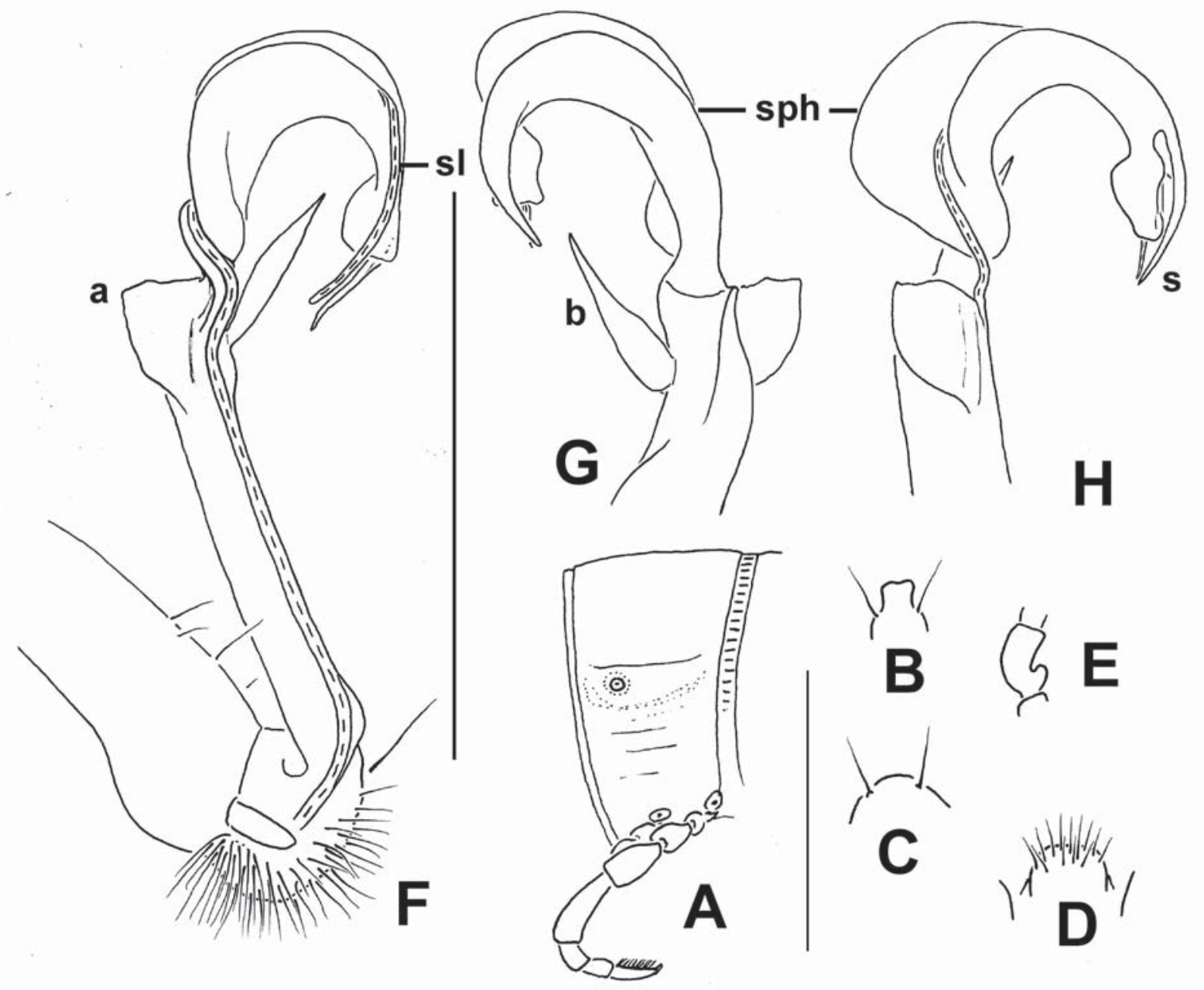

Fig. 11. Beronodesmus minutus sp.n., $\mathrm{O}^{7}$ holotype. A — segment 10, lateral view; B — epiproct, dorsal view; C — hypoproct, ventral view; D - sternal lobe between coxae 4, ventral view; E - femur 1, lateral view; F-H - left gonopod, mesal, lateral and subdorsal views, respectively. Scale bars: $0.5 \mathrm{~mm}$.

Рис. 11. Beronodesmus minutus sp.n., голотип О7. А - сегмент 10, сбоку; В - эпипрокт, сверху; С - гипопрокт, снизу; D стернальная пластина между тазиками 4, сзади; Е - бедро 1, сбоку; F-H - левый гонопод, соответственно изнутри, сбоку и примерно сверху. Масштаб: 0,5 мм.

11D). Legs densely setose ventrally, short and stout, ca $0.9-1.0$ times as long as midbody height $\left(\mathrm{O}^{7}\right)$ (Figs 10, 11A), prefemora not swollen laterally, but each femur 1 with a very strong, setose adenostyle (Fig. 11E); tarsal brushes present (Fig. 11A), gradually thinning out towards legs of segment $12\left(\mathrm{O}^{7}\right)$.

Gonopods (Figs $11 \mathrm{~F}-\mathrm{H}$ ) rather complex, elongate and falcate; coxite long, subcylindrical, sparsely setose distoventrally; prefemoral part as usual, densely setose, short, about $1 / 2$ the length of femorite; the latter simple, untwisted, suberect, faintly enlarged distad, distally bearing a subtriangular, phylloid, dorsal lobe (a) and a slender, lanceolate, apically acuminate, ventral process (b) before a cingulum setting off a slender, subcircular, lamellar acropodite (= solenophore, $\mathbf{s p h}$ ), the latter nearly as long as femorite, bifid distally, one of the apical branches being a long spine (s); seminal groove running entirely on mesal face of femorite, moving onto a long flagelliform solenomere (sl) at base of $\mathbf{b}$; both sph and sl subequal in length.

REMARKS. Initially, the genus Beronodesmus Golovatch, 2014 has been assigned to the tribe Chamberliniini Wang, 1956 on account of the poorly developed paraterga, the presence of a sternal lobe between $\checkmark$ coxae 4 and of an adenostyle on $\sigma^{7}$ femur 1 , as well as an untwisted, long and suberect gonopod femorite carrying the seminal groove only on its mesal face and supplied with two projections distally; the distalmost of these latter lies at the base of a geniculation, being delimited by a cingulum which marks the onset of a long flagelliform solenomere supported by a similarly long, mesally directed, ribbon-shaped acropodite (= solenophore). The latter is devoid of a postfemoral sulcus/region [Golovatch, 2014].

This tribe presently contains six further genera from East and/or Southeast Asia [Nguyen, Siewald, 2013], 

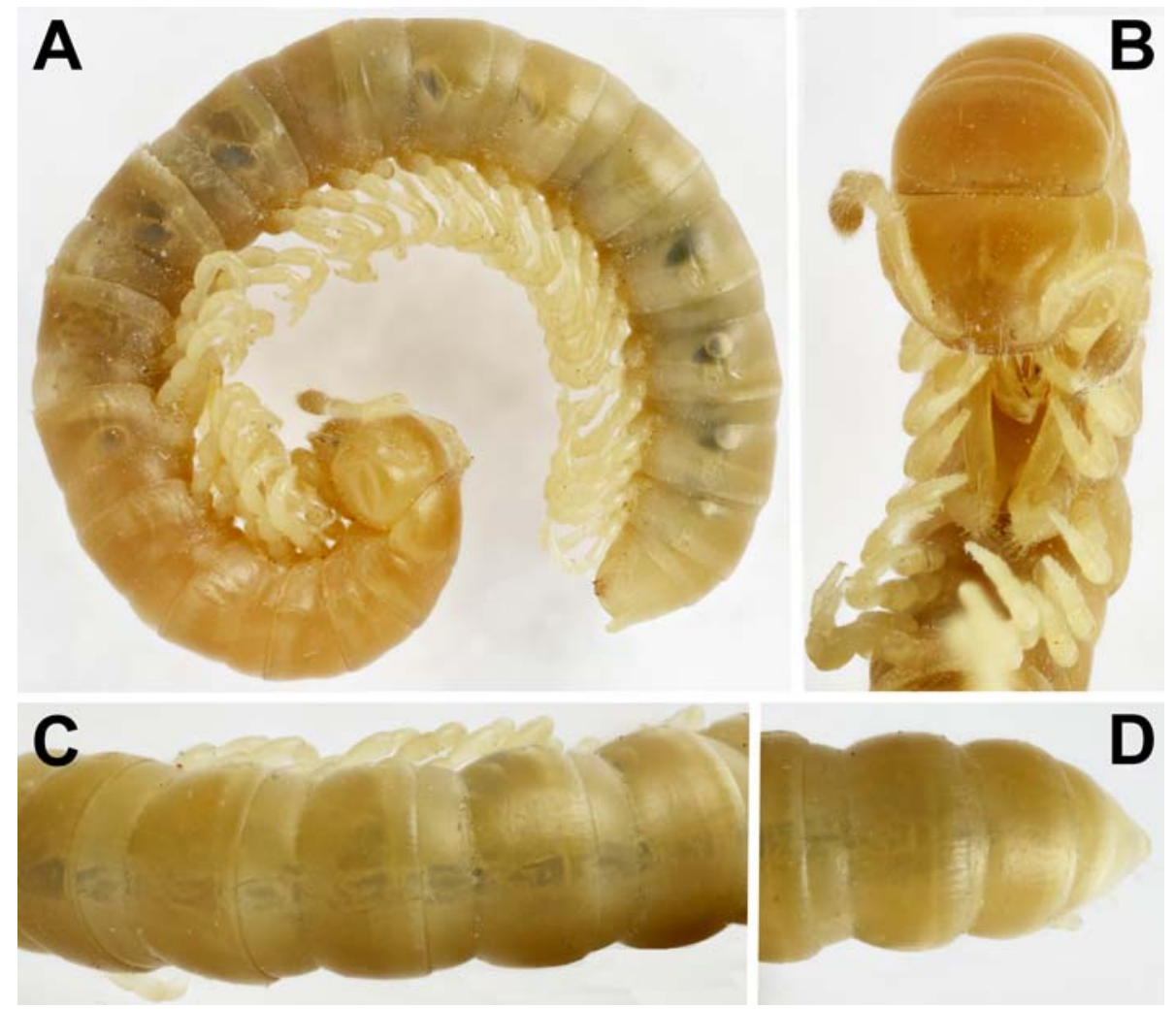

Fig. 12. Beronodesmus gorkhalis sp.n., $\sigma^{\top}$ holotype. A habitus, lateral view; B-D - anterior, middle and posterior parts of body, ventral, dorsal and dorsal views, respectively. Pictures by $\mathrm{K}$. Makarov, taken not to scale.

Рис. 12. Beronodesmus gorkhalis sp.n., голотип O'. А общий вид, сбоку; В-D - передняя, средняя и задняя части тела, соответственно снизу, сверху и сверху. Фотографии К. Макарова, без масштаба. all keyed or briefly redefined [Nguyen, Korós, 2011; Golovatch, 2014]. One more, new genus is added below.

Until recently, the tribe Tonkinosomatini Jeekel, 1968 was considered to comprise two genera: Tonkinosoma Jeekel, 1953 and Sellanucheza Enghoff, Nguyen et Golovatch, 2004, both keyed [Nguyen, 2011]. Golovatch [2013a, b] transferred Sellanucheza to, and informally synonymized the Tonkinosomatini with, the Sulciferini. However, in view of the fresh discovery of Beronodesmus, the above arrangement requires revision.

The Tonkinosomatini is indeed a superfluous taxon [Golovatch, 2013a], but eventually it is a new junior subjective synonym of Chamberliniini, not Sulciferini, syn.n. Merging these two former tribes together is warranted by the striking similarities they share in gonopod structure, i.e. a long and mostly slender femorite, either twisted or not, with or without outgrowths distally, which is set off from the acropodite by a geniculation cingulum. Basal to it, a postfemoral part is sometimes distinguished due to an oblique distolateral sulcus on the femorite. The solenophore is strongly recurved mesad, likewise long, circular or nearly so, ribbon-shaped and lamellar, mostly sheathing and/or supporting a long solenomere, either flagelliform or rather thick.

These conditions are basically observed in Tonkinosoma and Sellanucheza as well, albeit the geniculation of the gonopods is still incomplete, not so strongly marked as in most other genera of Chamberliniini. The close affinities of both these genera have long been noted [Hoffman, 1961; Golovatch, 2013a]. Considering the several species of Beronodesmus now known (see also below), the gonopod geniculation in this genus is sometimes not so complete either, strongly reminding of the rather regularly falcate gonopods observed in Sellanucheza or Tonkinosoma. However, these three genera can easily be distinguished as follows.

Beronodesmus: small- to medium-sized (up to about $2 \mathrm{~cm}$ long); paraterga very small; adenostyles in $\sigma^{7}$ femora 1 present (almost unique in the tribe, shared only with Beronodesmoides gen.n.); gonopod femorite long, suberect, untwisted (= most of seminal groove running on mesal face), with a couple of distal outgrowths, but without a postfemoral portion; solenomere flagelliform, about as long as a circular or subcircular solenophore.

Eight species, all from eastern Nepal.

Sellanucheza: large-sized ( $>4 \mathrm{~cm}$ long); paraterga very small; gonopod femorite long, curved, twisted about midway, with one distofemoral outgrowth and a parabasal process on solenophore, but without a postfemoral portion; solenomere flagelliform, about as long as a circular or subcircular solenophore.

Six species ranging from southern China to northern and central Vietnam, all keyed [Golovatch, 2013b].

Tonkinosoma: large-sized ( $>4 \mathrm{~cm}$ long); paraterga small; gonopod femorite long, curved, untwisted, with neither distal outgrowths nor a postfemoral portion; solenomere flagelliform, nearly as long as a circular or subcircular solenophore. 


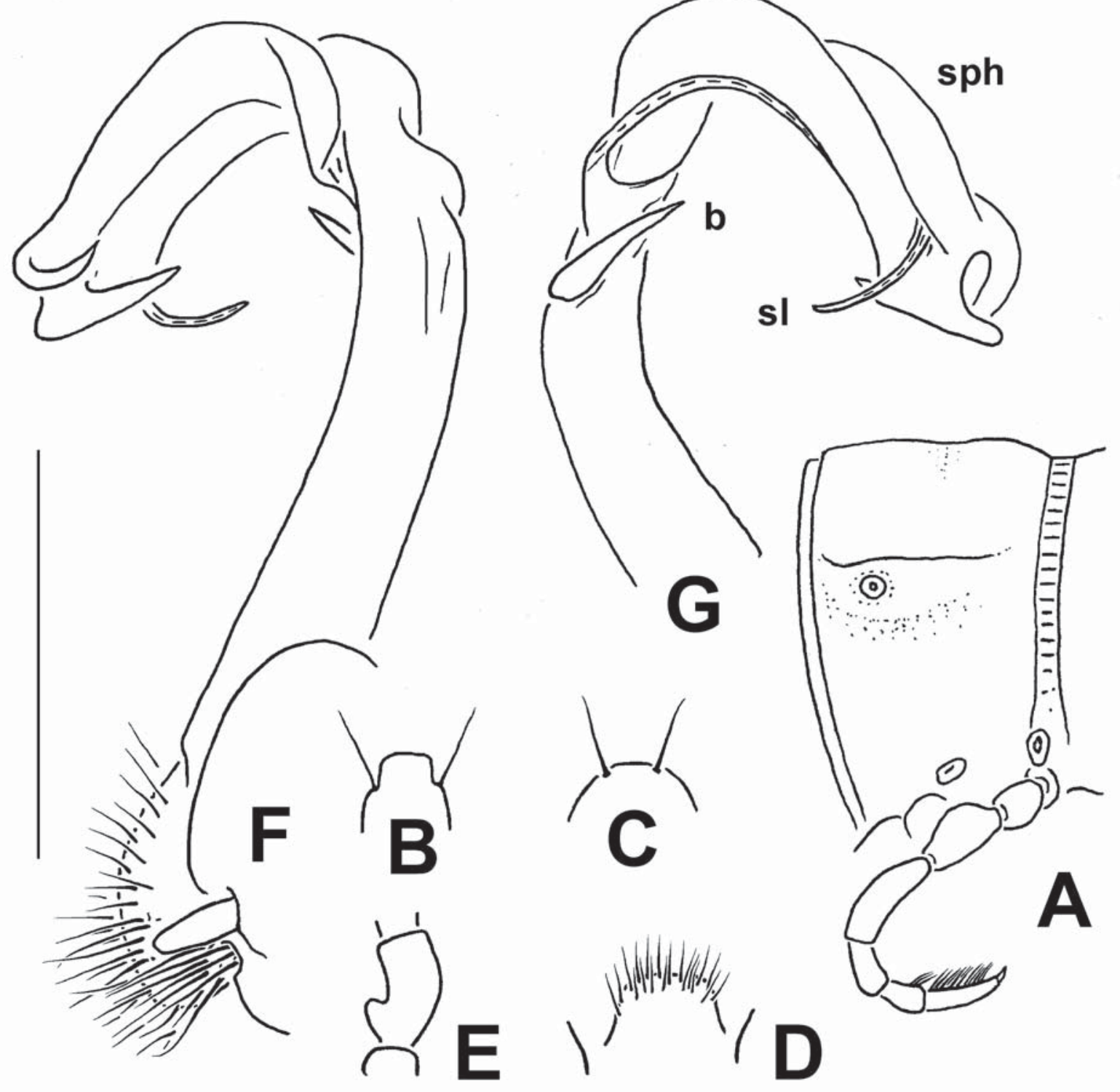

Fig. 13. Beronodesmus gorkhalis sp.n., $\mathrm{O}^{T}$ holotype. A - segment 10, lateral view; B - epiproct, dorsal view; C - hypoproct, ventral view; D - sternal lobe between coxae 4, ventral view; E - femur 1, lateral view; F \& G - right gonopod, mesal and lateral views, respectively. Scale bar: 1.0 (A-E) \& $0.5 \mathrm{~mm}(\mathrm{~F}, \mathrm{G})$.

Рис. 13. Beronodesmus gorkhalis sp.n., голотип О’. А - сегмент 10, сбоку; В - эпипрокт, сверху; С - гипопрокт, снизу; D стернальная пластина между тазиками 4, сзади; Е - бедро 1, сбоку; F и $\mathrm{G}$ - правый гонопод, соответственно изнутри и сбоку. Масштаб: 1,0 (A-E) и 0,5 мм (F, G).

At least one species from northern Vietnam [Jeekel, 1953]. The identity of T. jeekeli Nguyen, 2011, also from northern Vietnam, has been questioned [Golovatch, 2014]. Whereas T. flexipes Jeekel, 1953 does show pleurosternal carinae [Jeekel, 1953], these can hardly be described as conspicuous in $T$. jeekeli [cf. Nguyen, 2011]. In addition, the gonopod of $T$. jeekeli is depicted as having a postfemoral sulcus. However, the attribution of these two species to Chamberliniini, if not to the same genus, is currently beyond doubt.
Beronodesmus gorkhalis sp.n.

Figs $12 \& 13$.

HOLOTYPE O' (SMF), Nepal, Gorkha Distr., Chuling Khola, Djongshi Kharka, 3050-3400 m a.s.1., mixed forest, 5.08.1983, leg. J. Martens \& W. Schawaller.

PARATYPES: $1 \sigma^{7}, 1$ ㅇ (SMF), $1 \sigma^{7}$ (ZMUM $\rho 2579$ ), same data, together with holotype.

DIAGNOSIS. Differs from congeners by a rudimentary distofemoral process a and a rather short, spiniform b (see also Key below). 


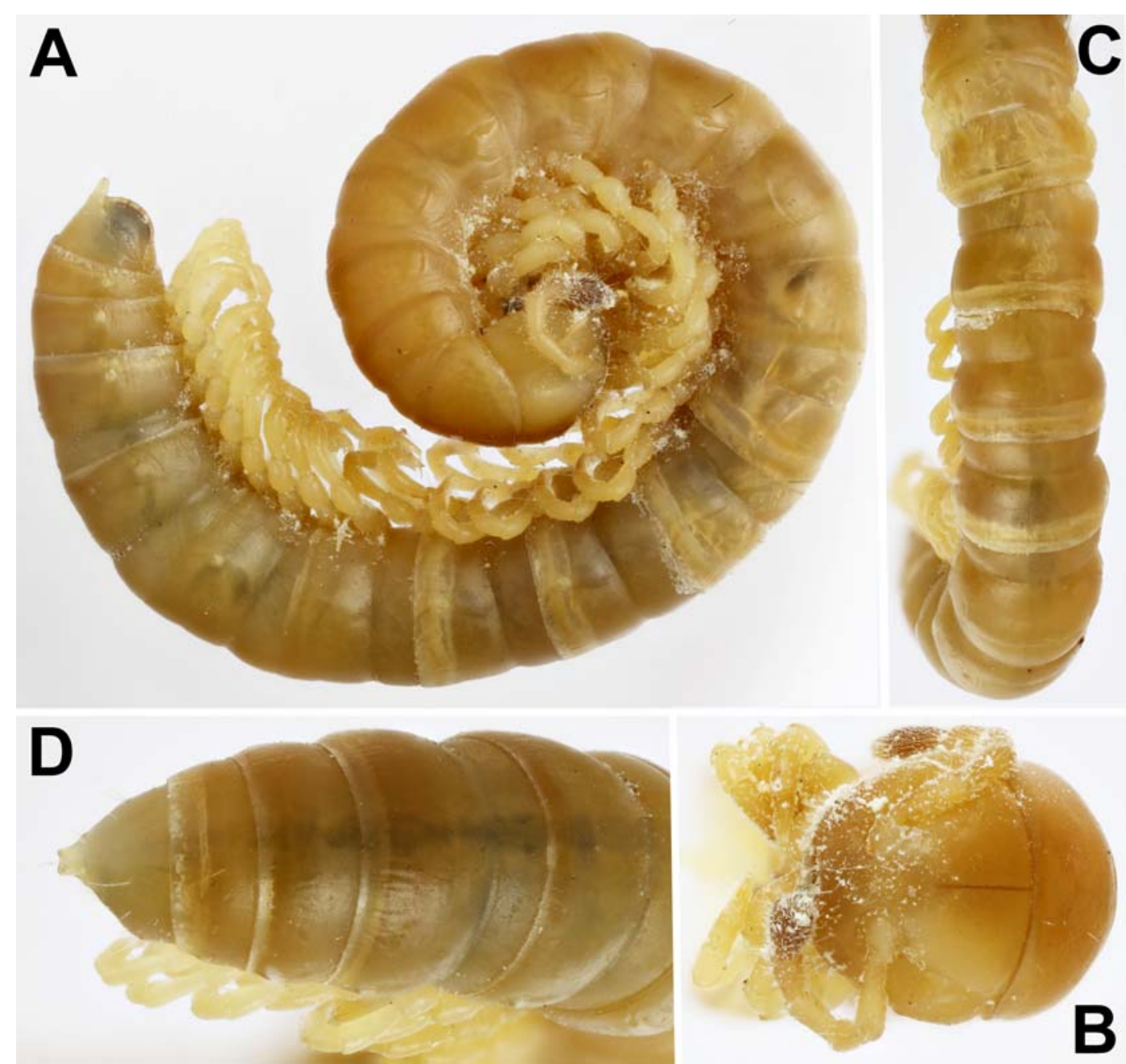

Fig. 14. Beronodesmus longispinus sp.n., Ơ holotype. A - habitus, lateral view; B-D - anterior, middle and posterior parts of body, frontal, dorsal and dorsal views, respectively. Pictures by K. Makarov, taken not to scale.

Рис. 14. Beronodesmus longispinus sp.n., голотип О'. А - общий вид, сбоку; В-D - передняя, средняя и задняя части тела, соответственно спереди, сверху и сверху. Фотографии К. Макарова, без масштаба.

NAME. To emphasize the terra typica; adjective.

DESCRIPTION. Length ca 12-13 $\left(\mathrm{O}^{7}\right)$ or $16 \mathrm{~mm}$ $(+)$, width of midbody pro- and metazonae $0.9-1.0$ and $1.0-1.1\left(\sigma^{7}\right)$ or 1.4 and $1.5 \mathrm{~mm}(+)$, respectively. General coloration in alcohol pallid, only sometimes anterior half of body slightly brown-yellowish (Fig. 12) while antennomere 6 faintly brownish.

All characters as in B. minutus sp.n., except as follows.

In width, collum $<$ segment $2=3<$ head $=4<5$ 16; thereafter body gradually tapering. Body surface generally smooth and shining, only metazonae below paraterga and rear halves of metaterga usually very finely rugulose (Fig. 12A, C, D). Sometimes highly superficial traces of transverse metatergal sulci visible (Fig. 13A). Tergal setae short, almost completely abraded, about $1 / 3$ as long as metatergite length, no pattern traceable. Pleurosternal carinae evident and toothless, well-visible only in segment 2, thereafter thin lines traceable until segment 10. Epiproct (Figs 12A, D,
13B) rather long, digitiform, subtruncate at apex, subapical lateral papillae rather small and well removed from tip. Hypoproct (Fig. 13C) semi-circular, caudal $1+1$ setae clearly separated, not borne on knobs, placed at caudal margin.

A single, roundly subtrapeziform, setose lobe between coxae 4 (Fig. 13D). Legs densely setose ventrally, slightly incrassate in $\sigma^{7}$ compared to + , short and stout, ca $1.0-1.1\left(\sigma^{7}\right)$ or $0.8-0.9(+)$ times as long as midbody height (Figs 12, 13A), prefemora moderately swollen laterally (Figs 12A, 13A), each femur 1 with a very strong, setose adenostyle (Fig. 13E); tarsal brushes present (Fig. 11A), gradually thinning out towards a few last legs $\left(\mathrm{O}^{7}\right)$.

Gonopods (Fig. 13F, G) rather simple, elongate and subfalcate; femorite relatively simple, untwisted, suberect, not enlarged distad, lacking a dorsal outgrowth, but bearing a slender, rather short, apically acuminate, ventral spine (b) before a cingulum setting off a slender, subcircular, lamellar acropodite $=$ sole- 


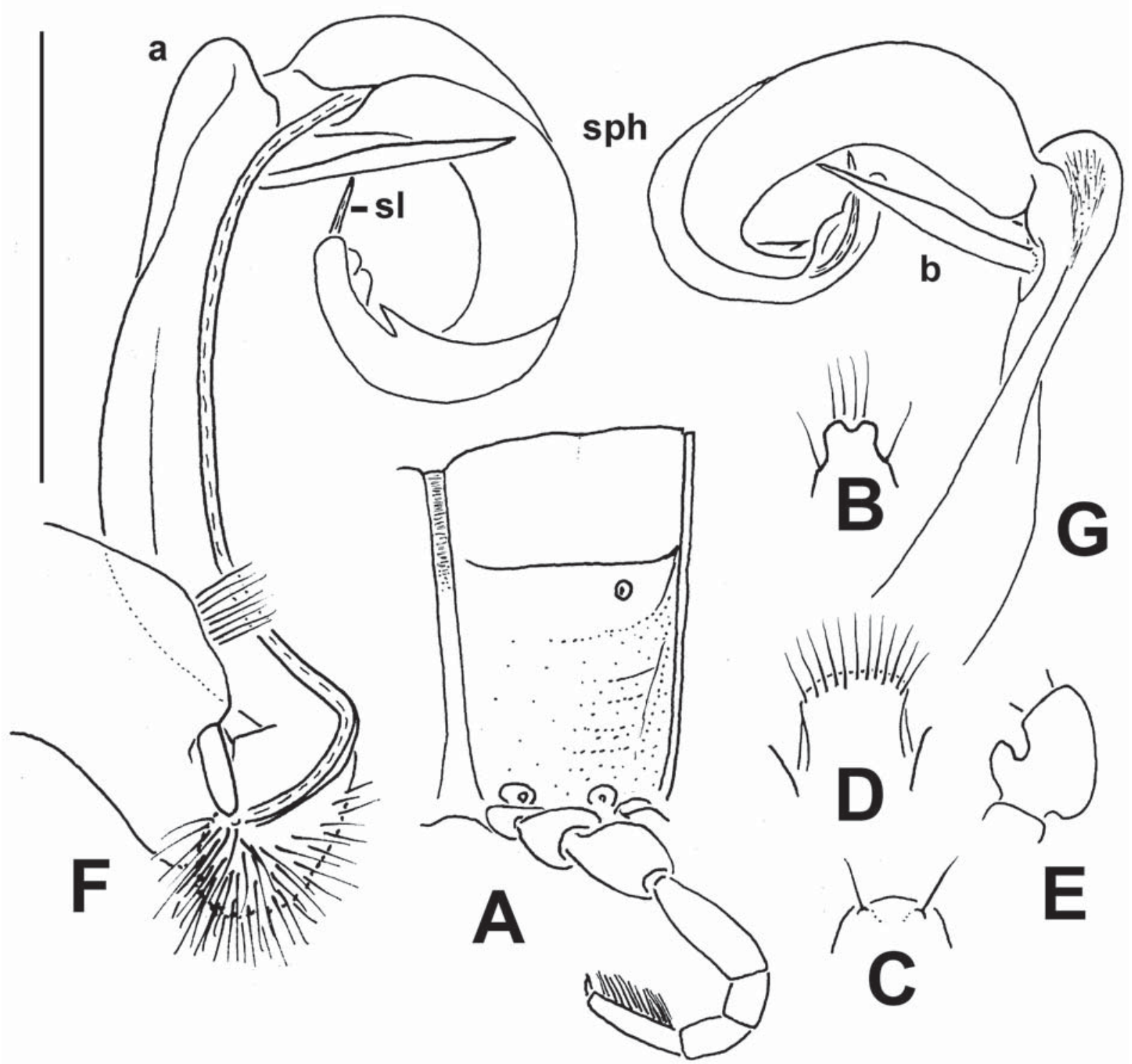

Fig. 15. Beronodesmus longispinus sp.n., $\mathrm{O}^{7}$ holotype. A - segment 10, lateral view; B - epiproct, dorsal view; C - hypoproct, ventral view; D - sternal lobe between coxae 4, ventral view; E - femur 1, lateral view; F \& G - left gonopod, mesal and lateral views, respectively. Scale bar: 2.0 (A-E) \& $1.0 \mathrm{~mm}(\mathrm{~F}, \mathrm{G})$.

Рис. 15. Beronodesmus longispinus sp.n., голотип $\mathrm{O}^{7}$. А - сегмент 10, сбоку; В - эпипрокт, сверху; С - гипопрокт, снизу; D - стернальная пластина между тазиками 4 , сзади; Е - бедро 1 , сбоку; $\mathrm{F}$ и $\mathrm{G}$ - левый гонопод, соответственно изнутри и сбоку. Масштаб: 2,0 (A-E) и 1,0 мм (F, G).

nophore (sph), the latter nearly as long as femorite, bifid distally, both apical branches being spiniform; seminal groove running entirely on mesal face of femorite, moving onto a long flagelliform solenomere (sl) at base of $\mathbf{b}$; both sph and sl subequal in length.

\section{Beronodesmus longispinus sp.n.}

Figs 14-16.

HOLOTYPE $\sigma^{7}$ (SMF), Nepal, Taplejung Distr., above Walungchung Gola, open Abies forest, Rhododendron bush, 3600-3800 m a.s.1., 21.05.1988, leg. J. Martens \& W. Schawaller.

PARATYPES: $2 \sigma^{\top} \sigma^{\top}, 2$ 우 (SMF), $1 \sigma^{\top}, 1$ ( 1 (ZMUM $\rho 2580$ ), same data, together with holotype; $1 \sigma^{7}$ (incomplete, lacking segments 10-20) (SMF), Myagdi Distr., southern Dhaulagiri Himal,
Dhorpatan, $3000 \mathrm{~m}$ a.s.1., Pinus-Abies forest, 23.05.1973, leg. J. Martens.

NON-TYPES: $10^{7}$ (SMF), Taplejung Distr., S of Gunsa, 3900 $\mathrm{m}$ a.s.l., Abies forest, Berlese extraction, 10.09.1983, leg. J. Mar-

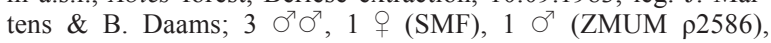
Taplejung Distr., Lassetham Kharka, NW of Yamputhin, 3300$3500 \mathrm{~m}$ a.s.1., mature Abies-Rhododendron forest, 6-9.05.1988, leg. J. Martens \& W. Schawaller.

DIAGNOSIS. Differs from congeners by the long and slender distoventral spine $\mathbf{b}$ of the gonopod femorite, coupled with a short lobuliform a (see also Key below).

NAME. To emphasize the long distoventral spine in the gonopod femorite; adjective.

DESCRIPTION. Length of samples from above Walungchung Gola ca 16-17 ( $\left.\sigma^{7}\right)$ or 18-19 mm (), 

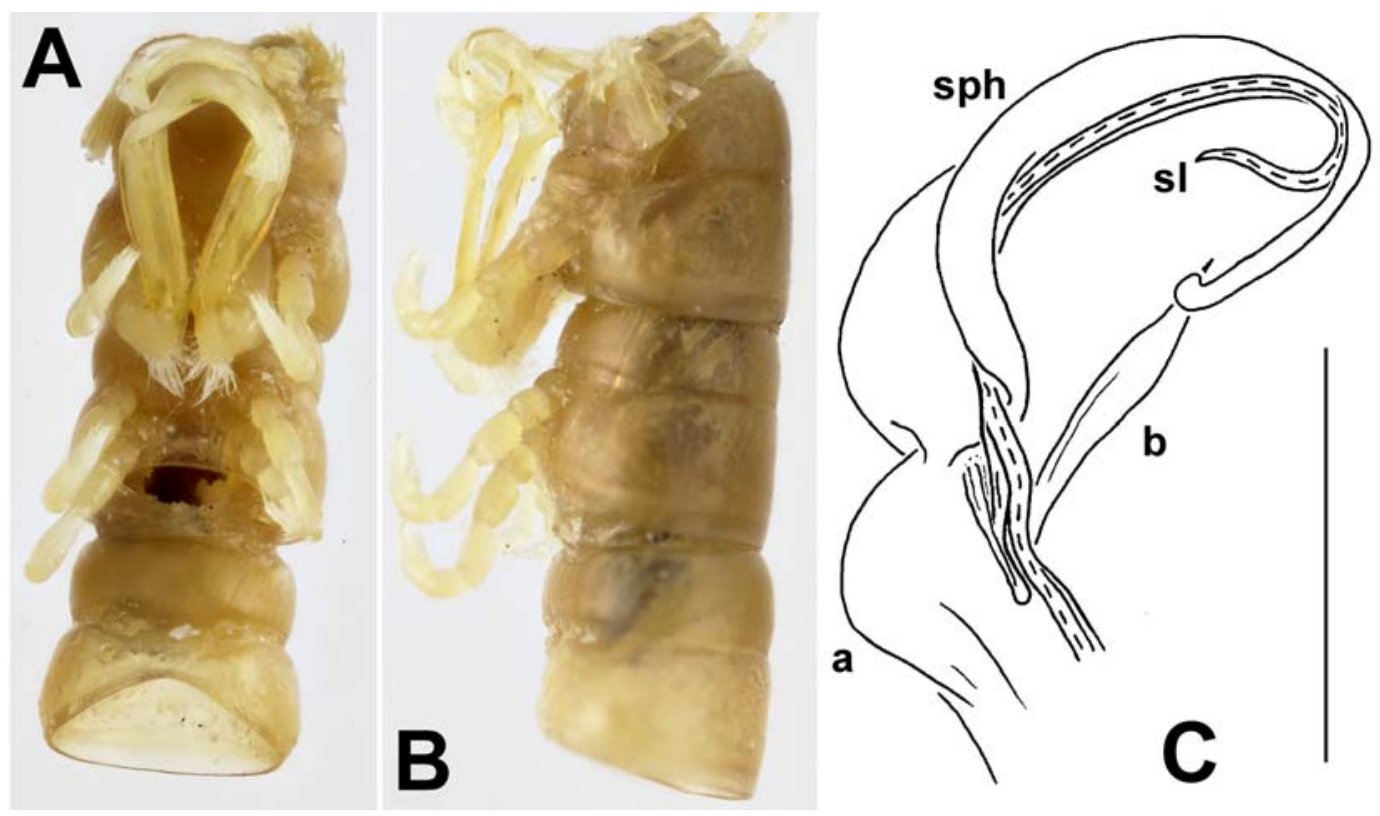

Fig. 16. Beronodesmus longispinus sp.n., O paratype from Dhorpatan. A \& B - segments 7-9, ventral and lateral views, respectively; $\mathrm{C}$ - distal half of left gonopod, mesal view. Pictures by K. Makarov, taken not to scale (A \& B); scale bar: $0.5 \mathrm{~mm}$ (C).

Рис. 16. Beronodesmus longispinus sp.n., паратип О из Dhorpatan А и В - сегменты 7-9, соответственно снизу и сбоку; С дистальная половина левого гонопода, изнутри. Фотографии К. Макарова, без масштаба (А и В); масштаб: 0,5 мм (C).

Fig. 17. Beronodesmus latispinosus sp.n., OT $^{7}$ holotype. A habitus, lateral view; B \& $\mathrm{C}-$ anterior + posterior and middle parts of body, dorsal views. Pictures by K. Makarov, taken not to scale.

Pис. 17. Beronodesmus latispinosus sp.n., голотип О'. А общий вид, сбоку; В и С - передняя + задняя и средняя части тела, сверху. Фотографии К. Макарова, без масштаба.
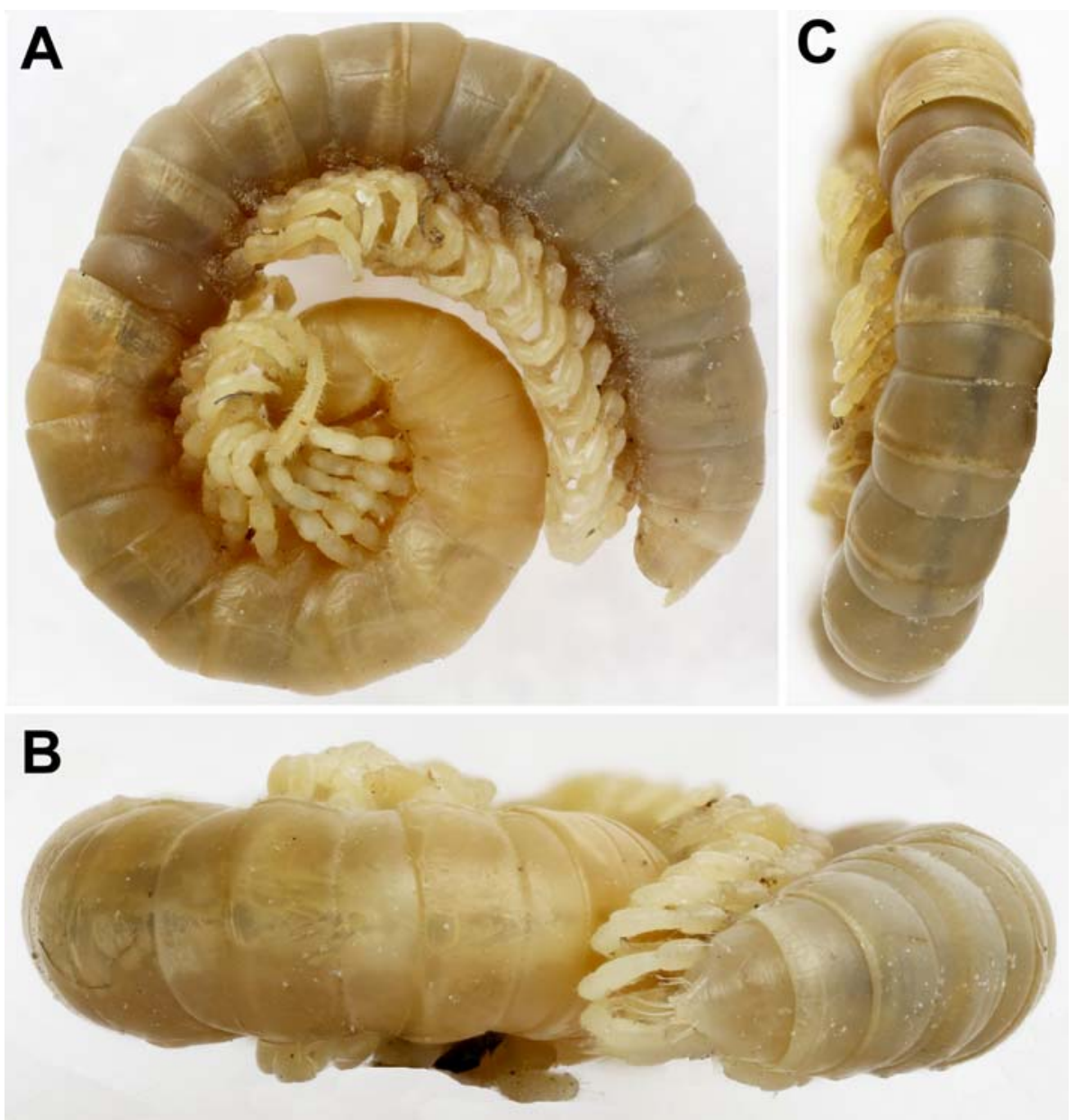


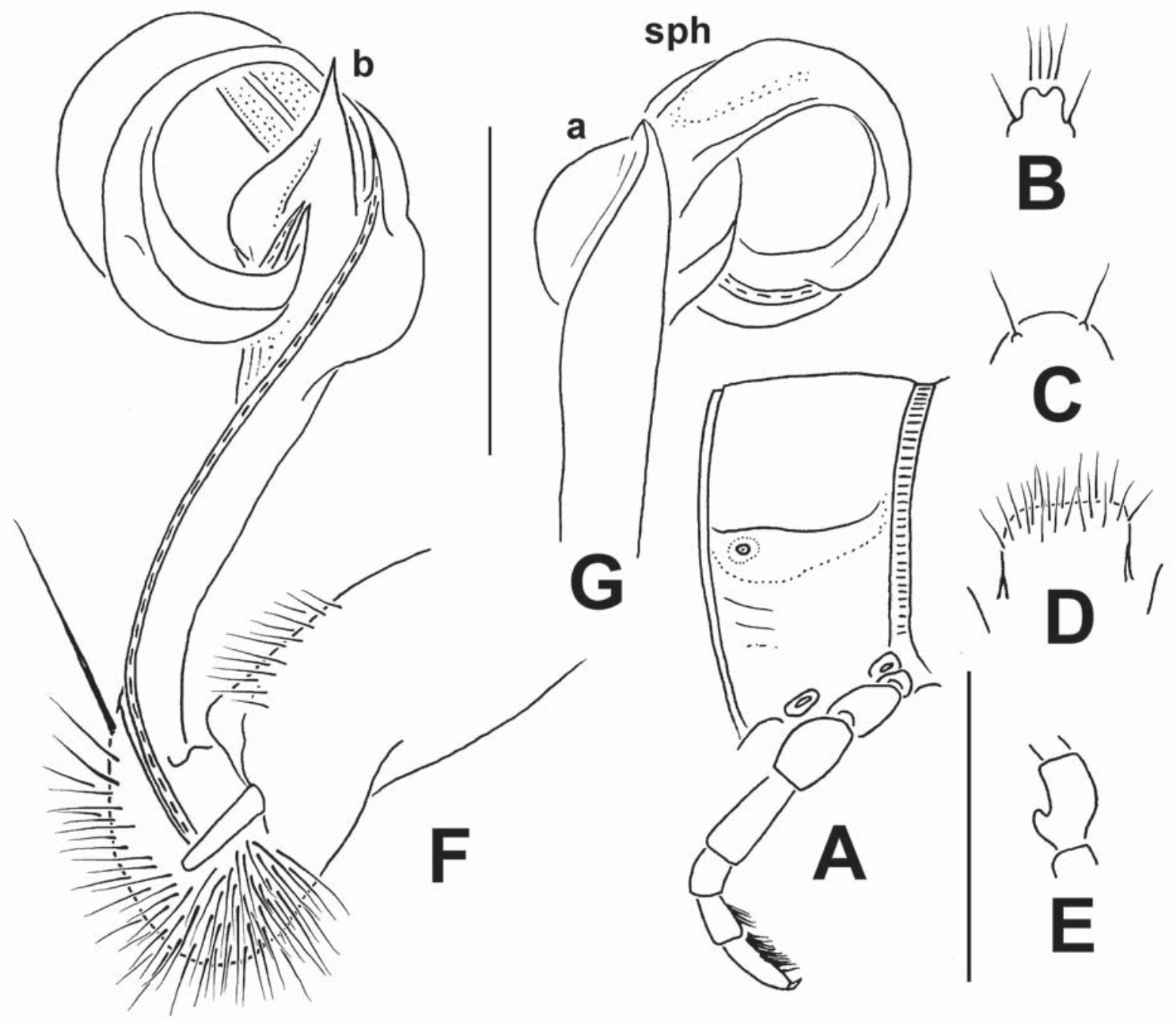

Fig. 18. Beronodesmus latispinosus sp.n., O $^{\top}$ holotype. A - segment 10, lateral view; B - epiproct, dorsal view; C - hypoproct, ventral view; D - sternal lobe between coxae 4, ventral view; E - femur 1, lateral view; F \& G - right gonopod, mesal and lateral views, respectively. Scale bar: 1.0 (A-E) \& $0.5 \mathrm{~mm}(\mathrm{~F}, \mathrm{G})$.

Рис. 18. Beronodesmus latispinosus sp.n., голотип О7. А - сегмент 10, сбоку; В - эпипрокт, сверху; С — гипопрокт, снизу; $\mathrm{D}$ - стернальная пластина между тазиками 4, сзади; Е - бедро 1, сбоку; F и $\mathrm{G}$ - правый гонопод, соответственно изнутри и сбоку. Масштаб: 1,0 (A-E) и 0,5 мм (F, G).

width of midbody pro- and metazonae $1.4-1.5$ and $1.5-1.6\left(O^{7}\right)$ or 1.8 and $1.9 \mathrm{~mm}(+)$, respectively. Width of $\sigma^{7}$ paratype from Dhorpatan ca 1.0 and $1.1 \mathrm{~mm}$ on midbody pro- and metazonae, respectively. Length of non-type $\sigma^{7}$ from $\mathrm{S}$ of Gunsa ca $15 \mathrm{~mm}$, width of midbody pro- and metazonae $1.4-1.5 \mathrm{~mm}$, respectively. Body of non-types $\left(\sigma^{7} \sigma^{7},+\right.$ ) from Lassetham Kharka much larger, ca 27-28 mm long, and 1.7-1.8 and 1.9-2.0 mm wide on midbody pro- and metazonae, respectively. General coloration of types in alcohol light yellowish, only sometimes anterior half of body yellow-brownish (Fig. 14) while antennomere 6 brownish. Coloration of non-types from Lassetham Kharka uniformly dark brown with lighter yellow-brown legs and blackish brown antennomeres 6 and 7 .

All characters as in $B$. minutus sp.n., except as follows.
In width, collum $<$ segment $2=3<$ head $=4<5$ 16 ; thereafter body gradually tapering. Body surface generally smooth and shining, only metazonae below paraterga sometimes microgranulate and rugulose while rear halves of metaterga usually more finely rugulose (Figs 14D, 15A). Sometimes highly superficial traces of transverse metatergal sulci visible (Fig. 15A). Tergal setae short, almost completely abraded, about $1 / 3$ as long as metatergite length, pattern traceable as $2+2$ setae arranged in a single transverse row in about anterior $1 / 3$ of metaterga. Pleurosternal carinae well-visible only in segment 2, toothless, thereafter thin lines traceable until about segment 7 or $8\left(O^{7}\right)$. Epiproct (Figs 14D, 15A) rather long, digitiform, deeply emarginate at apex, subapical lateral papillae small and well removed from tip. Hypoproct (Fig. 15C) semi-circular, caudal 1+1 setae 

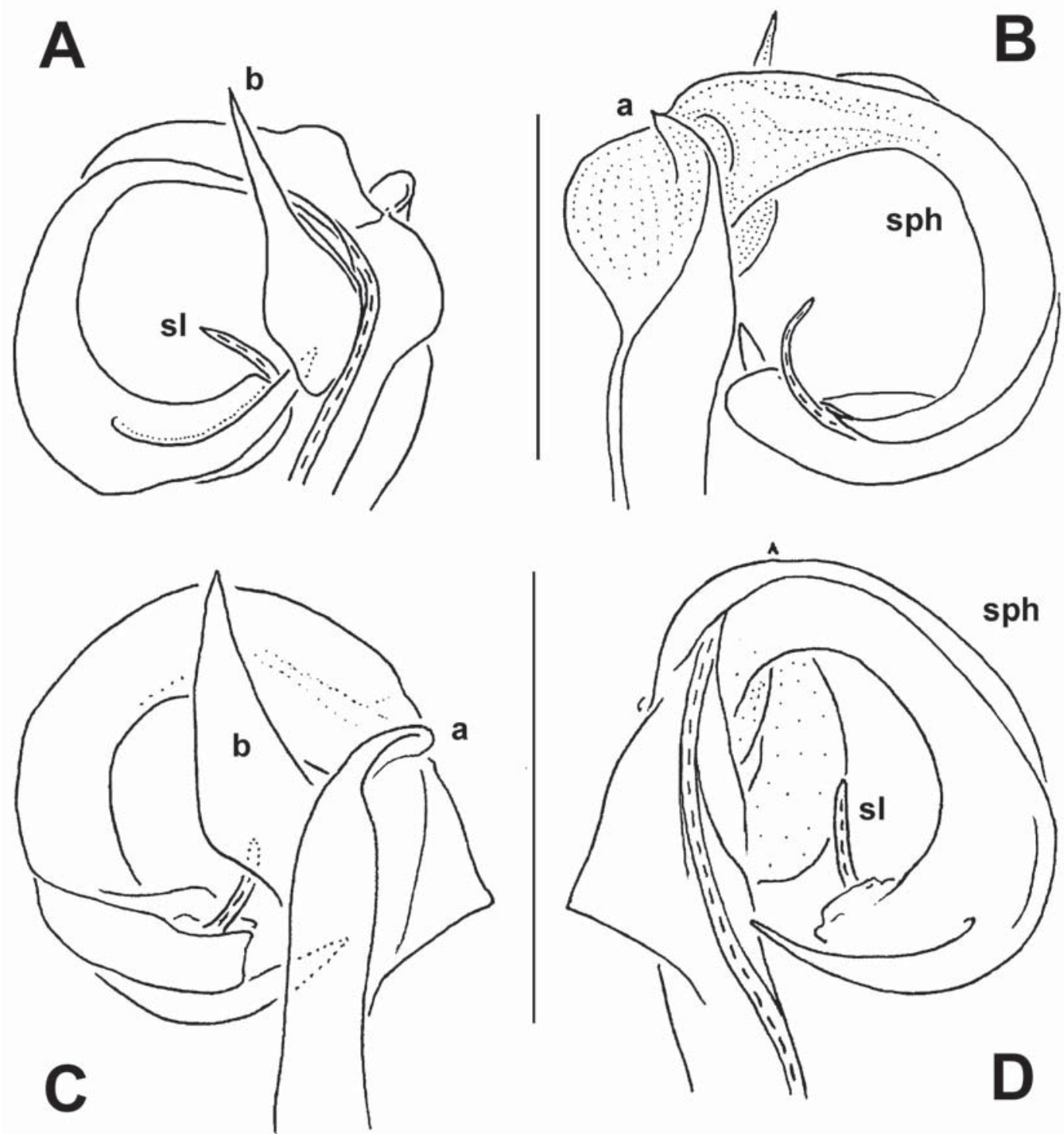

Fig. 19. Beronodesmus latispinosus sp.n., O $^{7}$ paratypes from between Mure \& Hurure (A \& B) and from Chichila (C \& D), distal gonopod half, mesal, lateral, lateral and submesal views, respectively. Scale bars: $0.5 \mathrm{~mm}$.

Pис. 19. Beronodesmus latispinosus sp.n., паратипы $0^{7} \bigcirc^{7}$ из между Mure и Hurure (А и В) и из Chichila (C и D), дистальная половина гонопода, соответственно изнутри, сбоку, сбоку и почти изнутри. Масштаб: 0,5 мм.

clearly separated, borne on minute knobs, placed near caudal margin.

A single, roundly subtrapeziform, setose lobe between coxae 4 (Fig. 15D). Legs densely setose ventrally, slightly incrassate in $\sigma^{7}$ compared to 9 , short and stout, ca 1.0-1.1 $\left(\sigma^{7}\right)$ or $0.8-0.9(+)$ times as long as midbody height (Figs 12, 13A), prefemora moderately swollen laterally (Figs 14A, 15A), each femur 1 with a very strong, setose adenostyle (Fig. 15E); tarsal brushes present (Fig. 15A), gradually thinning out towards a few last legs $\left(O^{7}\right)$.

Gonopods (Figs 15F, G, 16) rather simple, elongate and subfalcate; femorite relatively simple, untwisted, only slightly curved, not enlarged distad, with a dorsal, rounded, lobe-shaped outgrowth (a) and a very slender, normally very long, apically acuminate, ventral spine (b) before a cingulum setting off a subcircular lamellar acropodite $=$ solenophore (sph), the latter nearly as long as femorite, about 2 times longer than $\mathbf{b}$, its apical part being subspiniform; seminal groove running entirely on mesal face of femorite, moving onto a long flagelliform solenomere (sl) at base of b; both sph and sl subequal in length.

REMARK. The solenophore of the non-type $\sigma^{7}$ from $\mathrm{S}$ of Gunsa is a little different in showing a slightly shorter spine b (ca 1/3 the length of $\mathbf{s p h}$ ), possibly representing a local variety.

\section{Beronodesmus latispinosus sp.n.}

Figs 17-19.

HOLOTYPE $\sigma^{\gamma}$ (SMF), Nepal, Taplejung Distr., Lassetham Kharka, NW of Yamputhin, 3300-3500 m a.s.1., mature Abies- 

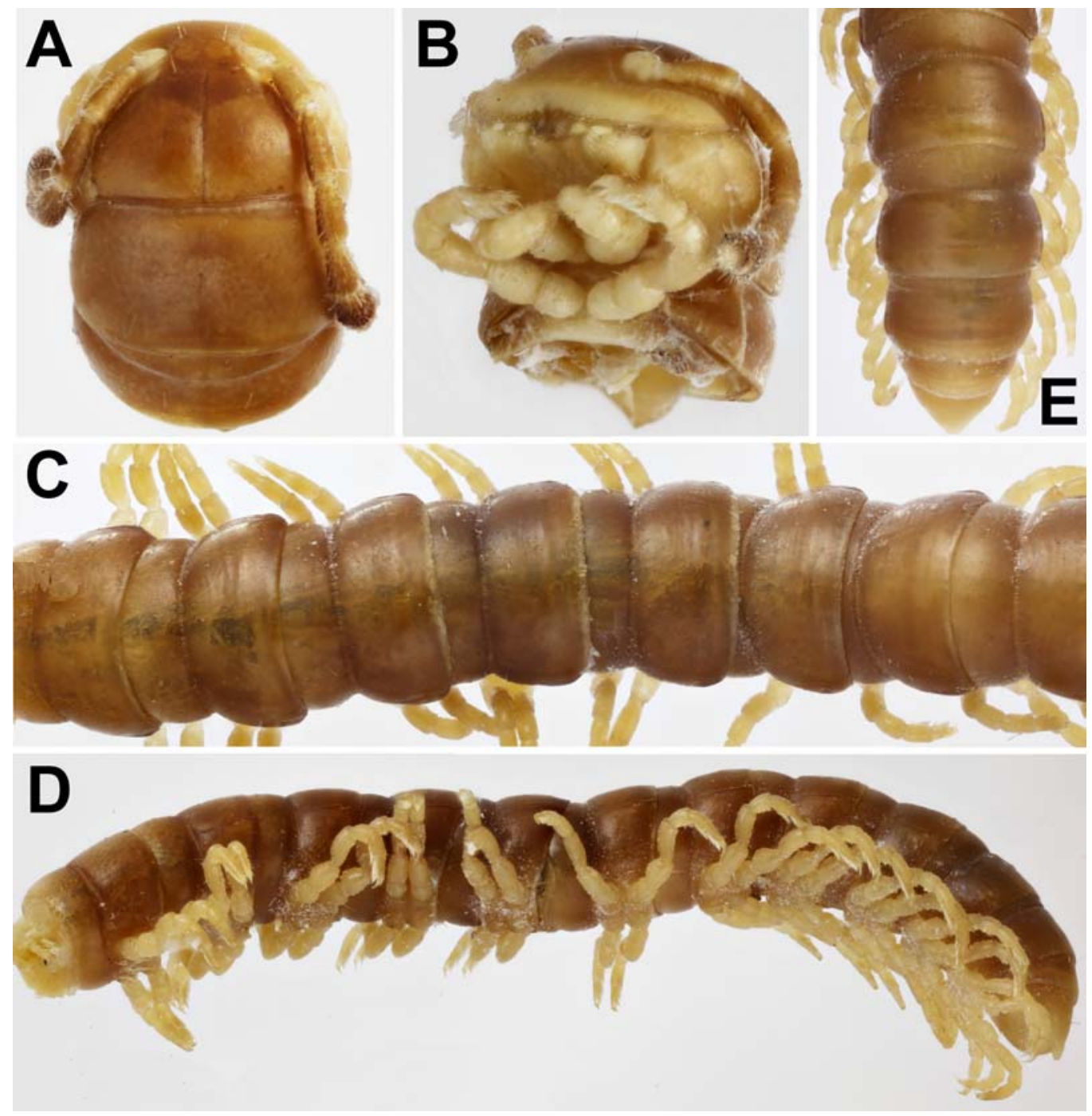

Fig. 20. Beronodesmus curtispinus sp.n., $\sigma^{\top}$ holotype. A \& B - head, collum and segment 2, dorsal and ventral views, respectively; $\mathrm{C}$ - midbody segments, dorsal view; D - posterior half of body, lateral view; E - caudal part of body, dorsal view. Pictures by K. Makarov, taken not to scale.

Рис. 20. Beronodesmus curtispinus sp.n., голотип О7. А и В - голова, коллум и сегмент 2, соответственно сверху и снизу; С среднетуловищные сегменты, сверху; D — задняя половина тела, сбоку; Е — задняя часть тела, сверху. Фотографии К. Макарова, без масштаба.

Rhododendron forest, 6-9.05.1988, leg. J. Martens \& W. Schawaller.

PARATYPES: 2 우, 1 subadult + (SMF), same data, together with holotype; $10^{7}$ (incomplete, lacking segments 10-20) (SMF), Myagdi Distr., southern Dhaulagiri Himal, Dhorpatan, 3000 m a.s.l., Pinus-Abies forest, 23.05.1973, leg. J. Martens; 3 O $^{7} \sigma^{7}, 4$ 우, 1 juv. + (SMF), 1 O 1 q (ZMUM p2581), Sankhua Sabha District, Arun Valley, Chichila, 1900-2000 m a.s.1., Quercus forest, bushes near village, 18-20.06.1988; $3 \bigcirc^{7} \sigma^{7}, 6$ 우, 4 juv. (SMF), $10^{7}, 1$ ( 1 (ZMUM @2582), Sankhua Sabha District, Arun Valley, between Mure \& Hurure, 2050-2150 m a.s.1., mixed broadleaved forest, bushes near village, 8-17.06.1988, all leg. J. Martens \& W. Schawaller.

DIAGNOSIS. Differs from congeners by the particularly broad and moderately long distoventral spine b on the gonopod femorite (see also Key below).

NAME. To emphasize the parabasally broad distoventral spine $\mathbf{b}$ on the gonopod femorite; adjective.

DESCRIPTION. Length ca 13-15 $\left(\mathrm{O}^{7}\right)$ or 16-17 $\mathrm{mm}(+)$, width of midbody pro- and metazonae $1.1-1.3$ and $1.2-1.5 \mathrm{~mm}\left(\sigma^{7}\right)$ or $1.6-1.7$ and $1.7-1.8 \mathrm{~mm}\left({ }_{+}\right)$, respectively. Holotype ca $13 \mathrm{~mm}$ long, 1.1 and $1.2 \mathrm{~mm}$ wide on midbody pro- and metazonae, respectively. General coloration in alcohol light yellowish, only sometimes anterior half of body light yellow-grey to brownish (Fig. 17) while distal $1 / 4$ of antennomere 6 brownish.

All characters as in B. minutus sp.n., except as follows.

In width, collum $=$ segment $4<2=3<$ head $=$ segments 5-16; thereafter body gradually tapering. Body surface generally smooth and shining, only metazonae below paraterga sometimes microgranulate and rugulose while rear halves of metaterga usually more finely rugulose (Figs 17A, 18A). Tergal setae short, almost completely abraded, about $1 / 3$ as long as metatergite length, pattern untraceable. Paraterga delimited by a sharp sulcus not only dorsally, but poreless 


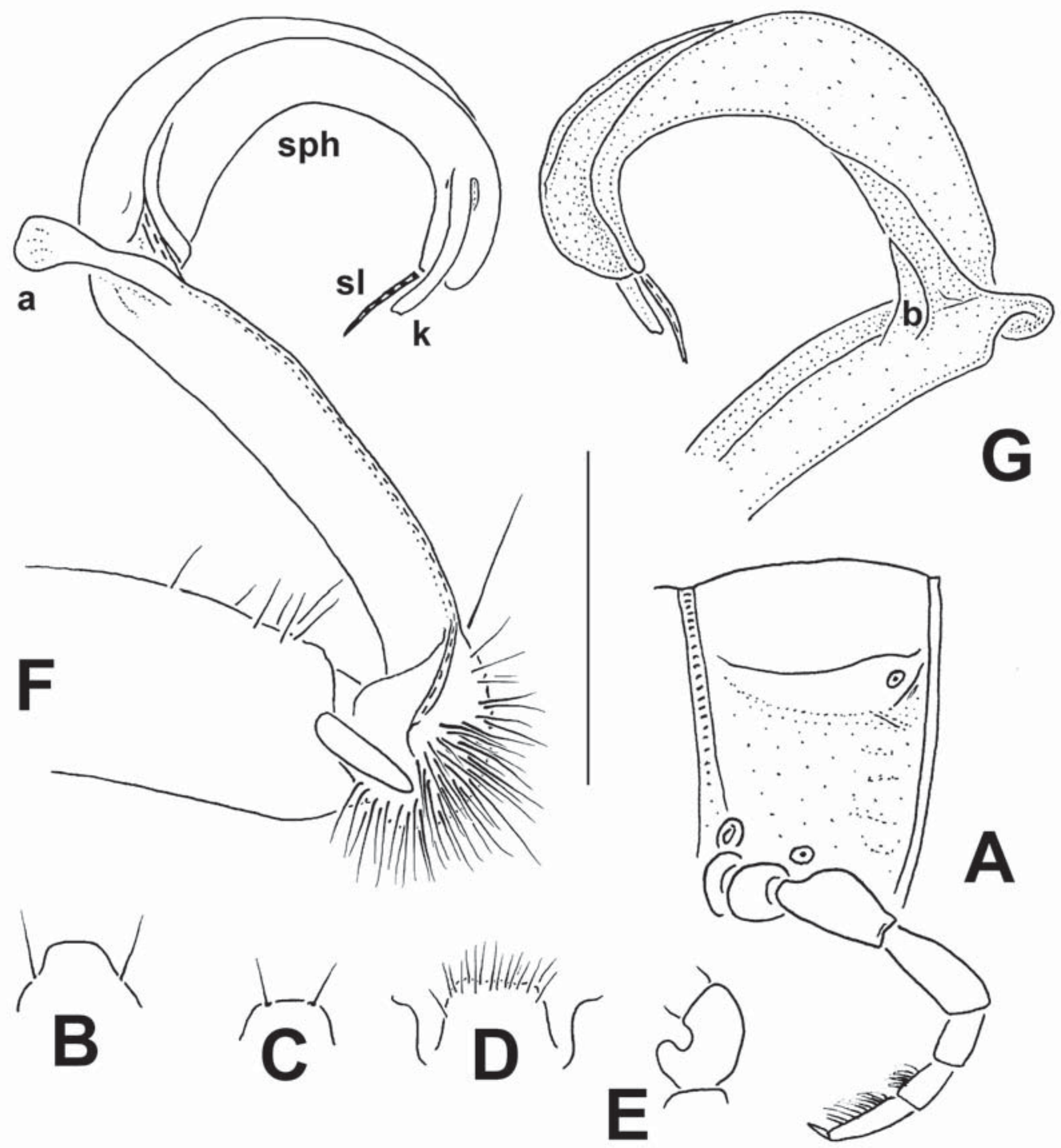

Fig. 21. Beronodesmus curtispinus sp.n., $\sigma^{7}$ holotype. A - segment 10, lateral view; B - epiproct, dorsal view; C - hypoproct, ventral view; D - sternal lobe between coxae 4, ventral view; E - femur 1, lateral view; F \& G - left gonopod, mesal and lateral views, respectively. Scale bar: 1.0 (A-E) \& $0.5 \mathrm{~mm}(\mathrm{~F}, \mathrm{G})$.

Рис. 21. Beronodesmus curtispinus sp.n., голотип О7. A - сегмент 10, сбоку; В - эпипрокт, сверху; C - гипопрокт, снизу; D стернальная пластина между тазиками 4, сзади; E - бедро 1 , сбоку; F и $\mathrm{G}$ - левый гонопод, соответственно изнутри и сбоку. Масштаб: 1,0 (A-E) и 0,5 мм (F, G).

ones sometimes by a faint sulcus ventrally as well. Pleurosternal carinae well-visible only in segment 2, toothless, thereafter at most thin lines traceable on a few following segments $\left(O^{7}\right)$. Epiproct (Figs 17B, 18B) rather long, digitiform, deeply emarginate at apex, subapical lateral papillae evident and well removed from tip. Hypoproct (Fig. 18C) semi-circular, caudal 1+1 setae clearly separated, borne on minute knobs, placed near caudal margin.

A single, roundly subtrapeziform, setose lobe between coxae 4 (Fig. 18D). Legs densely setose ventrally, slightly incrassate in $\sigma^{r}$ compared to $q$, short and stout, ca 1.0-1.2 $\left(\mathrm{O}^{7}\right)$ or $0.8-0.9(+)$ times as long as midbody height (Figs 17, 18A), prefemora moderately swollen laterally (Figs 17A, 18A), each femur 1 with a very strong, setose adenostyle (Fig. 18E); tarsal and, partly, tibial brushes present (Fig. 18A), gradually thinning out towards a few last legs $\left(\mathrm{O}^{7}\right)$.

Gonopods (Figs 18F, G, 19) rather simple, elongate and falcate; femorite relatively simple, untwisted, slightly curved, enlarged only distally, with an inconspicuous, dorsal, rounded, lobe-shaped outgrowth (a) and a large, basally broad, rather short, apically acuminate, ventral spine (b) before a cingulum setting off a circular lamellar acropodite (= solenophore, $\mathbf{s p h}$ ), the latter nearly as long as femorite, ca 2-3 times as long as $\mathbf{b}$, its apical part being unequally bifid; seminal groove running entirely on mesal face of femorite, moving onto a 

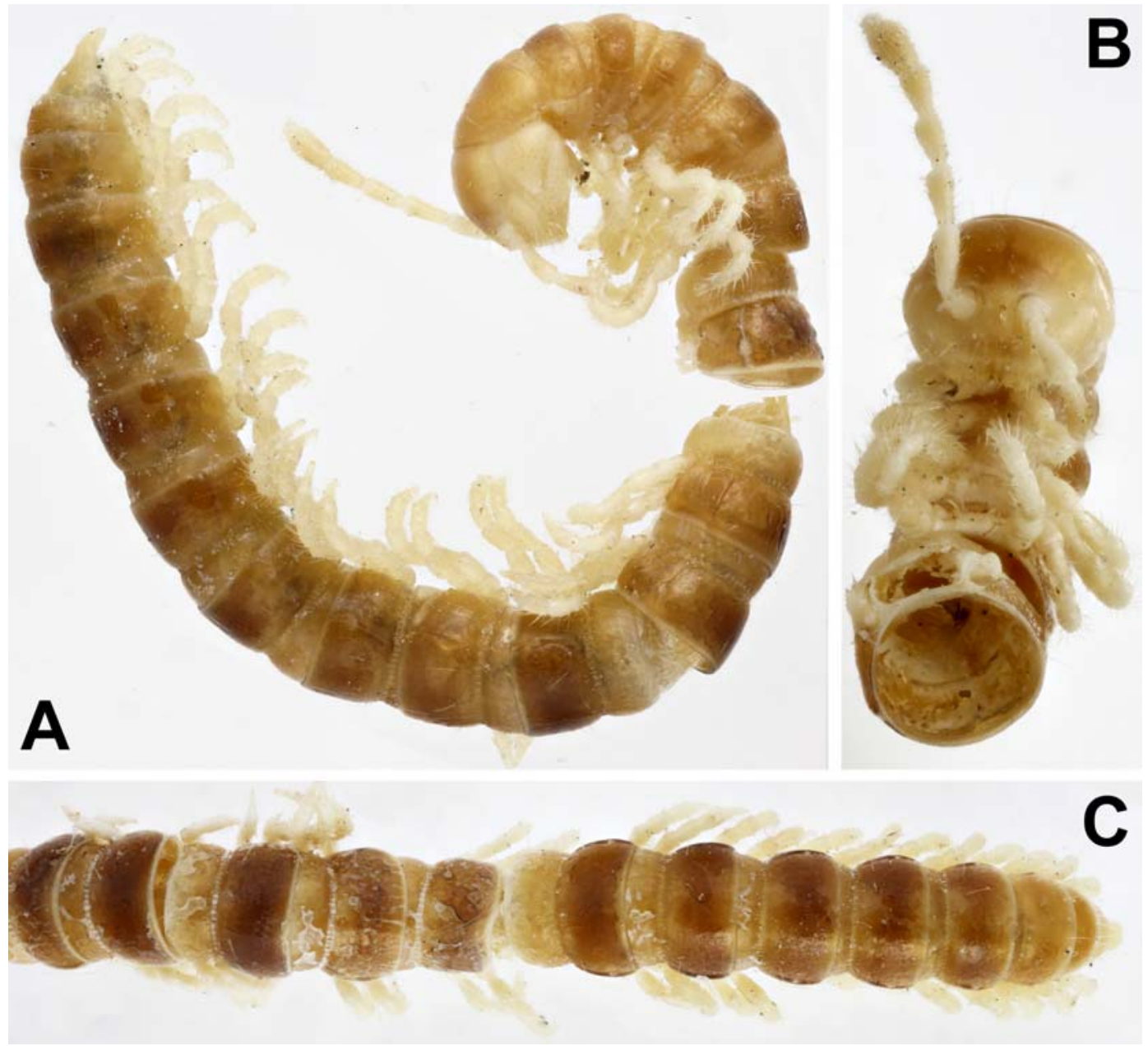

Fig. 22. Beronodesmus sinuatospinus sp.n., $\mathrm{O}^{7}$ holotype. A - habitus, lateral view; B - anterior part of body, ventral view; C segments $8-20$, dorsal view. Pictures by K. Makarov, taken not to scale.

Рис. 22. Beronodesmus sinuatospinus sp.n., голотип О‥ А - общий вид, сбоку; В - передняя часть тела, снизу; С - сегменты 8-20, сверху. Фотографии К. Макарова, без масштаба.

long flagelliform solenomere (sl) near base of $\mathbf{b}$; both sph and sl subequal in length.

REMARKS. The shape of the distofemoral projections of the gonopod slightly varies between the samples, likely representing a few local micropopulations at most.

\section{Beronodesmus curtispinus sp.n.}

Figs $20 \& 21$.

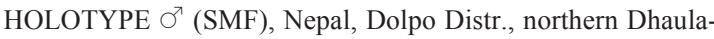
giri Himal, ascent to Pass Bagar La, 4500 m a.s.1., 16.06.1973, leg. J. Martens.

DIAGNOSIS. Differs from congeners by especially short, but stout distal processes of the gonopod femorite (see also Key below).

NAME. To emphasize the particularly short distal processes of the gonopod femorite; adjective.

DESCRIPTION. Length ca 17, width of midbody pro- and metazonae 1.4 and $1.5 \mathrm{~mm}$, respectively $\left(\sigma^{7}\right)$. General coloration in alcohol uniformly light brown, but epiproct, venter, and legs light brown-yellowish to yellow, only tips of antennae whitish.

All characters as in B. minutus sp.n., except as follows.

In width, collum $<$ head $=$ segment $4<2=3<5$ 16 ; thereafter body gradually tapering. Clypeolabral region sparsely setose, vertigial one showing only $1+1$ setae. Body surface generally smooth and shining (Fig. 20 ), only metazonae below paraterga sometimes microgranulate and rugulose while rear halves of metaterga usually more finely rugulose (Fig. 21A). Tergal setae very short, almost completely abraded, pattern untraceable. Paraterga delimited by a sharp sulcus only dorsally. Pleurosternal carinae rather well visible lobes only in segment 2 (Fig. 20B), toothless, thereafter very thin ridges or lines traceable until about segment 17 $\left(O^{7}\right)$. Epiproct (Figs 20E, 21B) subruncate at apex, subapical lateral papillae small, located rather near tip. Hypoproct (Fig. 21C) roundly subquadrate, caudal 1+1 setae clearly separated, not borne on knobs, placed at caudal margin. 
A single, roundly subtrapeziform, setose lobe between coxae 4 (Fig. 21D). Legs densely setose ventrally, incrassate $\left(\sigma^{7}\right)$, short and stout, ca 1.1-1.2 times as long as midbody height (Figs 20B-E, 21A), prefemora moderately swollen laterally (Fig. 21A), each femur 1 with a very strong, setose adenostyle (Fig. 21E); tarsal and, partly, distotibial brushes present (Fig. 21A), gradually thinning out towards telson, absent only from two last leg-pairs $\left(\mathrm{O}^{7}\right)$.

Gonopods (Fig. 21F, G) rather simple, clearly elongate and falcate; femorite relatively simple, untwisted, suberect, not enlarged distally, with a short, but evident, dorsal, rounded, spade-shaped outgrowth (a) and a similarly short, subspiniform, rather stout, apically acuminate, ventral spine (b) before a cingulum setting off a circular lamellar acropodite (= solenophore, $\mathbf{s p h}$ ), the latter about as long as femorite and unequally bifid, longer apical branchlet (k) being mesal, subflagelliform and narrowly rounded at tip; seminal groove running entirely on mesal face of femorite, moving onto a long flagelliform solenomere (sl) at base of $\mathbf{a}$; both $\mathbf{s p h}$ and sl subequal in length.

\section{Beronodesmus sinuatospinus sp.n.}

Figs $22 \& 23$.

HOLOTYPE O (SMF), Nepal, Ilam Distr., Mai Pokhari, 2150 2250 m a.s.1., 23-25.08.1983, leg. J. Martens \& B. Daams.

DIAGNOSIS. Differs from congeners by distal process $\mathbf{b}$ of the gonopod femorite being especially long, slender, sinuate and strongly appressed to the solenophore (see also Key below).

NAME. To emphasize the particularly long, slender and sinuate distal process $\mathbf{b}$ of the gonopod femorite; adjective.

DESCRIPTION. Length ca 11, width of midbody pro- and metazonae 0.9 and $1.0 \mathrm{~mm}$, respectively $\left(\sigma^{7}\right)$. General coloration in alcohol rather uniformly light brown, metazonae a little darker (brown), but epiproct, venter, legs and tip of antennae whitish.

All characters as in B. minutus sp.n., except as follows.

In width, segment $3=4<$ collum $=2=5<6-16<$ head; after segment 16 , body gradually tapering. Clypeolabral region sparsely setose, vertigial one showing only a few setae. Body surface generally smooth and shining (Fig. 22), only metazonae below paraterga microgranulate (Fig. 23A). Tergal setae unusually long, ca $1 / 3$ as long as metatergum, pattern as $2+2$ in a transverse pre-sulcus row, probably $3+3$ in a postsulcus one, almost completely retained in the former, always abraded and poorly traceable as insertion points in the latter (Fig. 23A). Transverse metatergal sulci at most barely visible, incomplete (Fig. 23A). Paraterga delimited by a sharp sulcus only dorsally (Figs 22A, 23A). Stricture dividing pro- and metazonae coarsely ribbed (Figs 22A, C, 23A). Pleurosternal carinae rather well visible lobes only in segment 2 (Fig. 22A), toothless, thereafter very thin ridges or lines traceable until about segment $7\left(\mathrm{O}^{7}\right)$. Epiproct (Fig. 23B) deeply emar- ginate at apex, subapical lateral papillae very small, well removed from tip. Hypoproct (Fig. 23C) semicircular, caudal $1+1$ setae clearly separated, not borne on knobs, placed at caudal margin.

A single, rounded, setose lobe between coxae 4 (Fig. 23D). Legs densely setose ventrally, somewhat incrassate, short and stout, ca 1.0-1.1 times as long as midbody height (Figs 22, 23A), prefemora not swollen laterally; each femur 1 with a rather strong, slender, setose adenostyle near base (Fig. 23E); tarsal brushes present until leg $10\left(\mathrm{O}^{7}\right)$ (Fig. 22A, B).

Gonopods (Fig. 23F, G) rather simple, very clearly elongate and distally falcate; femorite relatively simple, untwisted, very long and slender, suberect, only slightly enlarged distally, with a spiniform, subtransverse, short, dorsal outgrowth (a) and an unusually long, slender, sinuate, ventral procees b strongly appressed to solenophore (sph); the latter considerably shorter than femorite, branching subapically into a longer, narrowly rounded, mesal spine (k) and an expanded, roundly subtriangular, lateral lobe; sph about as long as a flagelliform solenomere (sl); seminal groove running entirely on mesal face of femorite, moving onto sl at base of $\mathbf{a}$.

\section{Beronodesmus distospinosus sp.n.}

Figs $24 \& 25$.

HOLOTYPE $0^{7}$ (SMF), Nepal, Taplejung Distr., Yamputhin, ascent to Pass Deorali, 2700-3080 m a.s.1., mixed mature forest, bamboo thickets, 16.05.1988, leg. J. Martens \& W. Schawaller.

PARATYPES: $1 \sigma^{7}$ (incomplete, lacking segments 12-20), 7 우 (SMF), $10^{\top}, 1$ ㅇ (ZMUM $\rho 2577$ ), same data, together with holotype; $1 \sigma^{r}$ (SMF), Nepal, Taplejung District, Omje Kharka in Omje Valley, NW of Yamputhin, 2300-2500 m a.s.1., mature mixed broadleaved forest, 1-6.05.1988, leg. J. Martens \& W. Schawaller.

DIAGNOSIS. Differs from congeners by distal process $\mathbf{b}$ of the gonopod femorite being long and lancetiform, coupled with the presence of a similar process $\mathbf{c}$ at about solenophore midway (see also Key below).

NAME. To emphasize the strong additional process $\mathbf{c}$ at about solenophore midway; adjective.

DESCRIPTION. Length ca $12-13\left(\sigma^{7}\right)$ or $15-16$ $\mathrm{mm}(+)$, width of midbody pro- and metazonae 1.0-1.1 and 1.1-1.2 $\mathrm{mm}\left(\sigma^{7}\right)$, or $1.4-1.5$ and $1.5-1.6 \mathrm{~mm}$, respectively $(+)$. General coloration in alcohol uniformly nearly pallid to light yellow-brown, metazonae and distal $1 / 3$ of antennomere 6 sometimes a little darker (light brown).

All characters as in B. minutus sp.n., except as follows.

In width, collum $=$ segment $2=3<4<$ head $=5<$ 6-16; thereafter body gradually tapering. Clypeolabral region sparsely setose, vertigial one showing only a few setae. Body surface generally smooth and shining (Fig. 24), only metazonae below paraterga usually faintly rugulose (Fig. 25A). Tergal setae rather long, ca 1/4 as long as metatergum, pattern at least as $2+2$ in a transverse pre-sulcus row, usually abraded (Fig. 25A). Transverse metatergal sulci only sometimes, and then at most barely, visible, incomplete (Fig. 25A). Parater- 


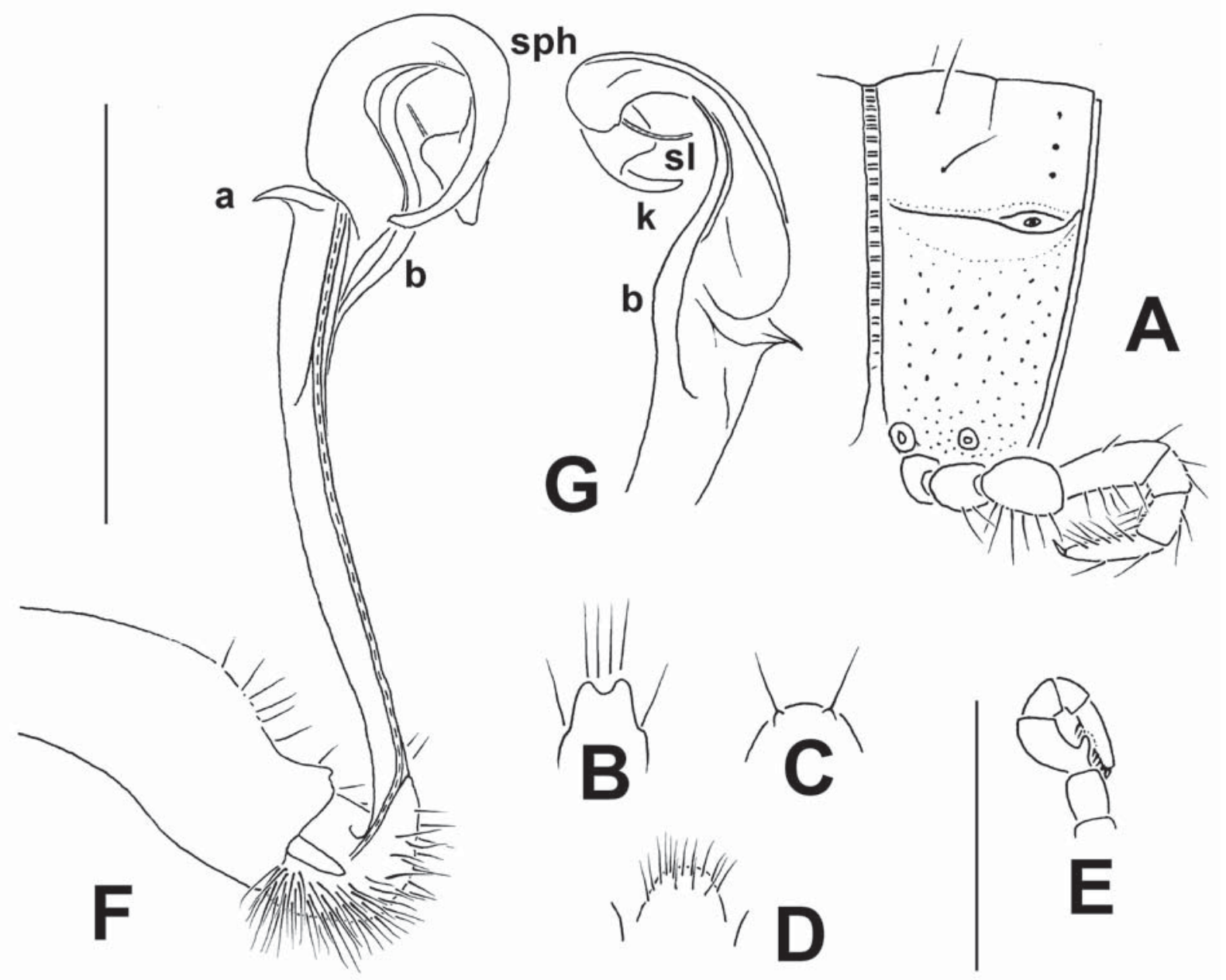

Fig. 23. Beronodesmus sinuatospinus sp.n., O $\mathrm{O}^{7}$ holotype. A - segment 10, lateral view; B - epiproct, dorsal view; C - hypoproct, ventral view; D - sternal lobe between coxae 4, ventral view; E - leg 1, lateral view; F \& G - left gonopod, mesal and lateral views, respectively. Scale bar: 1.0 (A-E) \& $0.5 \mathrm{~mm}(\mathrm{~F}, \mathrm{G})$.

Рис. 23. Beronodesmus sinuatospinus sp.n., голотип О7. А - сегмент 10, сбоку; В - эпипрокт, сверху; С - гипопрокт, снизу; $\mathrm{D}$ - стернальная пластина между тазиками 4, сзади; Е - нога 1, сбоку; F и G - левый гонопод, соответственно изнутри и сбоку. Масштаб: $1,0(\mathrm{~A}-\mathrm{E})$ и 0,5 мм $(\mathrm{F}, \mathrm{G})$.

ga delimited by a sharp sulcus only dorsally (Figs 24A, C, D, 25A). Stricture dividing pro- and metazonae striolate (Figs 25A). Pleurosternal carinae small lobes rather poorly visible only in segment 2 (Fig. 24A), toothless, thereafter very thin ridges or lines traceable until about segment 7. Epiproct (Fig. 24D, 25B) more or less clearly emarginate at apex, subapical lateral papillae very small, well removed from tip. Hypoproct (Fig. 25C) roundly subtriangular, caudal 1+1 setae clearly separated, not borne on knobs, placed at caudal margin.

A single, roundly subtrapeziform, setose lobe between coxae 4 (Fig. 25D). Legs densely setose ventrally, in $\sigma^{7}$ somewhat incrassate, short and stout, ca 1.11.2 times as long as midbody height (Figs 24A, 25A), prefemora swollen laterally; in 9 slender and shorter, ca 0.9-1.0 times as long as midbody height; $\sigma^{7}$ femur 1 incrassate, with a small, but evident, rounded, setose adenostyle ventrally near base (Fig. 25E); tarsal and distotibial brushes present until a few last leg-pairs ( $\left.\sigma^{7}\right)$ (Fig. 24A, 25A).

Gonopods (Fig. 25F, G) rather simple, very clearly elongate and distally falcate; femorite relatively simple, untwisted, very long and slender, suberect, clearly enlarged distally, with a very short, rounded, dorsal lobule (a) lying immediately distal to a lobe-shaped, dorsal, distofemoral expansion and a long, slender, lancetiform, ventral procees b level to distofemoral expansion; solenophore (sph) only slightly shorter than femorite, set off from femorite by a distinct cingulum, broadly rounded apically, at about midway with a strong mesal spine (c); sph about as long as a flagelliform solenomere (sl); seminal groove running entirely on mesal face of femorite, moving onto sl at base of $\mathbf{a}$.

REMARKS. The following key to Beronodesmus species can be proposed, based on $O^{T}$ characters. 

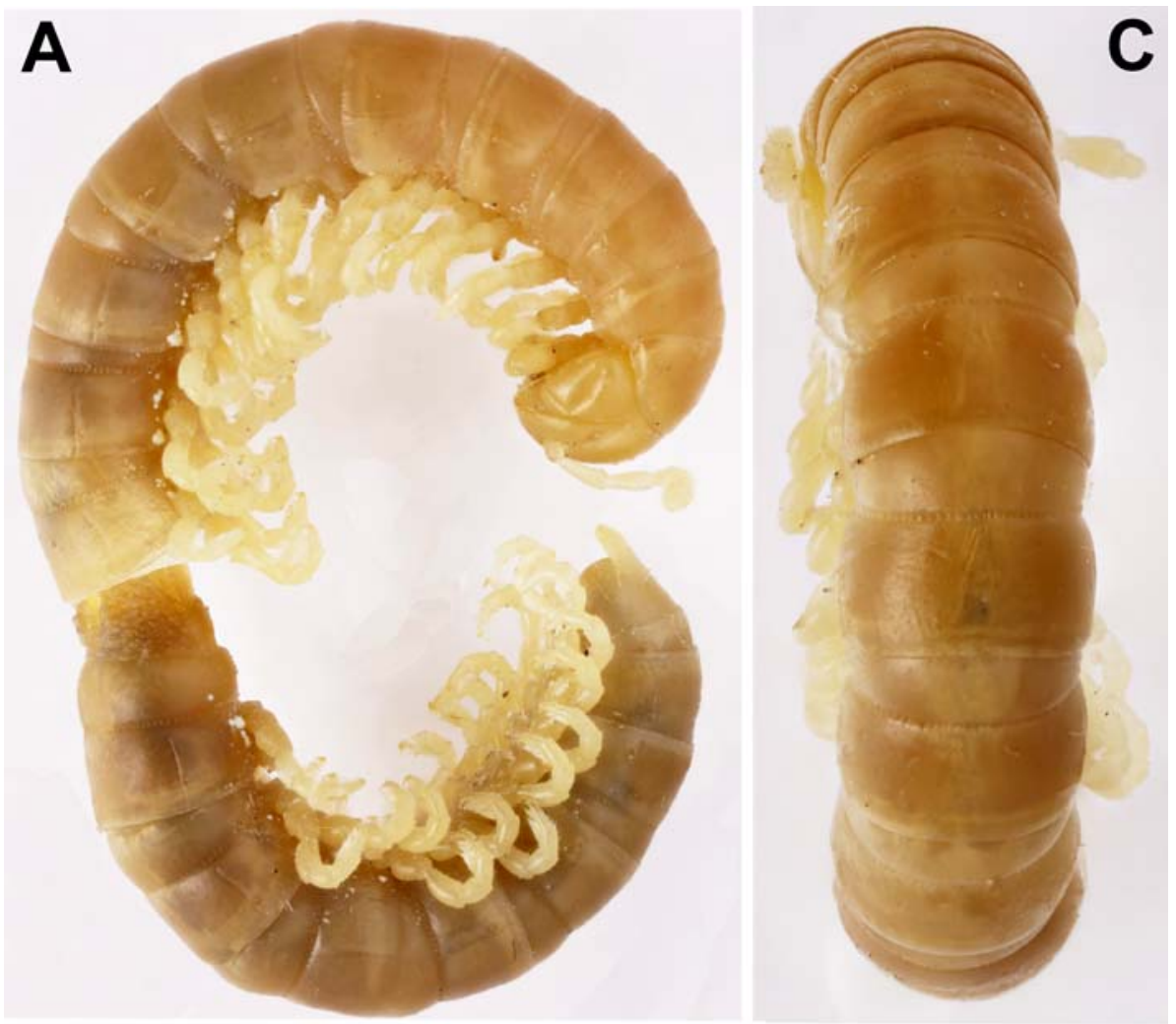

Fig. 24. Beronodesmus distospinosus sp.n., $\mathrm{O}^{\top}$ holotype. A habitus, lateral view; $\mathrm{B}$ - anterior part of body, ventral view; $\mathrm{C}$ middle part of body, dorsal view; D - caudal part of body, dorsal view. Pictures by K. Makarov, taken not to scale.

Рис. 24. Beronodesmus distospinosus sp.n., голотип $0^{7}$. А общий вид, сбоку; В - передняя часть тела, снизу; С среднетуловищные сегменты, сверху; D - задняя часть тела, сверху. Фотографии К. Макарова, без масштаба.
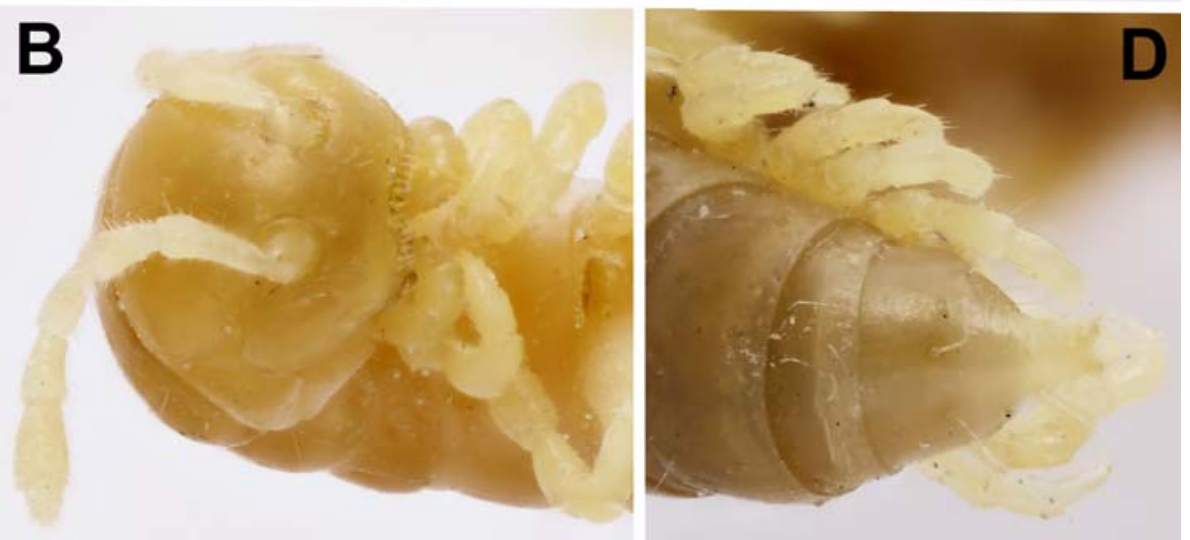

1(2) Solenophore (sph) with a remarkably long, strong, caudomesal spine $\mathbf{c}$ about midway (Fig. 25F, G) .......... B. distospinosus sp.n.

2(1) Solenophore (sph) without any spine about midway ........

3(4) Length ca $7 \mathrm{~mm}$, width of midbody segments ca $0.8 \mathrm{~mm}$ $\left(\sigma^{7}\right)$. Distofemoral process b of gonopod a large spine, whereas a a broad lobe (Fig. 11F, G) ... B. minutus sp.n.

4(3) $\sigma^{7}$ length $\geq 11 \mathrm{~mm}$, width $\geq 1.0 \mathrm{~mm}$. At least distofemoral process a of gonopod different in shape

5(6) Distofemoral spines $\mathbf{a}$ and $\mathbf{b}$ of gonopod rather small, subequal in shape and size ........................... B. pallidus

6(5) Distofemoral spines $\mathbf{a}$ and $\mathbf{b}$ of gonopod sharply different in shape and size

7(8) Gonopod distofemoral process b a short spine, whereas a a small, sometimes rudimentary lobule

8(7) Gonopod distofemoral process b a long to very lon spine, whereas a usually a rounded lobe
9(10) Distofemoral process b of gonopod a very short, but stout spine, whereas a an evident, rounded lobe (Fig. $21 \mathrm{~F}, \mathrm{G})$...................................... B. curtispinus sp.n.

10(9) Gonopod distofemoral process b a short, but slender spine, whereas a a rudimentary lobule (Figs $13 \mathrm{~F}, \mathrm{G}) \ldots$ B. gorkhalis sp.n.

11(12) Distofemoral process b sinuate, extremely long and slender, nearly as long as and tightly appressed to solenophore (sph), whereas a a small spine (Fig. 23F, G) .. B. sinuatospinus sp.n.

12(11) Distofemoral process b considerably shorter, suberect, whereas a lobe.

.. 13

13(14) Distofemoral process b a very strong, basally broad spine, whereas a a lobe (Figs $18 \mathrm{~F}, \mathrm{G}, 19)$

B. latispinosus sp.n.

14(13) Distofemoral process b a long and slender spine, whereas a a rounded lobule (Figs 15F, G, 16C)

B. longispinus sp.n. 


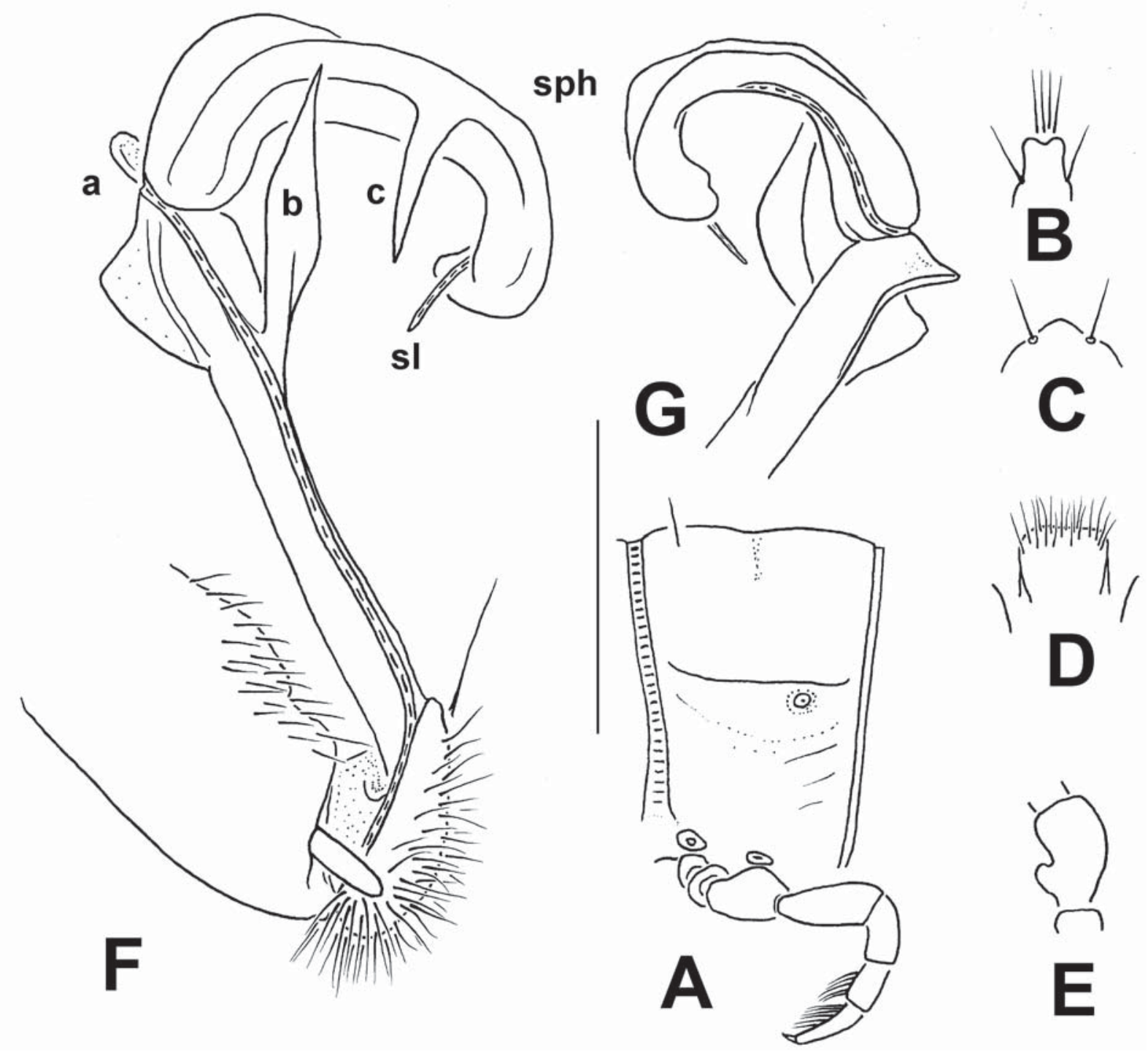

Fig. 25. Beronodesmus distospinosus sp.n., Ơ paratype from near Pass Deorali. A — segment 10, lateral view; B — epiproct, dorsal view; C - hypoproct, ventral view; D - sternal lobe between coxae 4, ventral view; E - femur 1, lateral view; F \& G - left gonopod, mesal and lateral views, respectively. Scale bar: 1.0 (A-E) \& $0.5 \mathrm{~mm}(\mathrm{~F}, \mathrm{G})$.

Рис. 25. Beronodesmus distospinosus sp.n., паратип О7 из окрестностей перевала Deorali. A — сегмент 10, сбоку; В — эпипрокт, сверху; C — гипопрокт, снизу; D - стернальная пластина между тазиками 4, сзади; E — бедро 1, сбоку; F и $\mathrm{G}$ - левый гонопод, соответственно изнутри и сбоку. Масштаб: $1,0(\mathrm{~A}-\mathrm{E})$ и 0,5 мм $(\mathrm{F}, \mathrm{G})$.

\section{Beronodesmoides gen.n.}

DIAGNOSIS. Very similar to Beronodesmus Golovatch, 2014, but differs in the gonopod femorite being devoid of considerable outgrowths distally before the apical sulcus/cingulum, coupled with either a long, regularly coiled, ribbon-shaped or short and lobeshaped, membranous solenophore supplied with at least one evident parabasal process and sometimes failing to support a similarly long, flagelliform, apically projecting, independent solenomere. Neither a gonopostfemoral part nor a solenophore geniculation, but an evident adenostyle on $\sigma^{7}$ femur 1 present.
NAME. To emphasize the close resemblance to Beronodesmus.

Type-species: Beronodesmoides anteriporus sp.n.

Other components: B. lobatus sp.n. and B. bifidus sp.n.

Beronodesmoides anteriporus sp.n.

Figs $26 \& 27$

HOLOTYPE OT (SMF), Nepal, Sankhua Sabha Distr., above Pahakhola, 2100-2300 m a.s.1., Quercus semecarpifolia-Rhododendron forest, 31.05-3.06.1988, leg. J. Martens \& W. Schawaller.

PARATYPES: $7 \sigma^{7} \sigma^{7}, 5$ 우 (SMF), $1 \sigma^{7}, 1$ ( 1 (ZMUM 02578 ), same data, together with holotype. 

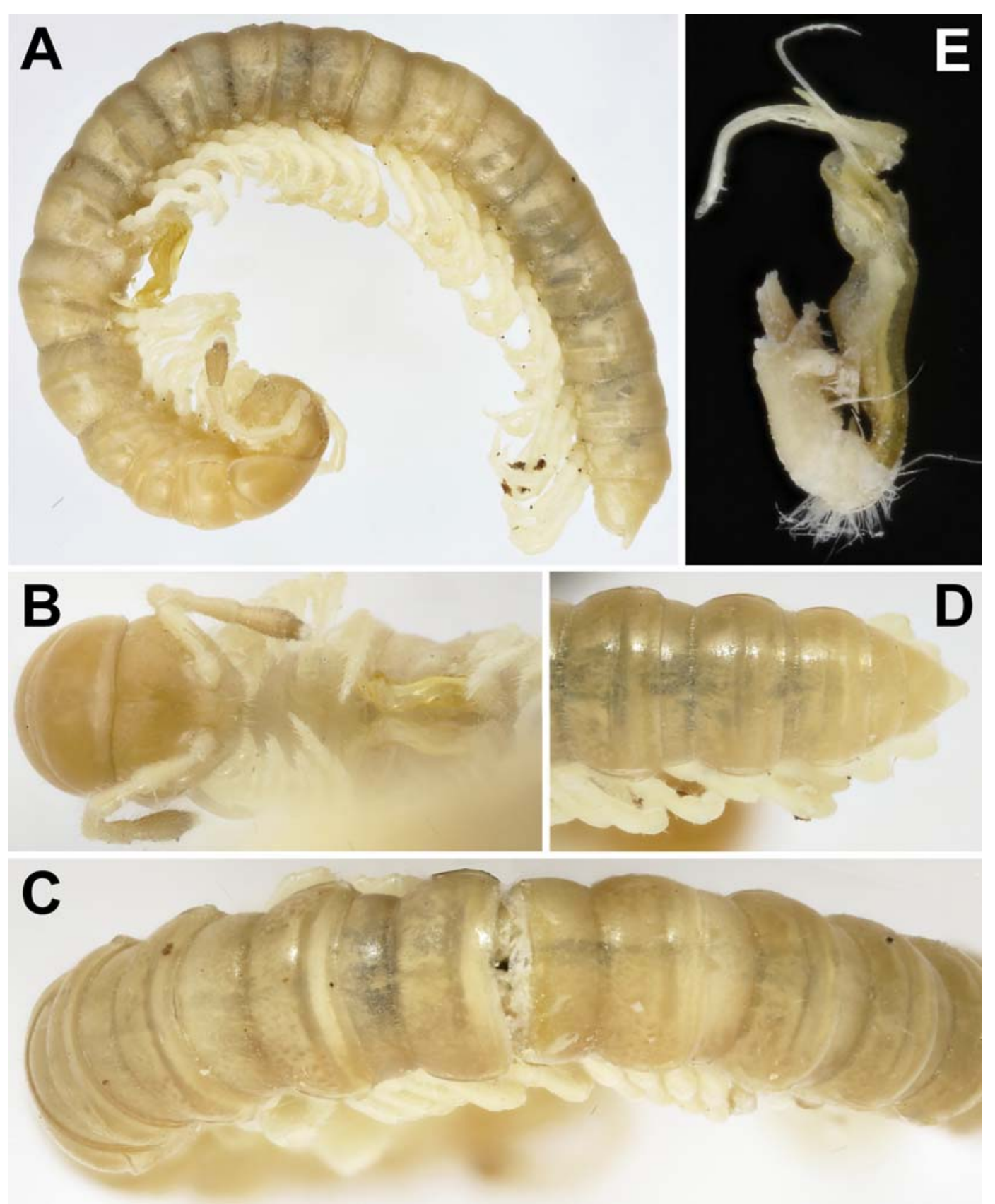

Fig. 26. Beronodesmoides anteriporus sp.n., O' paratype. A - habitus, lateral view; B - anterior part of body, ventral view; C middle part of body, dorsal view; D - caudal part of body, dorsal view; E - right gonopod, lateral view. Pictures by K. Makarov, taken not to scale.

Рис. 26. Beronodesmoides anteriporus sp.n., паратип о․ А - общий вид, сбоку; В - передняя часть тела, снизу; С среднетуловищные сегменты, сверху; D - задняя часть тела, сверху. Фотографии К. Макарова, без масштаба.

DIAGNOSIS. Differs from congeners by the ozopores on midbody segments shifted clearly forward compared to other congeners, coupled with the gonocoxite showing an evident, ventrobasal tubercle (k), and the main body of the solenophore (sph) being coiled not only around the independent, apically projecting solenomere (sl), but also around the parabasal process $\mathbf{s}$ (see also Key below).
NAME. To emphasize the ozopores on midbody segments shifted clearly forward compared to the conditions observed in both other congeners known to date; noun in apposition.

DESCRIPTION. Length ca 12-13 $\left(0^{7}\right)$ or 11-14 $\mathrm{mm}(+)$, width of midbody pro- and metazonae $0.8-1.0$ and $0.9-1.0 \mathrm{~mm}\left(\mathrm{O}^{7}\right)$, or $1.3-1.6$ and $1.4-1.7 \mathrm{~mm}$, respectively $(+)$. Holotype ca $13 \mathrm{~mm}$ long, 0.9 and 1.0 


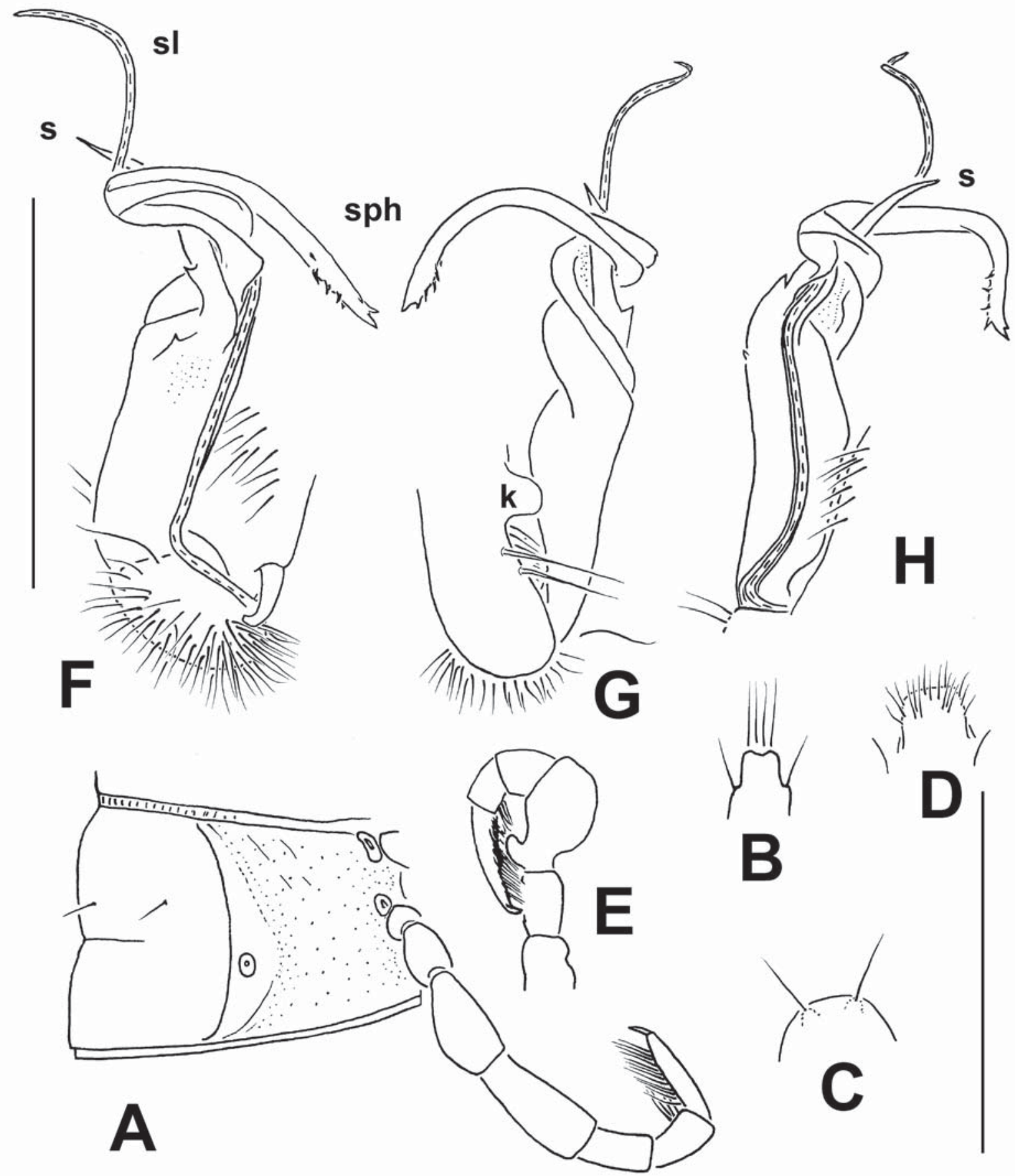

Fig. 27. Beronodesmoides anteriporus sp.n., $0^{\top 7}$ paratype. A - segment 10, lateral view; B - epiproct, dorsal view; C - hypoproct, ventral view; D - sternal lobe between coxae 4, ventral view; E - leg 1, lateral view; F-H - right gonopod, mesal, lateral and ventral views, respectively. Scale bars: $1.0 \mathrm{~mm}$

Рис. 27. Beronodesmoides anteriporus sp.n., паратип О'. А - сегмент 10, сбоку; В - эпипрокт, сверху; С - гипопрокт, снизу; $\mathrm{D}$ - стернальная пластина между тазиками 4, сзади; Е - нога 1, сбоку; F-H — правый гонопод, соответственно изнутри, сбоку и снизу. Масштаб: 1,0 мм.

mm wide on midbody pro- and metazonae, respectively. General coloration in alcohol from nearly pallid to light yellow or yellow-brown with grey tint, only distal parts of antennae (antennomeres 4-7, 5-7 or $6 \& 7$ ) increasingly brown, but tip whitish (Fig. 26).
All characters as in Beronodesmus minutus sp.n., except as follows.

In width, collum $<$ head $=$ segment $3=4<2<$ $5=15(16)$; thereafter body gradually tapering. Antennae rather poorly clavate and short, only slightly ex- 


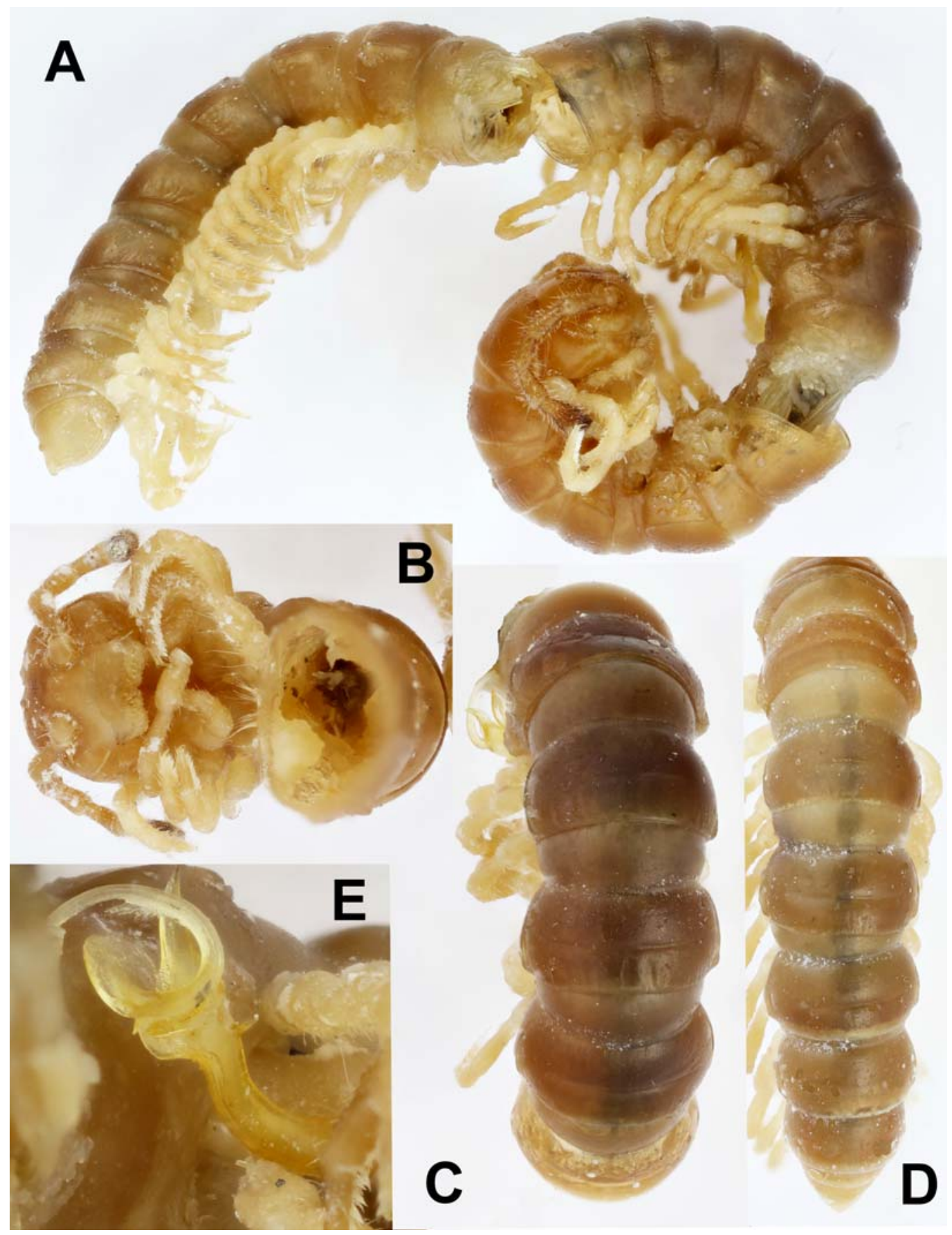

Fig. 28. Beronodesmoides lobatus sp.n., O $O^{7}$ paratype. A — habitus, lateral view; B — anterior part of body, ventral view; C - middle part of body, dorsal view; D - caudal part of body, dorsal view; E - right gonopod, ventral view. Pictures by K. Makarov, taken not to scale.

Рис. 28. Beronodesmoides lobatus sp.n., паратип О7. А - общий вид, сбоку; В - передняя часть тела, снизу; С - среднетуловищные сегменты, сверху; D — задняя часть тела, сверху; Е — правый гонопод, снизу. Фотографии К. Макарова, без масштаба.

tending back behind segment $2\left(\sigma^{\top}\right)$ or collum $(+)$ when stretched dorsally. Body surface generally smooth and shining (Fig. 26), only metazonae below paraterga usually faintly rugulose and microgranulate (Fig. 27A). Tergal setae rather short, ca $1 / 5-1 / 6$ as long as metatergum, pattern as $2+2$ setae in a transverse pre-sulcus row, usually abraded (Fig. 27A). Transverse metatergal sulci well visible on segments 5-17(18), far from reaching bases of paraterga (Figs 26A, C, D, 27A). Paraterga delimited by a sharp sulcus only dorsally, ventral sulcus if any much weaker, usually traceable only in caudal $1 / 3$ of $\sigma^{7}$ poriferous paraterga (Figs 


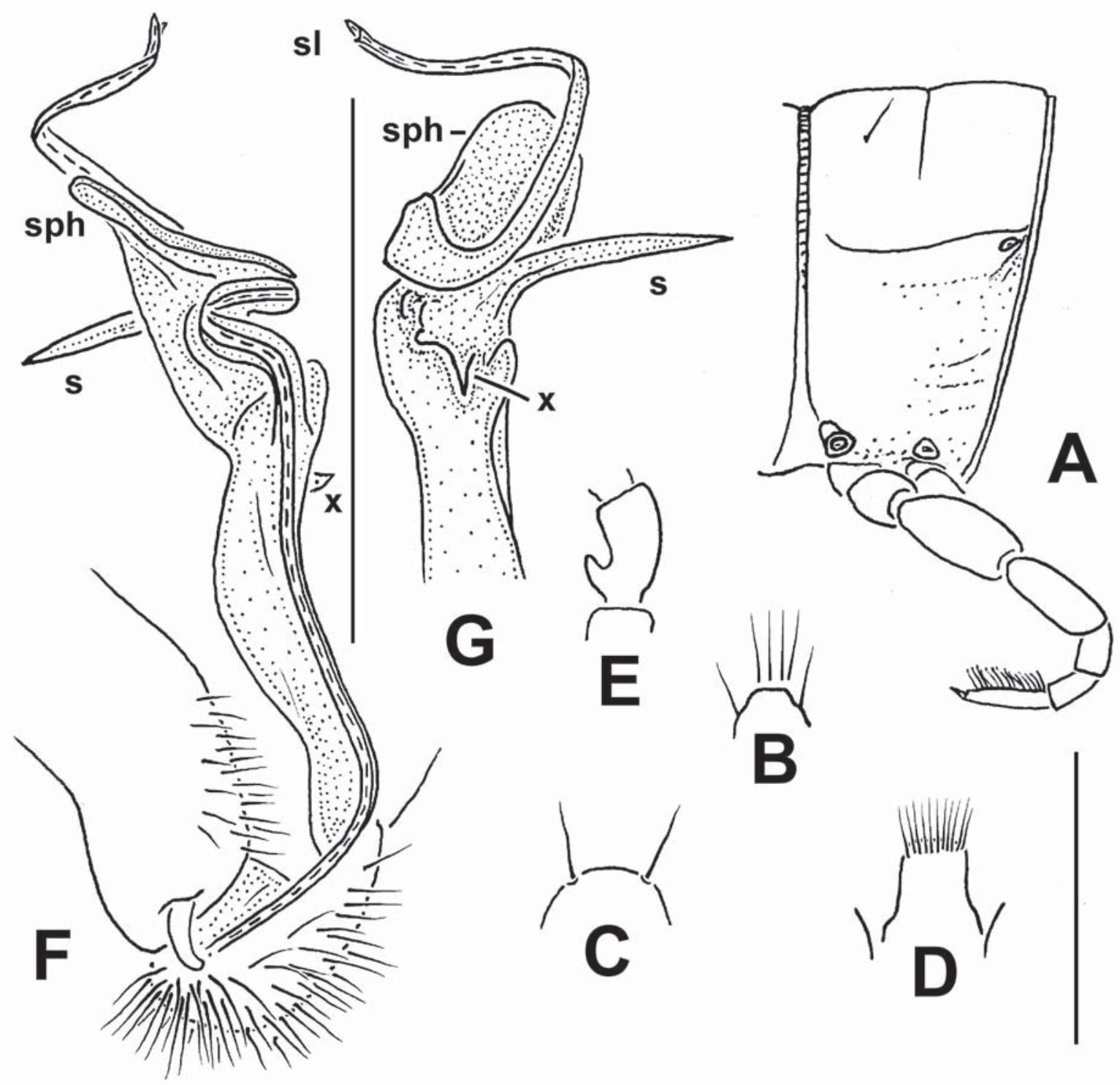

Fig. 29. Beronodesmoides lobatus sp.n., $\mathrm{O}^{7}$ holotype. A - segment 10, lateral view; B - epiproct, dorsal view; C - hypoproct, ventral view; D - sternal lobe between coxae 4, ventral view; E - femur 1, lateral view; F-H — right gonopod, mesal, lateral and ventral views, respectively. Scale bars: $1.0 \mathrm{~mm}$.

Pис. 29. Beronodesmoides lobatus sp.n., голотип О'. А - сегмент 10, сбоку; В - эпипрокт, сверху; С - гипопрокт, снизу; D стернальная пластина между тазиками 4, сзади; Е - бедро 1, сбоку; F-H - правый гонопод, соответственно изнутри, сбоку и снизу. Масштаб: 1,0 мм.

26A, 27A). Ozopores lateral, lying at bottom of a small pit at about 2/3 of paratergum's length (Fig. 27A). Stricture dividing pro- and metazonae finely striolate (Fig. 27A). Pleurosternal carinae missing. Epiproct (Figs 26D, 27B) more or less clearly emarginate at apex, subapical lateral papillae small, well removed from tip. Hypoproct (Fig. 26C) nearly semicircular, caudal $1+1$ setae clearly separated, not borne on knobs, placed at caudal margin.

A single, roundly subtrapeziform, setose lobe between $\sigma^{7}$ coxae 4 (Fig. 27D). Legs densely setose ventrally, in $\sigma^{T}$ somewhat incrassate, short and stout, ca 1.1-1.2 times as long as midbody height (Figs 26A,
$27 \mathrm{~A}$ ), prefemora nearly not swollen laterally; in + slender and shorter, ca 0.8-0.9 times as long as midbody height; $\sigma^{7}$ femur 1 especially strongly incrassate, with a small, but evident, rounded, setose adenostyle ventrally near base (Fig. 27E); distotibial brushes gradually thinning out towards midbody legs, tarsal brushed towards a few last leg-pairs ( $\left.\mathrm{O}^{7}\right)$ (Fig. 27A).

Gonopods (Figs 26A, E, 27F-H) rather complex; coxite elongate, subcylindrical, densely setose distoventrally, with a very distinct, rounded, ventrobasal tubercle (k); femorite relatively short and stout, somewhat twisted, not enlarged distally, suberect, with a minute distomesal spinicle basal to a distinct apical cingulum 


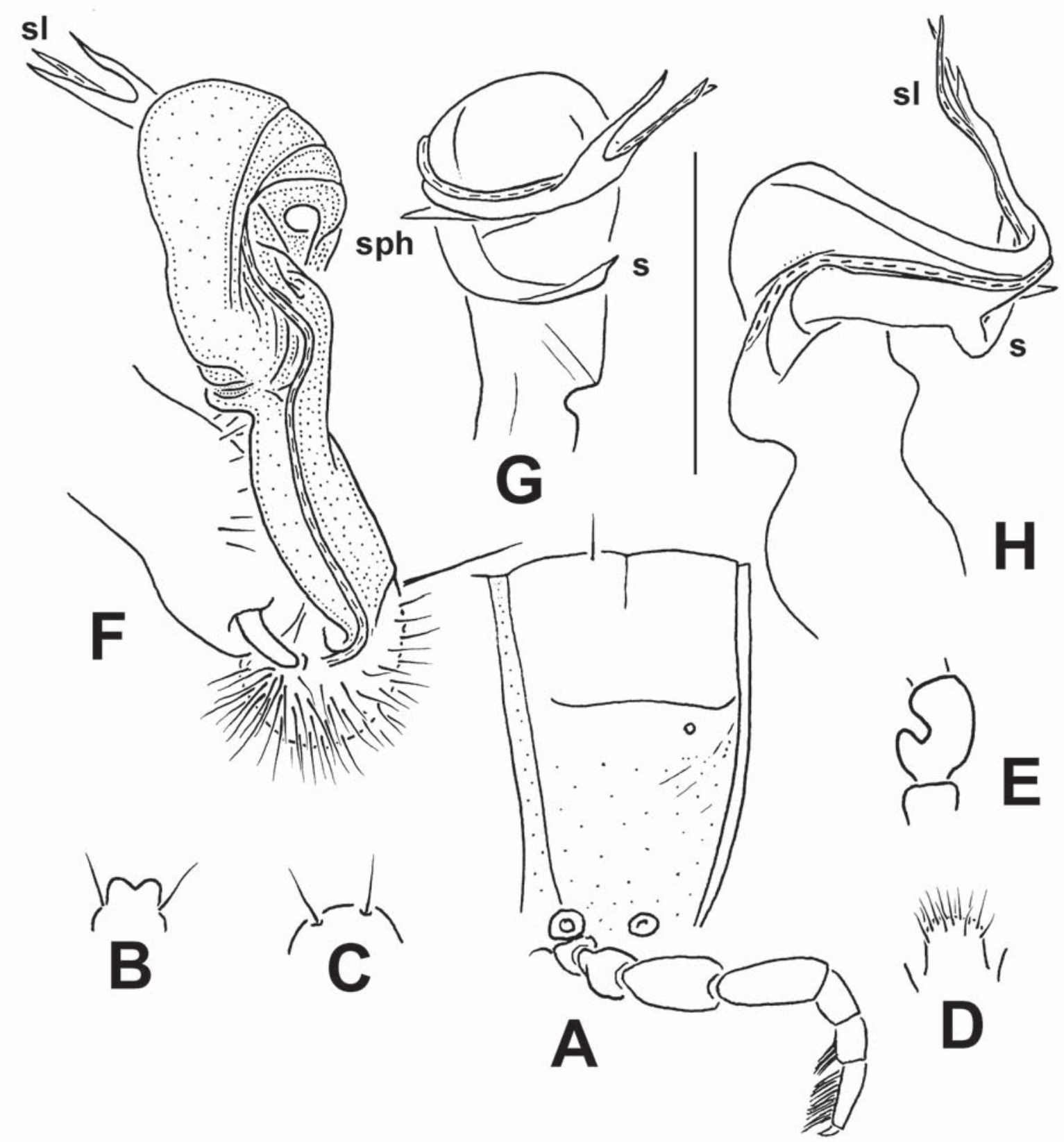

Fig. 30. Beronodesmoides bifidus sp.n., Ơ holotype. A - segment 10, lateral view; B - epiproct, dorsal view; C - hypoproct, ventral view; D - sternal lobe between coxae 4, ventral view; E - femur 1, lateral view; F-H - left gonopod, mesal, lateral and ventral views, respectively. Scale bars: $1.0(\mathrm{~A}-\mathrm{E}) \& 0.5 \mathrm{~mm}(\mathrm{~F}-\mathrm{H})$.

Рис. 30. Beronodesmoides bifidus sp.n., голотип О’. А - сегмент 10, сбоку; В - эпипрокт, сверху; С - гипопрокт, снизу; D стернальная пластина между тазиками 4, сзади; Е - бедро 1, сбоку; F-H - левый гонопод, соответственно изнутри, сбоку и снизу. Масштаб: $1,0(\mathrm{~A}-\mathrm{E})$ и 0,5 мм (F-H).

demarcating the base of a very long, coiled, membranous, slender, distally sparsely spinulate solenophore (sph); the latter at base carrying a long spine (s) fully surrounded by sph coil; s with a small spinicle near base; sph about as long as a flagelliform, independent, apically strongly projecting solenomere (sl); seminal groove running entirely on mesal face of femorite, moving onto sl at base of $\mathbf{s}$.

\section{Beronodesmoides lobatus sp.n.}

Figs $28 \& 29$

HOLOTYPE O' (SMF), Nepal, Sankhua Sabha Distr., from Thudam to Gabri Khola, 4000-4250 m a.s.l., dwarf Rhododendron thicket, 27.05.1988, leg. J. Martens \& W. Schawaller.

PARATYPE: $1 \sigma^{7}, 2$ 우 (SMF), same data, together with holotype.

DIAGNOSIS. Differs from congeners by the solenophore (sph) being largely represented by a conspicu- 


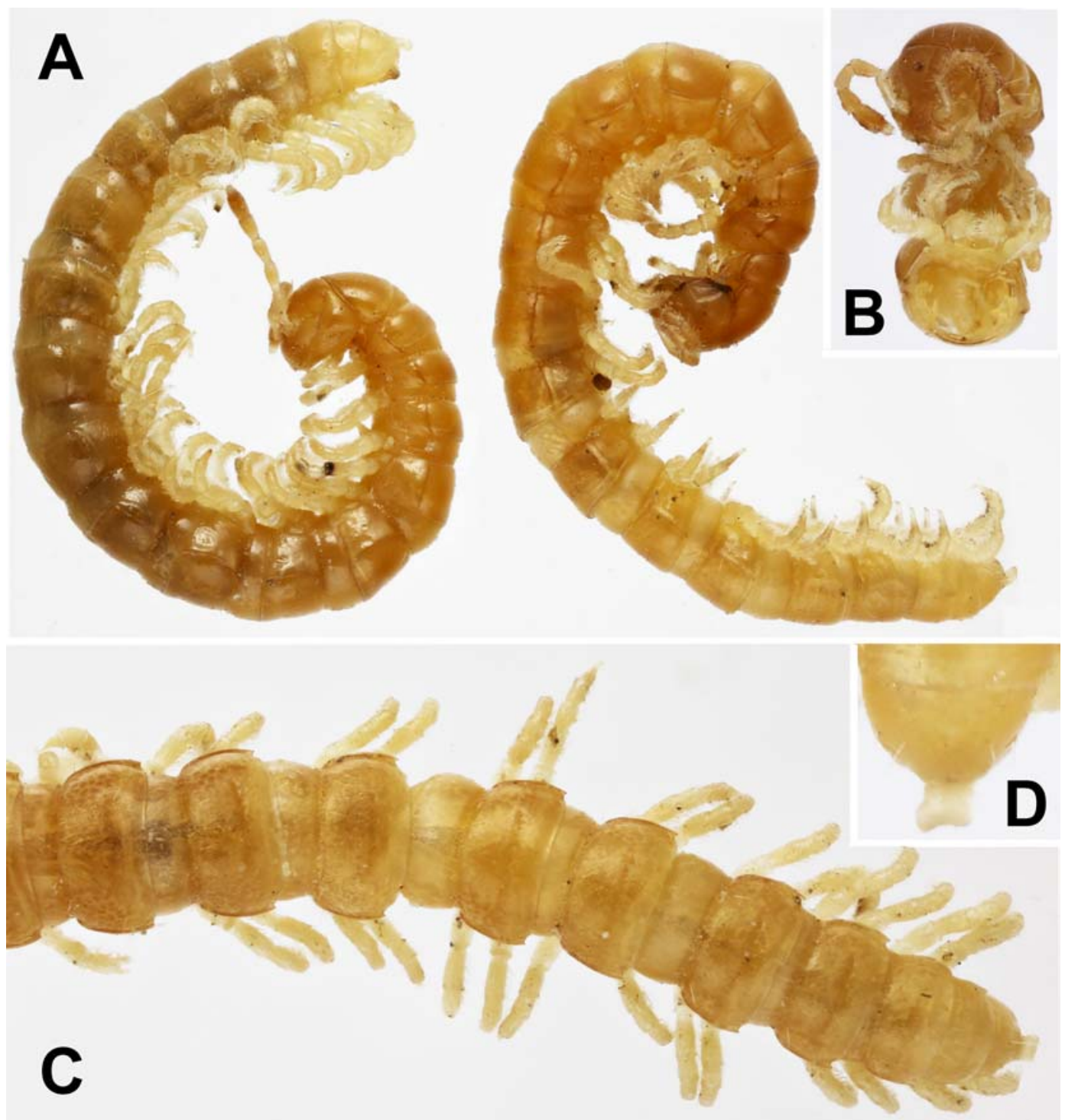

Fig. 31. Delarthrum curtisoma sp.n., $\mathrm{O}^{7}$ paratypes. A - habitus, lateral view; B - anterior part of body, ventral view; C - caudal half of body, dorsal view; D - telson, dorsal view. Pictures by K. Makarov, taken not to scale.

Рис. 31. Delarthrum curtisoma sp.n., паратипы $0^{\top} \bigcirc^{7}$. А - общий вид, сбоку; В - передняя часть тела, снизу; С - задняя половина тела, сверху; D — тельсон, сверху. Фотографии К. Макарова, без масштаба.

ous, large, mesal, round lobe carrying basally a smaller mesal tooth $(\mathbf{x})$ and a prominent lateral spine (s) (see also Key below).

NAME. To emphasize the mainly lobe-shaped solenophore; adjective.

DESCRIPTION. Length ca $18\left(\sigma^{7}\right)$ or $17 \mathrm{~mm}(+)$, width of midbody pro- and metazonae 1.6 and $1.8\left(O^{7}\right)$ or 1.8 and $2.0 \mathrm{~mm}$, respectively $(+)$. Coloration in alcohol from nearly pallid to light yellow-brown, anterior $1 / 3$ of body slightly infuscate (brownish), only distal part of antennomere 6 and entire $7^{\text {th }}$ dark brown, but tip whitish (Fig. 28).

All characters as in B. anteriporus sp.n., except as follows.

In width, head $=$ collum $=$ segment $3=4<2<$ $5=16$; thereafter body gradually tapering. Clypeolabral region sparsely setose, vertigial showing only a few setae. Transverse metatergal sulci well visible on segments 5-18, far from reaching bases of paraterga (Figs 28A, C, D, 29A). Paraterga delimited by a sharp sulcus only dorsally, ventral sulcus much weaker, usually traceable only in caudal $1 / 4$ of poriferous paraterga (Figs 28A, 29A). Ozopores lateral, lying at bottom of a small pit quite near paratergum's caudal corner (Fig. 29A). Epiproct (Figs 28D, 29B) truncate at apex, subapical lateral papillae very small, located close to tip. Hypoproct (Fig. 29C) semi-circular, caudal 1+1 setae clearly separated, not borne on knobs, placed at caudal margin.

A single, linguiform, high, apically subtruncate, setose lobe between $\sigma^{7}$ coxae 4 (Fig. 29D). Legs densely setose ventrally, in $\sigma^{7}$ somewhat incrassate, short and 


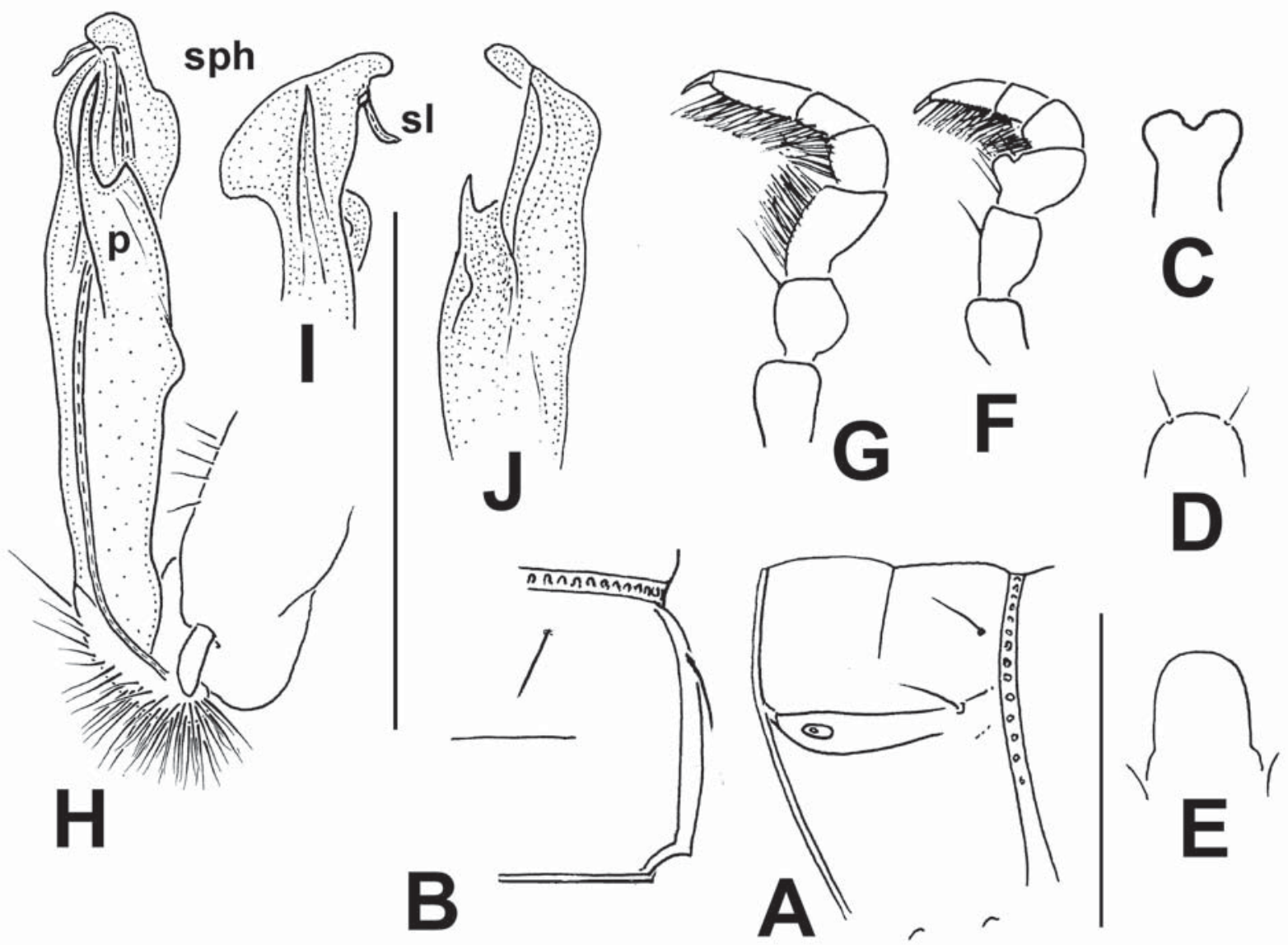

Fig. 32. Delarthrum curtisoma sp.n., O paratype. A \& B - right half of metazonite 10, lateral and dorsal views, respectively; C epiproct, dorsal view; D - hypoproct, ventral view; E - sternal lobe between coxae 4, ventral view; F - leg 1, lateral view; G - leg 7, lateral view; H-J — right gonopod, mesal, lateral and dorsal views, respectively. Scale bars: $0.5 \mathrm{~mm}$.

Рис. 32. Delarthrum curtisoma sp.n., паратип О7. А и В - правая половина метазонита 10, соответственно сбоку и сверху; С эпипрокт, сверху; D - гипопрокт, снизу; E - стернальная пластина между тазиками 4, снизу; F — нога 1, сбоку; G - нога 7, сбоку; Н-J - правый гонопод, соответственно изнутри, сбоку и сверху. Масштаб: 0,5 мм.

stout, ca 1.1-1.2 times as long as midbody height (Figs 28A, 29A), prefemora not swollen laterally; in 9 slender and shorter, ca 0.9-1.0 times as long as midbody height; $\sigma^{\top}$ femur 1 with a small, but evident, rounded, setose adenostyle ventrally near base (Fig. 29E); distotibial and tarsal brushes gradually thinning towards a few last leg-pairs $\left(\mathrm{O}^{7}\right)$ (Fig. 27A).

Gonopods (Figs 28E, 29F-H) rather simple; coxite elongate, subcylindrical, densely setose distoventrally; femorite nearly not enlarged distally, suberect, untwisted, apically with a distinct cingulum demarcating the base of a peculiar solenophore (sph); the latter not coiled, mostly a large, round, membranous, mesal lobe with a smaller mesal tooth $(\mathbf{x})$ and a prominent lateral spine (s) at base; solenomere (sl) long, flagelliform, independent, coiled, strongly projecting apically; seminal groove running entirely on mesal face of femorite, moving onto sl level to $\mathbf{s}$ base.

\section{Beronodesmoides bifidus sp.n.}

Fig. 30.

HOLOTYPE O ${ }^{\top}$ (SMF), Nepal, Dolakha Distr., Dadar Mt Range, SW of Mt Kalinchok, $3100 \mathrm{~m}$ a.s.l., pastures and degraded Abies densa, Betula utilis and Rhododendron forest, 19-23.04.1995, leg. J. Martens \& W. Schawaller.

DIAGNOSIS. Differs from congeners by the relatively short gonopod femorite, coupled with a long, coiled, membranous solenophore (sph) showing a bifid tip and a long process c located at about sph basal third, sph clearly supporting a long, flagelliform solenomere (sl) (see also Key below).

NAME. To emphasize a clearly bifid solenophore; adjective.

DESCRIPTION. Length ca $17 \mathrm{~mm}$, width of midbody pro- and metazonae 1.7 and $1.9 \mathrm{~mm}$, respectively $\left(\sigma^{7}\right)$. General coloration in alcohol uniformly light creamy, metazonae mostly light yellow-brown, only distal part of antennomere 6 and entire $7^{\text {th }}$ brown, but tip whitish.

All characters as in B. anteriporus sp.n., except as follows.

In width, head $=$ segment $3=4<$ collum $=2<5$ 15 ; thereafter body gradually tapering. Clypeolabral region sparsely setose, vertigial showing only a few setae. Body surface generally smooth and shining (Fig. 24), only metazonae below paraterga faintly rugulose and microgranulate (Fig. 30A). Tergal setae rather short, 


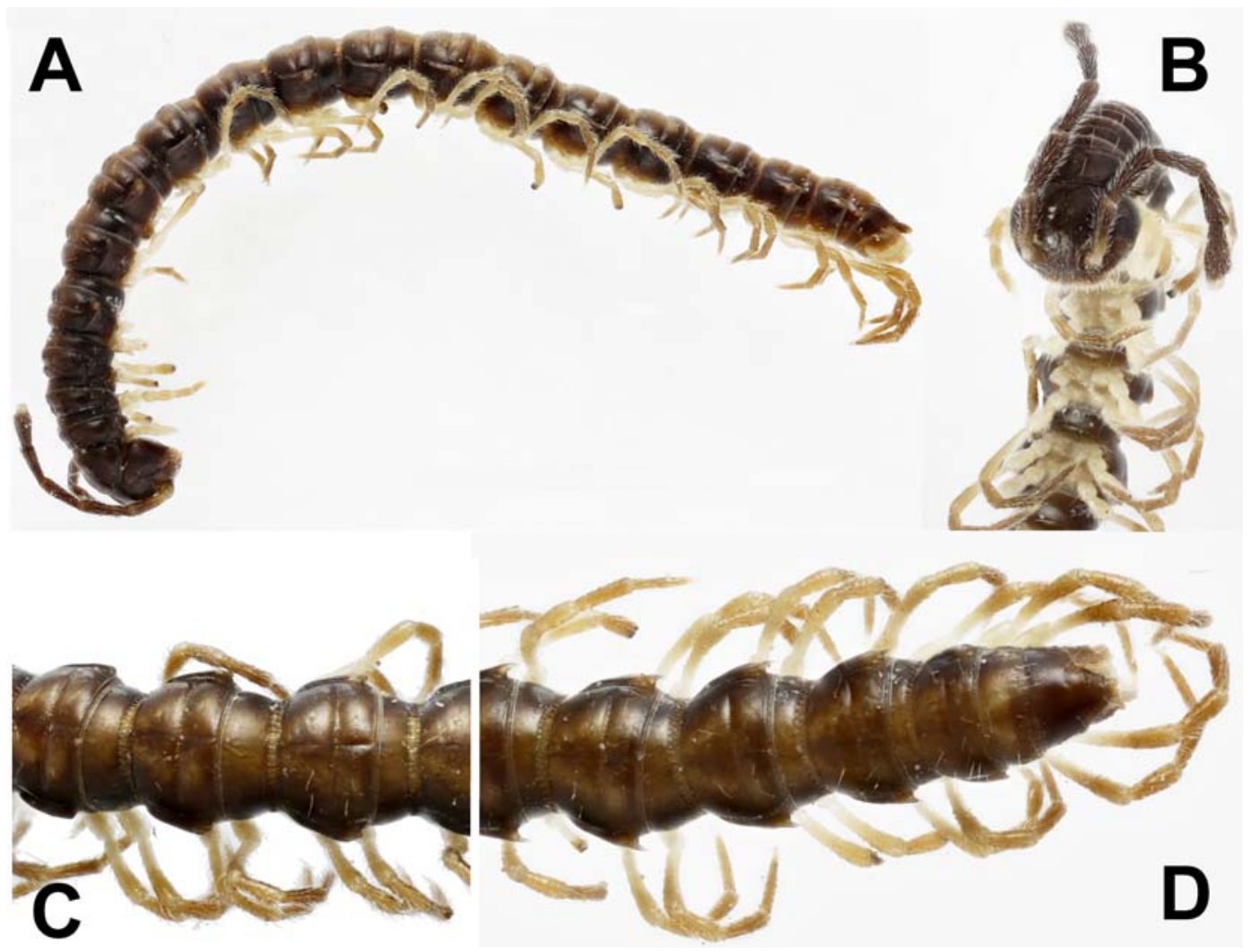

Fig. 33. Delarthrum gracile sp.n., $\bigcirc^{7}$ paratype. A — habitus, lateral view; B — anterior part of body, ventral view; C — caudal half of body, dorsal view; D - telson, dorsal view. Pictures by K. Makarov, taken not to scale.

Рис. 33. Delarthrum gracile sp.n., паратип О‥ А - общий вид, сбоку; В - передняя часть тела, снизу; С — задняя половина тела, сверхк; D — тельсон, сверху. Фотографии К. Макарова, без масштаба.

ca $1 / 5$ as long as metatergum, pattern as $2+2$ in a transverse pre-sulcus row, largely abraded (Fig. 30A). Transverse metatergal sulci poorly developed, incomplete, visible only in segments 6-17 (Fig. 30A). Paraterga delimited by a sharp sulcus only dorsally. Ozopores lying at ca 3/4 of paratergum's length. Stricture dividing pro- and metazonae nearly smooth (Figs 30A). Epiproct (Fig. 30B) clearly emarginate at apex, subapical lateral papillae small, rather well removed from tip. Hypoproct (Fig. 30C) semi-circular, caudal 1+1 setae clearly separated, not borne on knobs, placed near caudal margin.

A single, linguiform, apically rounded, setose lobe between coxae 4 (Fig. 30D). Legs densely setose ventrally, somewhat incrassate, short and stout, ca 1.1-1.2 times as long as midbody height, prefemora not swollen laterally $\left(\sigma^{7}\right)$ (Fig. 30A). $\sigma^{7}$ femur 1 with a small, but evident, rounded, setose adenostyle ventrally near base (Fig. 30E); tarsal and distotibial brushes present until several last leg-pairs ( $\left.O^{7}\right)$ (Fig. 30A).

Gonopods (Fig. 30F-H) rather complex; femorite relatively short and stout, suberect, nearly untwisted even distally, somewhat enlarged near apex; solenophore (sph) very long, massive, lamellar, strongly coiled, rather deeply bifid, supporting a similarly long, flagelliform solenomere (sl) all along, near basal third with a long, sharp, membranous process (s) and a short sharp tooth.

REMARKS. The following key can serve to separate all three species of Beronodesmoides gen.n.

1(2) Ozopores lying at about $1 / 3$ of paratergum's length in front of its caudal corner (Fig. 27A). Gonopod coxite with a peculiar ventrobasal tubercle (Fig. $27 \mathrm{~F}-\mathrm{H}$, k), solenophore (sph) long and slender, coiled around a long spiniform process (Fig. $27 \mathrm{~F}-\mathrm{H}, \mathbf{s}$ ) .....

B. anteriporus sp.n.

2(1) Ozopores lying far closer to caudal corner of paraterga. Gonopod coxite without a ventrobasal tubercle. Solenophore differently shaped, not coiled around s. ........... 3

3(4) Solenophore (sph) mainly a large round lobe not supporting a much longer, flagelliform, apical solenomere (sl) (Fig. 29F, G) B. lobatus sp.n.

4(3) Solenophore (sph) a long, coiled, membranous, apically bifid ribbon supporting a similarly long, flagelliform solenomere (sl) (Fig. 30F-H) B. bifidus sp.n.

\section{Delarthrum curtisoma sp.n.}

Figs $31 \& 32$

HOLOTYPE $0^{7}$ (SMF), Nepal, Sankhua Sabha Distr., Arun Valley, between Mure \& Hurure, 2050-2150 m a.s.l., mixed broadleaved forest, bushes near village, 8-17.06.1988, leg. J. Martens \& W. Schawaller. 


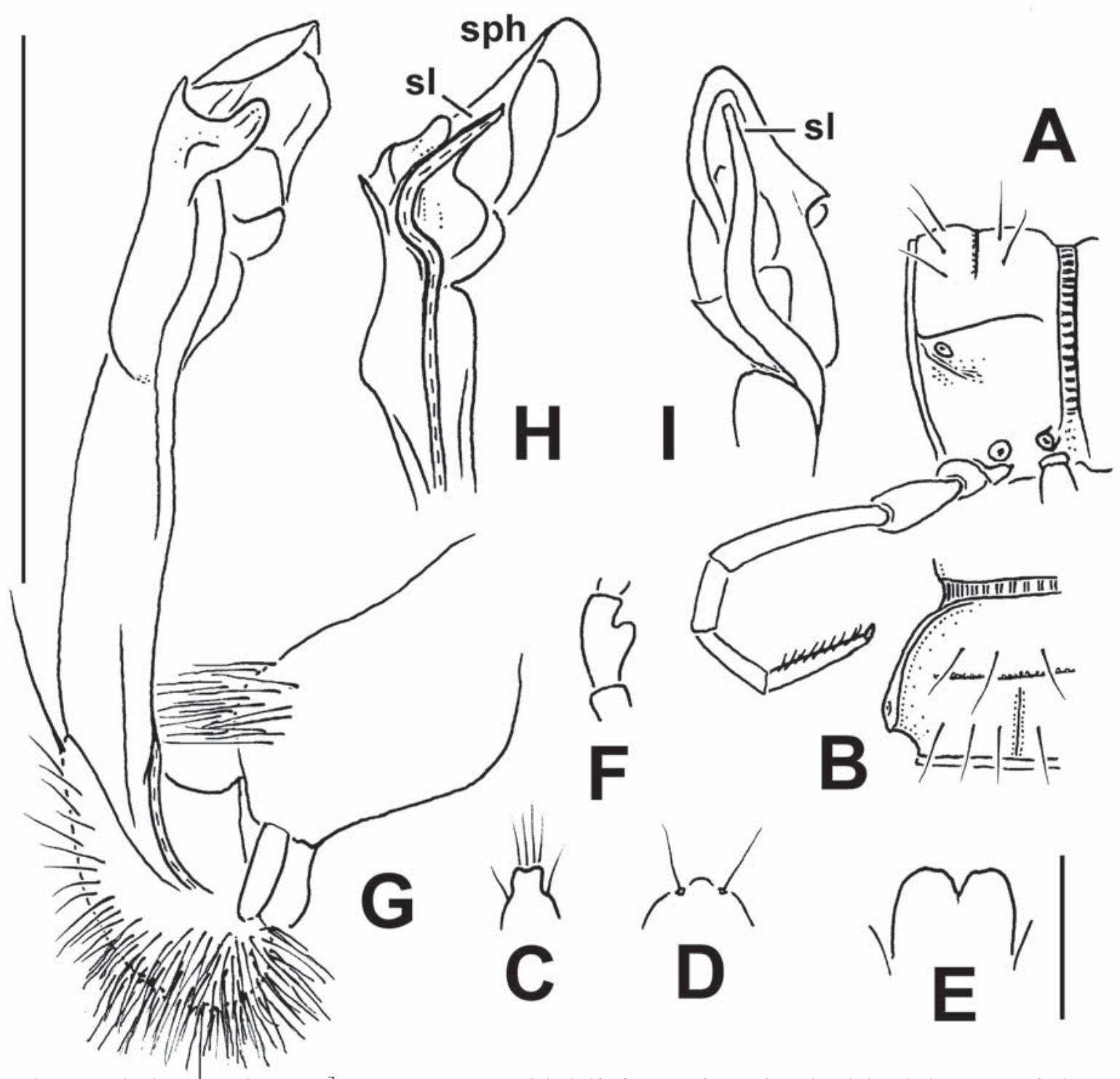

Fig. 34. Delarthrum gracile sp.n., $\sigma^{7}$ paratype. A \& B - right half of metazonite 10, lateral and dorsal views, respectively; C epiproct, dorsal view; D - hypoproct, ventral view; E - sternal lobe between coxae 4, ventral view; F - leg 1, lateral view; G - leg 7 , lateral view; H-J - right gonopod, mesal, lateral and dorsal views, respectively. Scale bars: $0.5 \mathrm{~mm}$.

Рис. 34. Delarthrum gracile sp.n., паратип О7. А и В - правая половина метазонита 10, соответственно сбоку и сверху; С эпипрокт, сверху; D - гипопрокт, снизу; E - стернальная пластина между тазиками 4, снизу; F — нога 1, сбоку; G - нога 7 , сбоку; Н-J - правый гонопод, соответственно изнутри, сбоку и сверху. Масштаб: 0,5 мм.

PARATYPES: 5 Oフ $0^{\top}, 19$ 우 (mostly fragmented) (SMF), 1 $\sigma^{7}, 1$ (ZMUM $\rho 2587$ ), same data, together with holotype.

DIAGNOSIS. Differs from congeners in showing only 19 body segments, coupled with a bone-shaped, distally broadened epiproct and a peculiar shape of the solenophore (sph).

NAME. To emphasize its shortened body counting only 19 segments; noun in apposition.

DESCRIPTION. Length ca $7.0\left(\sigma^{7}\right)$ or $8.0-9.0 \mathrm{~mm}$ $(+)$, width of midbody pro- and metazonae $0.7-0.8$ and 0.9-1.0 $\left(\mathrm{O}^{7}\right)$ or $0.9-1.0$ and $1.1-1.2 \mathrm{~mm}(+)$, respectively. Holotype ca 0.7 and $0.9 \mathrm{~mm}$ wide on pro- and metazonae, respectively. General coloration in alcohol from nearly pallid to light yellow-brown, usually ante- rior $1 / 3$ of body slightly more intensely coloured, only clypeus and labrum centrally, distal half of antennomere 6 and entire antennomere 7 often infuscate, light brown (Fig. 31).

Body with 19 segments (Fig. 31A). In width, collum $=$ segment $3=4<$ head $=2=5-15$; thereafter body gradually tapering. Clypeolabral region densely, vertigial region poorly, setose; epicranial suture distinct, starting above antennal sockets. Antennae poorly clavate, rather short, only slightly extending back behind segment $2\left(\sigma^{7}\right)$ or collum ( $(+)$ when stretched dorsally; antennomeres 2-6 subequal in length, much longer than $1^{\text {st }}$ and $7^{\text {th }}$. Dorsum very convex; paraterga lying at about midheight of body, poorly developed (Figs 31 A- 


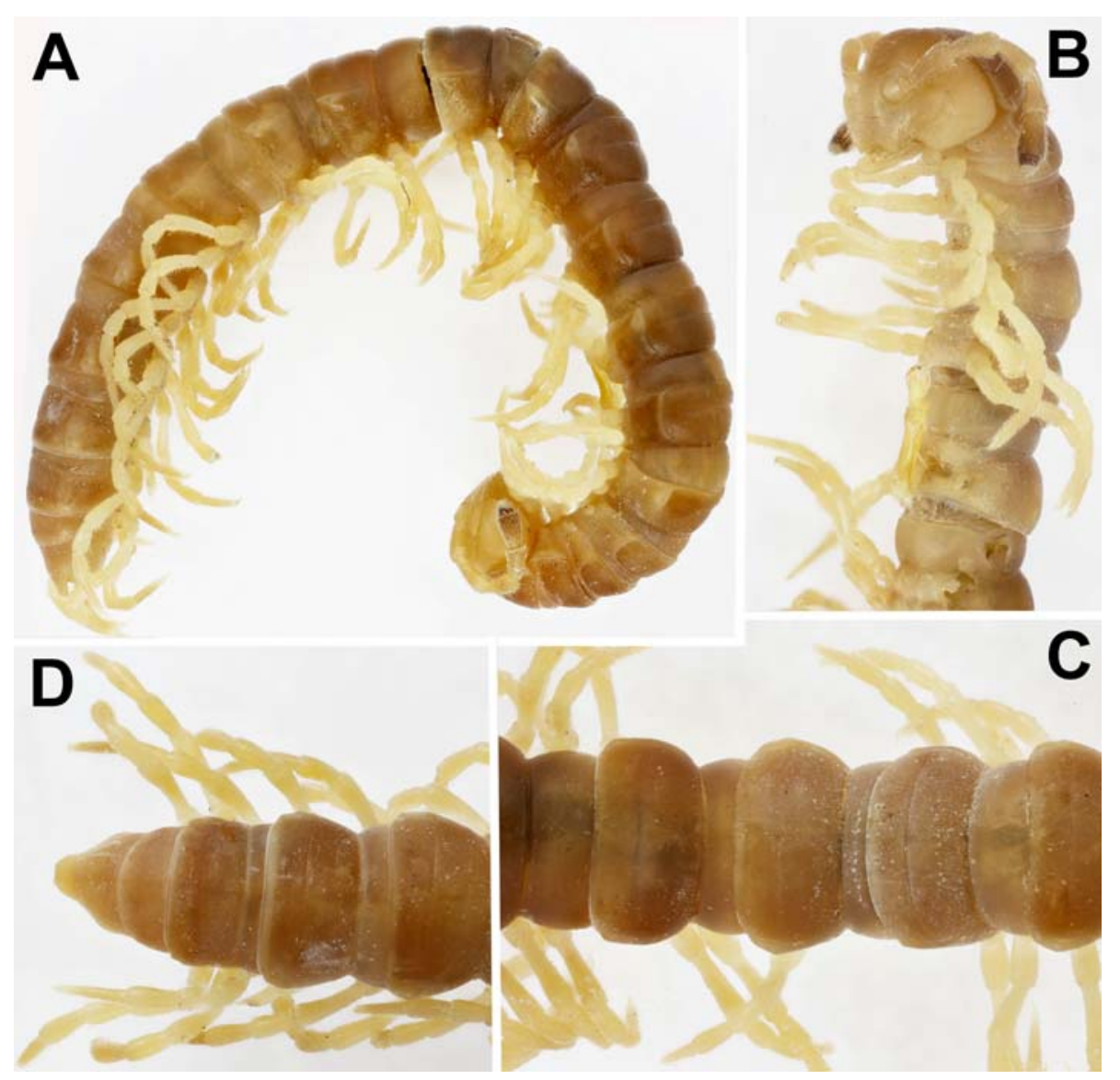

Fig. 35. Delarthrum planifemur sp.n., $0^{7}$ holotype. A - habitus, lateral view; B - anterior part of body, ventral view; C \& D middle and caudal parts of body, respectively, dorsal views. Pictures by K. Makarov, taken not to scale.

Рис. 35. Delarthrum planifemur sp.n., голотип OT. А - общий вид, сбоку; В - передняя часть тела, снизу; С и D соответственно средняя и задняя части тела, сверху. Фотографии К. Макарова, без масштаба.

C, 32A); a distinct, regularly declivous, ventrolateral, broadly rounded, margined lobe not produced behind rear tergal margin on collum (Fig. 31A); thereafter caudal corner increasingly dentiform and pointed, but not produced behind rear tergal margin, slightly drawn forward only in segment 2 (Figs 31A, 32B). Lateral calluses on postcollum paraterga smooth, narrow, only barely thicker in pore-bearing segments, thinner in poreless ones, subhorizontal, clearly delimited by a sulcus dorsally and, to a lesser degree, ventrally (Figs 31A, C, 32A, B). Ozopores lateral, each lying inside a shallow ovoid pit ca $1 / 4$ of callus length in front of caudal corner (Fig. 32A). Body surface smooth and shining throughout (Fig. 31). Axial line wanting. Transverse metatergal sulcus rather distinct, but thin, smooth at bottom, nearly reaching bases of paraterga 5-17, absent from $18^{\text {th }}$ (Figs $\left.31 \mathrm{C}, 32 \mathrm{~A}, \mathrm{~B}\right)$. Tergal setae long, ca $1 / 3$ as long as metatergum, pattern at least $1+1$ paramedian setae rather close behind stricture and one marginal seta in fore $1 / 4$ of callus (Fig. 32A, B). Stricture dividing pro- and metazonae narrow and rather shallow, beaded at bottom (Figs 31A, C, 32A, B). Pleurosternal carinae low arcuate ridges with a small caudal tooth in segments $2-4$, without teeth and increasingly poorly visi- ble until segment $10\left(O^{x}\right)$ or only small ridges without teeth in segments 2-4 (q). Epiproct conspicuously enlarged distally, bone-shaped (Figs 31A, C, D, 32C), subapical lateral papillae invisible. Hypoproct (Fig. 32D) semi-circular, caudal 1+1 setae clearly separated, not borne on knobs.

Sternites without modifications, rather densely setose; cross-impressions modest, but evident; a single, high, linguiform, apically rounded, forward directed, setose lobe between coxae 4 (Figs 31A, 32E). Legs rather short, in $\sigma^{7}$ clearly incrassate, with laterally bulged prefemora and very densely setose acropodites, ca 1.01.1 times as long as midbody height (Figs 31A, C, $32 \mathrm{G}$ ), versus only $0.8-0.9$ times in + . Adenostyle on $\mathrm{O}^{7}$ femur 1 distinct, setose (Fig. 32F).

Gonopods (Fig. 32H-J) rather short and stout, telopodite suberect; coxite short, subcylindrical, setose distoventrally; prefemoral (= densely setose) part even shorter, about $1 / 3$ the length of acropodite; femorite simple, on mesal face with a distinct distofemoral process (p) divided into a short tooth and a long spine, $\mathbf{p}$ lying at base of a long flagelliform solenomere (sl); a distofemoral sulcus delimiting a higher, laminar, membranous solenophore (sph) absent. 


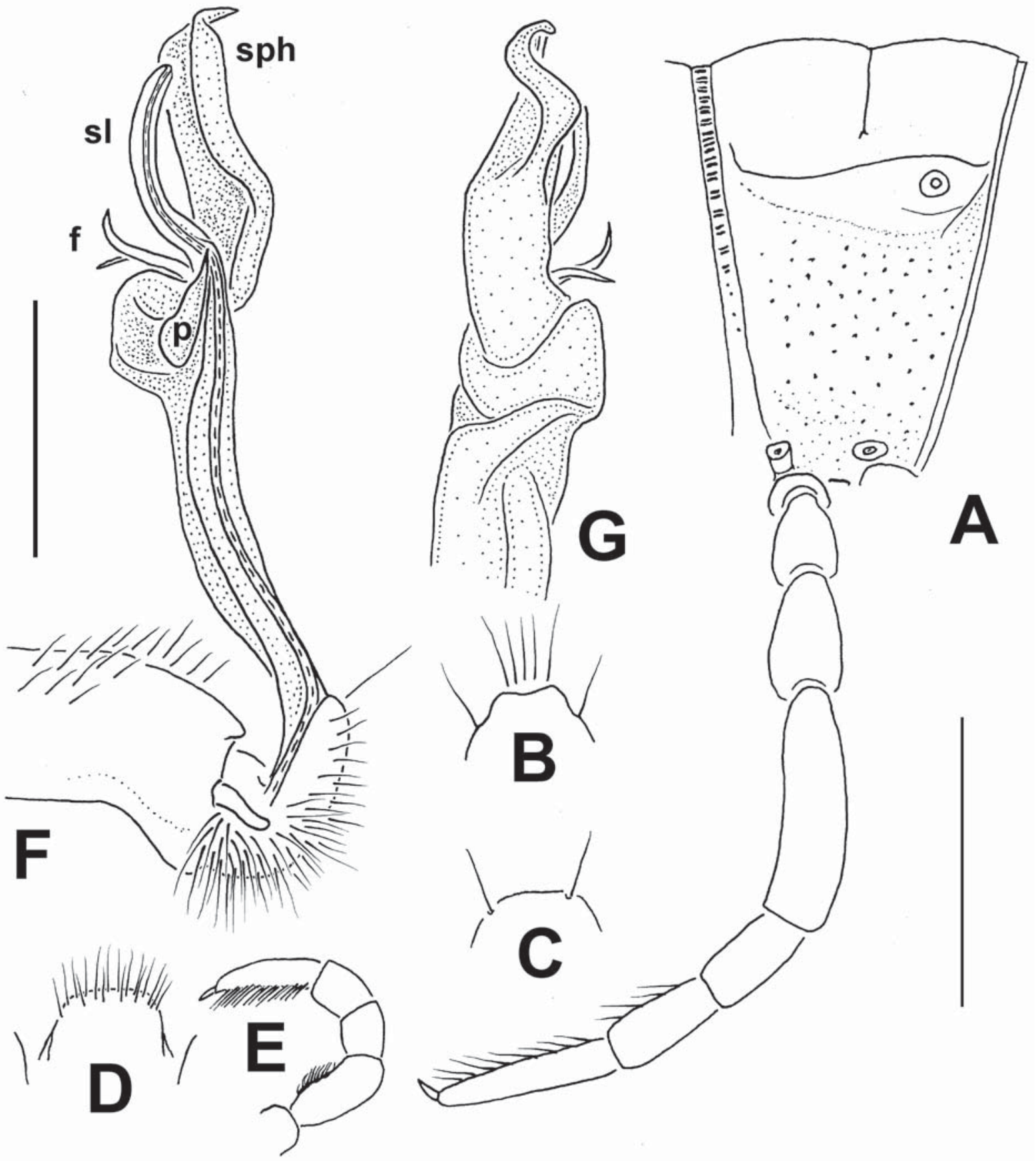

Fig. 36. Delarthrum planifemur sp.n., $\mathrm{O}^{7}$ holotype. A - left half of metazonite 10, lateral view; B - epiproct, dorsal view; C hypoproct, ventral view; D - sternal lobe between coxae 4, ventral view; E - leg 1, lateral view; F \& G — left gonopod, mesal and lateral views, respectively. Scale bars: 1.0 (A-E) \& $0.5 \mathrm{~mm}(\mathrm{~F}, \mathrm{G})$.

Рис. 36. Delarthrum planifemur sp.n., голотип ${ }^{7}$. А - левая половина метазонита 10, сбоку; В - эпипрокт, сверху; С гипопрокт, снизу; D - стернальная пластина между тазиками 4, снизу; Е - нога 1, сбоку; F и G - левый гонопод, соответственно изнутри и сбоку. Масштаб: 1,0 (A-E) и 0,5 мм $(\mathrm{F}, \mathrm{G})$.

REMARKS. The genus Delarthrum Attems, 1936 has recently been reviewed and shown to comprise 48 species ranging from Punjab, northern Pakistan in the west, through the Himalayas of Nepal and the adjacent parts of Tibet, China, to Assam, northeastern India in the east [Golovatch, 2014]. Due to the apparently espe- cially close resemblance of $D$. tenuitergale Golovatch, 2014, from Nepal, to Dasypharkis rugulosa (Carl, 1932), from Palni Hills, Tamil Nadu, southern India [Carl, 1932; Attems, 1936], in which a long, flagelliform, slightly sigmoid, fully erect solenomere is likewise only barely attached to a simple, lower, clearly 


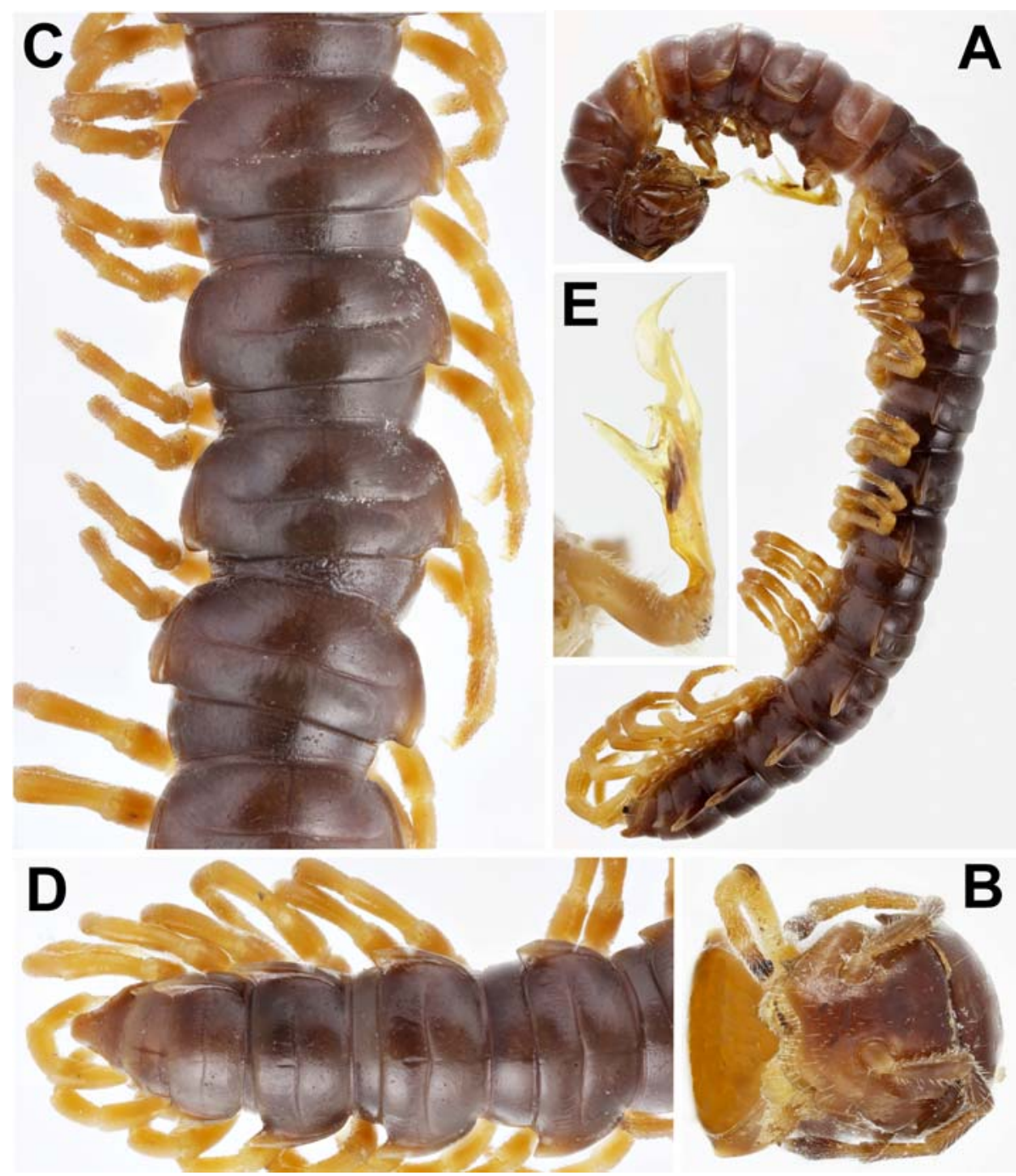

Fig. 37. Delarthrum densesetosum sp.n., $\mathrm{O}^{\text {T }}$ holotype. A - habitus, lateral view; B - anterior part of body, ventral view; C \& D middle and caudal parts of body, respectively, dorsal views; E — right gonopod, lateral view. Pictures by K. Makarov, taken not to scale.

Рис. 37. Delarthrum densesetosum sp.n., голотип о7. А - общий вид, сбоку; В - передняя часть тела, снизу; С и D соответственно средняя и задняя части тела, сверху; Е — правый гонопод, сбоку. Фотографии К. Макарова, без масштаба.

bilobed solenophore, the hitherto monobasic Dasypharkis Attems, 1936 is here considered as a new junior subjective synonym of Delarthrum, syn.n. This also results in the following new formal transfer: Delarthrum rugulosum (Carl, 1932), comb.n. ex Dasypharkis.

The generic diagnosis of Delarthrum as given by Golovatch [2014] thus needs the following minor modification to be made: body usually with 20 segments, only exceptionally 19 .

\section{Delarthrum gracile sp.n.}

Figs $33 \& 34$.

HOLOTYPE $\sigma^{7}$ (SMF), Nepal, Lalitpur Distr., Godawari, $27^{\circ} 36^{\prime} \mathrm{N}, 85^{\circ} 24^{\prime} \mathrm{E}$, foot of Mount Phulchoki, ca $1750 \mathrm{~m}$, secondary broadleaved forest, 09.08.1970, leg. J. Martens.

PARATYPE: 9 O $^{7} \mathrm{O}^{7}, 6$ 우 (SMF), 1 O $^{7}, 1$ ㅇ (ZMUM $\rho 2588$ ), same data, together with holotype.
DIAGNOSIS. Differs from congeners by the highly gracile body, coupled with long tergal setae arranged in two transverse rows (mostly $2+2$ and $3+3$ ), the presence of an axial line, caudally spinigerous paraterga, a bilobed sternal lamina between $\sigma^{7}$ coxae 4 , and a complex laminar solenophore (sph) set off from the gonopod femorite by a distinct cingulum.

NAME. To emphasize a highly gracile, submoniliform body; adjective.

DESCRIPTION. Length ca $12-14 \mathrm{~mm}$ in both sexes, maximum width (on head) 1.0-1.1 $\left(\sigma^{7}\right)$ or 1.2-1.3 $\mathrm{mm}(+)$, of midbody pro- and metazonae $0.8-0.9\left(\mathrm{O}^{7}\right)$ or $1.0-1.1 \mathrm{~mm}(+)$, respectively. Holotype ca $14 \mathrm{~mm}$ long and $1.0 \mathrm{~mm}$ wide (on head). General coloration in alcohol dark grey-brown, sometimes with slightly paler, also grey-brown middle parts of metaterga (except for fuscous axial line and transverse sulcus); legs pale, 
mostly whitish, increasingly brownish distad, up to light grey-brown; ozopore region usually grey-yellowish; venter pale to light brown; tips of antennae pallid (Fig. 33).

All characters as in D. curtisoma sp.n., except as follows.

Body highly gracile, submoniliform (Fig. 33). In width, collum $<<$ segment $3=4<2<5-16<$ head; body gradually tapering starting with segment 17 . Antennae poorly clavate, slender and long, slightly extending back behind segment $3\left(\sigma^{7}\right)$ or $2(+)$ when stretched dorsally; antennomeres $2-5$ subequal, a little longer than $6^{\text {th }}$, much longer than subequal $1^{\text {st }}$ and $7^{\text {th }}$. Paraterga on collum broadly rounded, caudal corner subrectangular (Fig. 33A); postcollum paraterga set at about half of body height, poorly developed, caudally likewise increasingly sharp teeth/spines not projecting behind rear margin (Figs 33, 34A, B). Lateral calluses on paraterga narrow, smooth, considerably thicker and slightly sinuate in front of ozopore on pore-bearing segments, thinner in poreless ones, very clearly delimited by a complete deep sulcus dorsally and, to a lesser degree, ventrally in caudal half only. Ozopores dorsolateral, each lying inside a shallow ovoid groove ca $1 / 4$ of callus length in front of caudal corner (Fig. 34A, B). Body surface smooth and shining, metaterga 4-17 with an axial line especially deep and clear in caudal halves (Figs 33C, 34B). Transverse metatergal sulcus very distinct, deep, mostly reaching bases of paraterga, punctate at bottom (Fig. 4B). Tergal setae long, usually ca $1 / 3$ the length of metatergum, on collum arranged in three transverse rows of $3+3,2+2$ and $3(2)+3(2)$, on following metaterga in two transverse rows, mostly $2+2$ and $3+3$ (Figs 33C, D, 34A, B), only starting with metatergum 16 or 17 caudal row with $4+4$ setae. Stricture dividing pro- and metazonae deep and rather broad, clearly ribbed at bottom (Fig. 34A, B). Pleurosternal carinae rather evident lobes only in segment 2, thin, arcuate, low, increasingly faint ridges or bulges traceable until segment $8\left(\sigma^{7}\right)$ or $3(+)$. Epiproct (Figs 33D, 34C) rather long, digitiform, slightly concave at apex, subapical lateral papillae small and well removed from tip. Hypoproct (Fig. 34D) nearly semi-circular, caudal $1+1$ setae clearly separated, not borne on knobs.

A single, but bilobed, setose lobe between $\sigma^{7}$ coxae 4 (Figs 34E). $\sigma^{7}$ legs very long and slender, ca 2.1-2.3 times as long as midbody height (Figs 33, 34A), versus 1.1-1.3 times in ${ }_{+}$; prefemora not swollen laterally, femora clearly longest; adenostyles on $\sigma^{7}$ femora 1 distinct, setose; $\sigma^{\top}$ tarsal brushes gradually thinning out towards legs of segment 9 or 10 (Fig. 34A).

Gonopods (Fig. 34G-I) rather complex, telopodite elongate and suberect; coxite medium-sized, subcylindrical, densely setose distoventrally; prefemoral (= densely setose) part short, nearly $1 / 3$ the length of femorite; the latter simple, slender, nearly not enlarged distad, showing a vague, dorsal, longitudinal impression to support the seminal groove, delimited by a light fold on each side, set off apically from solenophore (sph) by a distinct cingulum near base of a flagelliform, but relatively short solenomere (sl); sph laminar, membranous, broadly rounded at tip.

\section{Delarthrum planifemur sp.n.}

Figs $35 \& 36$.

HOLOTYPE $\sigma^{7}$ (SMF), Nepal, Kaski Distr., above Pothana, 2000 m a.s.1., 27-29.04.1995, leg. J. Martens \& W. Schawaller.

DIAGNOSIS. Differs from congeners by the lack of an adenostyle on $\sigma^{7}$ femur 1 , which is a rare trait in Delarthrum (e.g. D. rugulosum or D. beroni Golovatch, 2014), coupled with a peculiar conformation of the spermophore (sph) which shows a special, bifurcate, snake tongue-shaped flagelloid (f) at the base of a rather short, ribbon-shaped solenomere (sl).

NAME. To emphasize the absence of an adenostyle on $\sigma^{7}$ femur 1 ; noun in apposition.

DESCRIPTION. Length ca $24 \mathrm{~mm}$, width of midbody pro- and metazonae 1.8 and $2.0 \mathrm{~mm}$, respectively. Coloration in alcohol uniformly light brown, only antennomere 6 brown distally, $7^{\text {th }}$ entirely dark brown while legs light yellowish (Fig. 35).

Body submoniliform. In width, head $<$ collum $=$ segment $3=4<2<5-16$; thereafter body gradually tapering. Clypeolabral region densely, vertigial region poorly, setose; epicranial suture a thin line. Antennae rather poorly clavate and short, only slightly extending back behind segment 2 when stretched dorsally $\left(\sigma^{7}\right)$; in length, antennomere $2=6>3=4=6>1=7$. Dorsum strongly and regularly convex, postcollum paraterga very small, mostly represented by a lateral callus delimited by a deep and complete dorsal sulcus and, in caudal $1 / 3$ only, by a weaker ventral sulcus; paraterga lying at about upper body $1 / 3$, never drawn behind rear tergal margin (Figs 35, 36A). Calluses slightly sinuate and thicker in ozopore region. Ozopores lying inside a shallow ovoid pit ca $1 / 4$ of callus length in front of caudal corner (Fig. 36A). Body surface generally smooth and rather dull, only metazonae below paraterga finely microgranulate (Fig. 36A). Axial line missing. Transverse metatergal sulci on segments 5-18, complete, reaching bases of paraterga. Tergal setae nearly fully abraded, medium-sized, a few retained only on collum; pattern untraceable. Stricture dividing pro- and metazonae rather deep and narrow, clearly ribbed at bottom dorsally and dorsolaterally (Fig. 36A). Pleurosternal carinae small lobes clearly visible only in segment 2, less evident in segment 3, missing thereafter. Epiproct (Figs 35A, D, 36B) rather long, unusually broadly subtruncate and faintly concave at apex, subapical lateral papillae small and well removed from tip. Hypoproct (Fig. 36C) rather semi-circular, caudal 1+1 setae clearly separated, not borne on knobs, placed at caudal margin.

Sternites without modifications, densely setose; cross-impressions weak; a single, roundly subtrapeziform, setose lobe between coxae 4 (Fig. 36D). Legs rather densely setose ventrally, long and slender, ca $1.4-1.5$ times as long as midbody height $\left({ }^{7}\right)$ (Figs 35, 

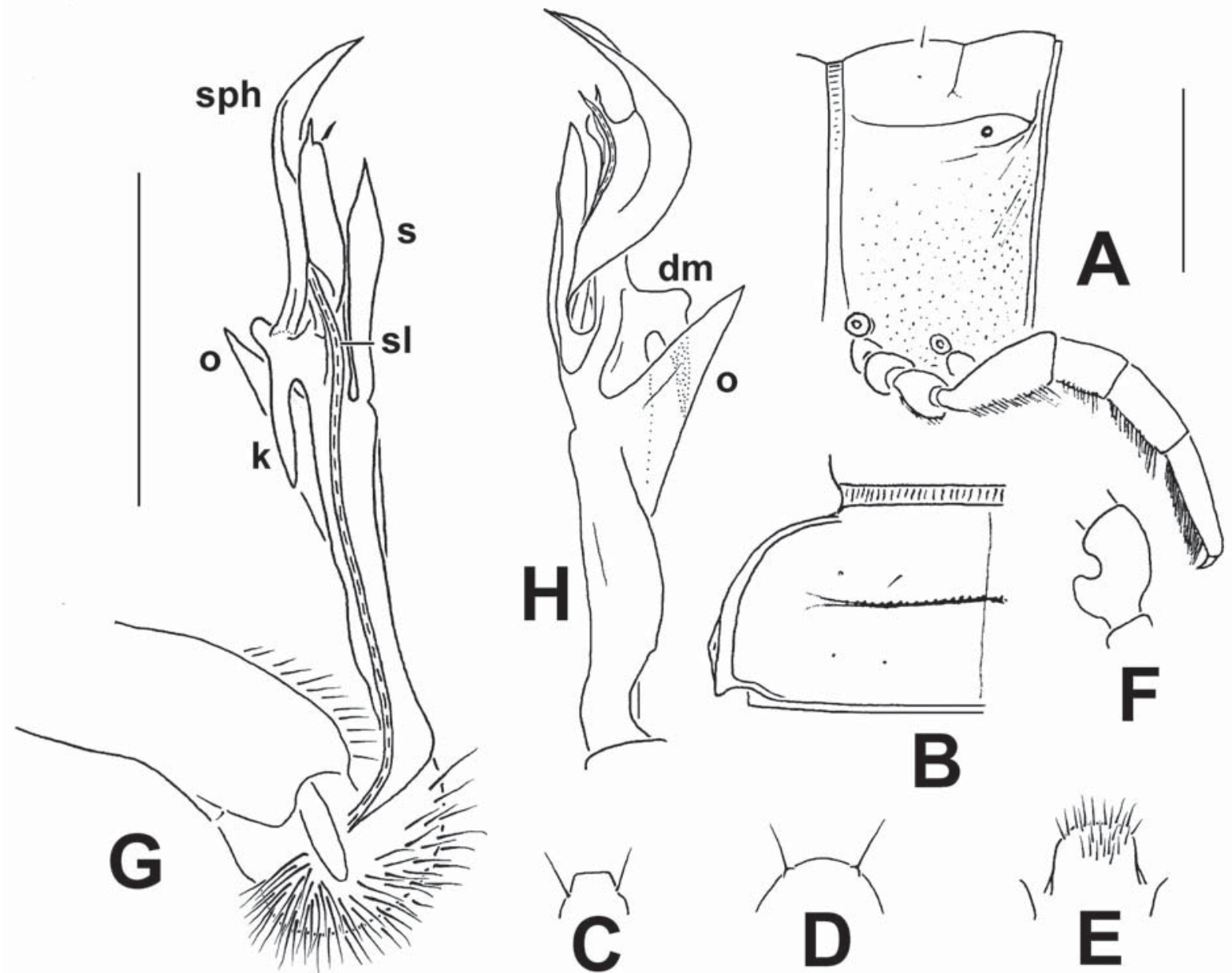

Fig. 38. Delarthrum densesetosum sp.n., O' holotype. A \& B - left half of metazonite 10, lateral and dorsal views, respectively; C epiproct, dorsal view; D — hypoproct, ventral view; E — sternal lobe between coxae 4, ventral view; F — femur 1, lateral view; G \& H left gonopod, mesal and lateral dorsal views, respectively. Scale bars: $1.0 \mathrm{~mm}$.

Рис. 38. Delarthrum densesetosum sp.n., голотип О’. А и В - левая половина метазонита 10, соответственно сбоку и сверху; С эпипрокт, сверху; D — гипопрокт, снизу; E — стернальная пластина между тазиками 4, снизу; F — бедро 1, сбоку; G и H — левый гонопод, соответственно изнутри и сбоку. Масштаб: 1,0 мм.

36A), prefemora not swollen laterally, legs 1 without an adenostyle (Fig. 36E); tarsal brushes gradually thinning out towards legs of segment $9\left(\sigma^{7}\right)$.

Gonopods (Figs 36F, G) rather complex, elongate and suberect; coxite long, subcylindrical, setose distoventrally; prefemoral (= densely setose) part, short, about half the length of femorite; the latter simple, untwisted, suberect, clearly flattened dorsoventrally and enlarged distad before a distinct cingulum setting off a phylloid solenophore ( $\mathbf{s p h})$; solenomere (sl) shorter than sph, ribbon-shaped, near base with a small, but evident, sharp, mesal, distofemoral process (p) and a small, but conspicuous, bifurcate, snake tongue-shaped, even longer flagelloid (f).

\section{Delarthrum densesetosum sp.n.}

Figs $37 \& 38$.

HOLOTYPE $0^{7}$ (SMF), Nepal, Myagdi Distr., Myagdi Khola, Dobang, 2400 m a.s.1., 25.05.1995, leg. J. Martens \& W. Schawaller.

PARATYPE: 1 (SMF), same data, together with holotype.
DIAGNOSIS. Among congeners, D. densesetosum sp.n. seems to be particularly similar to D. fechteri (Golovatch, 1990), also from central Nepal [Golovatch, 1990]. Both share medium-sized paraterga on a relatively large ( $>25 \mathrm{~mm}$ long) and dark brown body, long antennae and, especially, the shape of the gonopod telopodite, i.e. a large, subtriangular, lateral, distofemoral process $\mathbf{0}$, a long, ventral, distofemoral process $\mathbf{s}$, a high and subfalcate solenophore (sph) which is much higher than a slender flagelliform solenomere (sl). However, the new species differs clearly in the absence of an adenostyle on $\sigma^{7}$ femur 2 and of a basal prefemoral outgrowth on the lateral side of the gonopod prefemorite, whereas $\mathbf{s}$ is erect and not twisted distolaterad. The presence of a distomedial outgrowth $\mathbf{d m}$ with a strong caudally directed process $\mathbf{k}$ makes the new species especially distinct.

NAME. To emphasize the especially abundant setae ventrally on $\sigma^{7}$ telopodites; adjective.

DESCRIPTION. Length ca 26-27 mm $\left(\sigma^{7},+9\right)$, width of midbody pro- and metazonae 2.0 and $2.7(+)$ or 2.2 
and $2.9 \mathrm{~mm}\left(\sigma^{7}\right)$, respectively. Coloration in alcohol uniformly light yellow-brown $\left(O^{7}\right)$ or dark-brown $(+)$, only antennomeres 1-5 and legs light yellowish or light brown, growing infuscate (brown) distad, tip of antennae whitish (Fig. 37).

Body submoniliform. In width, collum $<$ head $=$ segment $3=4<2<5-15$; thereafter body gradually tapering. Clypeolabral region densely, vertigial region sparsely, setose; epicranial suture a thin line (Fig. 37B). Antennae slightly clavate, rather long, slightly extending back behind segment $3\left(O^{7}\right)$ or $2(+)$ when stretched dorsally; antennomeres $2=6>4=5=6>1=7$. Dorsum strongly and regularly convex, postcollum paraterga medium-sized, set at about upper $1 / 3$ of body height, broadly rounded anteriorly and acute dentiform caudally; lateral calluses smooth, thin, faintly sinuate and only slightly thicker in ozopore region, each callus delimited by a complete deep sulcus dorsally and a less distinct sulcus only in caudal half ventrally (Figs 37A, $38 \mathrm{~A}$ ); caudal corner of paraterga drawn behind rear tergal margin only in segments 16-19, nearly pointed. Ozopores lying inside a shallow ovoid pit ca $1 / 4$ of callus length in front of caudal corner (Fig. 38A). Body surface generally smooth and shining, only caudal halves of metaterga above paraterga slightly rugulose while metazonae below paraterga finely rugulose and microgranulate (Fig. 38A, B). A thin, grey, axial line visible through translucent tegument. Transverse metatergal sulci visible on segments $5-18$, thin and punctured at bottom, reaching bases of paraterga, a little weaker on segment 18 . Tergal setae short, mostly abraded, pattern traceable at least as $2+2$ in a pre-sulcus row. Stricture dividing pro- and metazonae rather narrow and deep, finely striolate at bottom dorsally (Fig. 38A, B). Pleurosternal carinae a small toothless lobe in segment 2 , visible as faint arcuate ridges in segments 3 and 4, wanting thereafter $\left(O^{7}\right.$,, ). Epiproct (Figs 37A, D, 38C) rather long, digitiform, truncate at apex, subapical lateral papillae very small and well removed from tip. Hypoproct (Fig. 38D) semi-circular, caudal 1+1 setae clearly separated, not borne on knobs, placed at caudal margin.

Sternites without modifications, very densely setose; cross-impressions weak; a single, roundly subtrapeziform, setose lobe between coxae 4 (Fig. 38E). All telopodites very densely setose and brush-like ventrally (Fig. 38A), $\sigma^{7}$ legs long and slightly crassate, ca 1.5-1.6 times as long as midbody height, prefemora not bulged laterally (Figs 37A-D, 38A); + legs considerably shorter and more slender; $O^{7}$ femur 1 with a very strong, setose adenostyle (Fig. 38F).

Gonopods (Figs 37E, 38F, G) complex, elongate and suberect; coxite long, subcylindrical, setose distoventrally; prefemoral part short, about half the length of femorite; the latter untwisted, slightly enlarged distad, distally or apically bearing a large, subtriangular, lateral process (o), a high, erect, lancetiform, ventral process (s) and a complex, dorsomesal outgrowth (dm) supplied with a knife-shaped retrorse process (k); solenophore (sph) high, subfalcate, set off basally from femorite by a clear sulcus, lamellar, deeply notched, acuminate, supporting a much shorter, flagelliform solenomere (sl).

ACKNOWLEDGEMENTS. I am extremely grateful to Jochen Martens (Mainz, Germany) and his collaborators for having most kindly sent me on loan their material for examination. Most of the colour pictures were skillfully taken by K. Makarov (Moscow, Russia), except for Figs 1 and 2 which were very generously provided upon my request by Nesrine Akkari and Edmond Schiller (both NHMW). Special thanks go to Alessandro Minelli (Padua, Italy) for his advice, as well as Kirill Mikhailov and Elena Kudryavtseva (both ZMUM) who helped me incorporate the ZMUM samples into the collection.

\section{References}

Attems C. 1936. Diplopoda of India // Memoirs of the Indian Museum. Vol.11. No.4. P.133-323.

Attems C. 1937. Myriopoda 3. Polydesmoidea I. Fam. Strongylosomidae // Das Tierreich. Lfg.68. S.I-XXII, 1-300.

Attems C. 1953. Myriopoden von Indochina. Expedition von Dr C. Dawydoff (1938-1939) // Mémoires du Muséum national d'Histoire naturelle, Série A, Zoologie. T.5. Fasc.3. P.133-230.

Bhakat S.N. 1987. Ecology of an Indian grassland millipede Streptogonopus phipsoni (Diplopoda: Polydesmoidea) // Journal of Zoology, London. Vol.212. P.419-428.

Carl J. 1932. Diplopoden aus Süd-Indien und Ceylon. 1. Teil. Polydesmoidea // Revue Suisse de Zoologie. T.39. No.17. S.411-529.

Golovatch S.I. 1990. Diplopoda from the Nepal Himalayas. The first Paradoxosomatidae (Polydesmida) // Spixiana. Bd.13. H.1. S.9-24.

Golovatch S.I. 1994a. Diplopoda from the Nepal Himalayas. Further Paradoxosomatidae (Polydesmida) // Senckenbergian biologica. Bd.73. H.1-2. S.163-182.

Golovatch S.I. 1994b. Diplopoda from the Himalayas. Two new Alogolykini (Polydesmida: Paradoxosomatidae) // Senckenbergian biologica. Bd.73. H.1-2. S.183-187.

Golovatch S.I. 1996. Diplopoda from the Nepal Himalayas. Review of the genus Orophosoma Jeekel 1980 (Polydesmida: Paradoxosomatidae) // Senckenbergian biologica. Bd.76. H.12. S.163-184.

Golovatch S.I. 2000. On several new or poorly-known Oriental Paradoxosomatidae (Diplopoda: Polydesmida), VII // Arthropoda Selecta. Vol.8. No.4. P.215-220 (for 1999).

Golovatch S.I. 2013a. On several new or poorly-known Oriental Paradoxosomatidae (Diplopoda: Polydesmida), XIII // Arthropoda Selecta. Vol.22. No.1. P.1-31.

Golovatch S.I. 2013b. On several new or poorly-known Oriental Paradoxosomatidae (Diplopoda: Polydesmida), XIV // Arthropoda Selecta. Vol.22. No.4. P.307-332.

Golovatch S.I. 2014. On several new or poorly-known Oriental Paradoxosomatidae (Diplopoda: Polydesmida), XVI // Arthropoda Selecta. Vol.23. No.3. P.227-251.

Golovatch S.I., Stoev P. 2013. The millipede family Paradoxosomatidae in the Philippines, with a description of Eustrongylosoma penevi sp.n., and notes on Anoplodesmus anthracinus Pocock, 1895, recorded in Malaysia and Sri Lanka for the first time (Diplopoda, Polydesmida) // Bidiversity Data Journal. Vol.1. P.1-17. http://dx.doi.org/10.3897/BDJ.1.e957

Hoffman R.L. 1961. Two new diplopod genera from western China (Polydesmida: Strongylosomatidae) // Annals and Magazine of Natural History, Ser.13. Vol.3. No.33. P.533-543.

Jeekel C.A.W. 1953. Two new Strongylosomidae from Indochina (Diplopoda, Polydesmida) // Beaufortia. Vol.2. No.29. P.1-8.

Jeekel C.A.W. 1956. Milliped miscellany - Part III // Beaufortia. Vol.5. No.51. P.73-99. 
Jeekel C.A.W. 1965. A revision of the Burmese Paradoxosomatidae (Diplopoda, Polydesmida) in the Museo Civico di Storia Naturale at Genoa (Part 1) // Tijdschrift voor Entomologie. Deel 108. Afl.5. P.95-144.

Jeekel C.A.W. 2009. Records of Paradoxosomatidae from New Guinea (Diplopoda, Polydesmida) // Myriapod Memoranda. Vol.11. P.75-82.

Likhitrakarn N., Golovatch S.I., Panha S. 2015a. The millipede genus Kronopolites Attems, 1914, with the description of a new species from Laos (Diplopoda: Polydesmida: Paradoxosomatidae) // ZooKeys. Vol.472. P.27-41.

Likhitrakarn N., Golovatch S.I., Panha S. 2015b. Two new species of dragon millipedes, genus Desmoxytes Chamberlin, 1923 , from Laos (Diplopoda: Polydesmida: Paradoxosomatidae), with redescriptions of all four species of Attems from Vietnam // Zootaxa. Vol.3931. No.4. P.483-504.
Nguyen D.A. 2011. A review of the millipede tribe Tonkinosomatini (Diplopoda: Polydesmida: Paradoxosomatidae) from Vietnam // Zootaxa. Vol.3036. P.58-68.

Nguyen D.A., Korsós Z.. 2011. A revision of the millipede genus Riukiupeltis Verhoeff, 1939 (Diplopoda, Polydesmida, Paradoxosomatidae) with comments on the status of related species // ZooKeys. Vol.156. P.25-40.

Nguyen D.A., Sierwald P. 2013. A worldwide catalog of the family Paradoxosomatidae Daday, 1889 (Diplopoda: Polydesmida) // Check List. Vol.9. No.6. P.1132-1353.

Shelley R.M. 2014. A summary of the milliped faunas of Pakistan, Bangladesh, and Kashmir (Arthropoda: Diplopoda) // Insecta Mundi. No.0368. P.1-7.

Responsible editor K.G. Mikhailov 